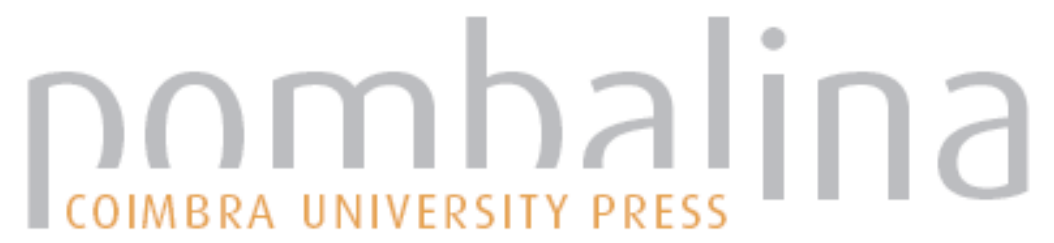

(8)

\section{Caminhos de Plutarco na Europa}

Autor(es): $\quad \begin{aligned} & \text { Pinheiro, Joaquim; Ferreira, José Ribeiro; Soares, Nair Castro; Marnoto, } \\ & \text { Rita }\end{aligned}$

Publicado por: Centro de Estudos Clássicos e Humanísticos; Imprensa da Universidade

URL

persistente: URI:http://hdl.handle.net/10316.2/2400

DOI: $\quad$ DOI:http://dx.doi.org/10.14195/978-989-8281-94-4

Accessed : $\quad$ 26-Apr-2023 12:43:00

A navegação consulta e descarregamento dos títulos inseridos nas Bibliotecas Digitais UC Digitalis, UC Pombalina e UC Impactum, pressupõem a aceitação plena e sem reservas dos Termos e Condições de Uso destas Bibliotecas Digitais, disponíveis em https://digitalis.uc.pt/pt-pt/termos.

Conforme exposto nos referidos Termos e Condições de Uso, o descarregamento de títulos de acesso restrito requer uma licença válida de autorização devendo o utilizador aceder ao(s) documento(s) a partir de um endereço de IP da instituição detentora da supramencionada licença.

Ao utilizador é apenas permitido o descarregamento para uso pessoal, pelo que o emprego do(s) título(s) descarregado(s) para outro fim, designadamente comercial, carece de autorização do respetivo autor ou editor da obra.

Na medida em que todas as obras da UC Digitalis se encontram protegidas pelo Código do Direito de Autor e Direitos Conexos e demais legislação aplicável, toda a cópia, parcial ou total, deste documento, nos casos em que é legalmente admitida, deverá conter ou fazer-se acompanhar por este aviso.

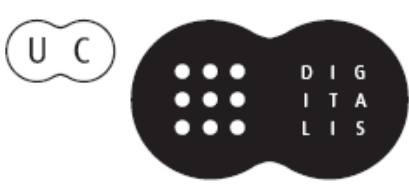




\section{Joaquim Pinheiro José Ribeiro Ferreira Nair Castro Soares Rita Marnoto}

\section{Caminhos de Plutarco na EUROPA}

$2^{a}$ EDIÇÃo REVISTA E AUMENTADA 


\section{JoAquim Pinheiro}

Universidade da Madeira

José Ribeiro Ferreira

Universidade de Coimbra

Nair Castro Soares

Universidade de Coimbra

Rita Marnoto

Universidade de Coimbra

\section{Caminhos de Plutarco na Europa}


Todos os volumes desta série são sujeitos a arbitragem científica independente.

Autores: Joaquim Pinheiro, José Ribeiro Ferreira, Nair Castro Soares, Rita Marnoto

Título: Caminhos de Plutarco na Europa

Editor: Centro de Estudos Clássicos e Humanísticos

IMPRENSA DA UNIVERSIDADE DE COIMBRA

EDIÇÃO: 2a revista e aumentada/2011 (1a/2008)

Coordenador Científico do Plano de Ediçấo: Maria do Céu Fialho

Conselho editorial: José Ribeiro Ferreira, Maria de Fátima Silva,

Francisco de Oliveira, Nair Castro Soares

Director técnico da COLECÇÃo / INVESTIGAdor RESPONSÁVEl PELO PROJECTO

Plutarco e os fundamentos da identidade EuRopeia: Delfim F. Leấo

Concepção gráfica e paginaçấo: Rodolfo Lopes e Nelson Henrique

Obra REALIZAda No ÂMbito DAS actividades da UI\&D

Centro de Estudos Clássicos e Humanísticos

Universidade de CoImbra

FACUlDADE DE LeTras

TeL.: 239859981 | FAX: 239836733

3004-530 CoImbra

ISBN: 978-989-8281-93-7

ISBN DigitAL: 978-989-8281-94-4

Depósito Legal: 331399/11

DOI: http://dx.doi.org/10.14195/978-989-8281-94-4

\section{Obra Publicada com o Apoio de:}

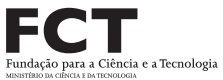

$\mathrm{POCI} / 2010$

(C) IMPRENSA DA UNIVERSIDADE DE COIMBRA

(C) Classica Digitalia Vniversitatis Conimbrigensis

(C) Centro de Estudos Clássicos e Humanísticos da Universidade de Coimbra

Reservados todos os direitos. Nos termos legais fica expressamente proibida a reprodução total ou parcial por qualquer meio, em papel ou em edição electrónica, sem autorização expressa dos titulares dos direitos. É desde já excepcionada a utilização em circuitos académicos fechados para apoio a leccionação ou extensão cultural por via de $e$-learning.

Volume integrado no projecto Plutarco e os fundamentos da identidade europeia e financiado pela Fundação para a Ciência e a Tecnologia. 


\section{ÍNDICE}

Prefácio 7

Joaquim Pinheiro, José Ribeiro Ferreira, Nair Castro Soares, Rita Marnoto

Plutarco no humanismo Renascentista em Portugal

Nair de Nazaré Castro Soares

Plutarco: o Regresso a Terras Itálicas

Rita Marnoto

Plutarco e o Conceito de Virtude nos Revolucionários FrANCESES

José Ribeiro Ferreira

Débito de Almeida Garrett a Plutarco

José Ribeiro Ferreira

A Tragédia Catão de Almeida Garrett.

Colheita em Plutarco

José Ribeiro Ferreira

Plutarco em Oliveira Martins: o Género Literário

E A Concepção Moral

Joaquim J. S. Pinheiro

Bibliografia 


\section{Prefácio}

Este volume de estudos sobre Plutarco, a que demos o título de Caminhos de Plutarco na Europa, é constituído por seis capítulos que contemplam outros tantos aspectos da recepção deste polígrafo grego na Europa, em especial em Itália, França e Portugal. No primeiro texto, "Plutarco no Humanismo Renascentista em Portugal", Nair de Castro Soares parte do conceito de humanitas, essência do movimento renascentista, e mostra a sua ligação com a célebre noção de 'doçura', que tanto relevo tem em Plutarco; mostra ainda que, ao longo dos tempos, da época medieval à modernidade, corriam colectâneas de sentenças e de apotegmas que muito contribuíram para a formação de uma mentalidade. O segundo trabalho, "Plutarco: o regresso a terras itálicas”, da autoria de Rita Marnoto, apresenta uma visão rápida da redescoberta das suas obras em Itália, desde a época medieval aos dias de hoje. Os três estudos seguintes, realizados por J. Ribeiro Ferreira, abordam o débito dos Revolucionários Franceses a Plutarco, no que concerne ao seu conceito de 'virtude' (terceiro estudo "Plutarco e 
o conceito de virtude nos Revolucionários Franceses”); o conhecimento que Almeida Garrett tinha da obra de Plutarco e a frequência com que a cita e utiliza os heróis como modelos (quarto capítulo "Débito de Garrett a Plutarco") e o aproveitamento que faz da Vida de Catão de Útica para a sua tragédia Catão (quinto capítulo "A tragédia Catão de Almeida Garrett. Colheita em Plutarco"). Por fim, o último estudo, "Plutarco em Oliveira Martins: o género literário e a concepção moral”, investiga a possível presença de Plutarco em outro autor português, Oliveira Martins; nele Joaquim J. S. Pinheiro encarregou-se de procurar pontos de contacto entre as Vidas de Plutarco e as biografias compostas por Oliveira Martins.

É evidente que não pretendemos, de modo algum, ser exaustivos nem dar uma ideia aproximada da totalidade da recepção de Plutarco nestes três países. Apenas quisemos dar cinco veios - Humanismo Renascentista, Itália, Revolucionários Franceses, Almeida Garrett, Oliveira Martins, e mesmo aí sem sermos exaustivos - do imenso caudal que foram a obra, o pensamento e os valores de Plutarco. Retenhamos na memória que foi considerado o "Educador da Europa".

Caminhos de Plutarco na Europa passa a ser livro que pode chegar às vossas máos e passa a ser vosso. E pretende despertar a vossa atençáo e curiosidade. Se o conseguir, todo ele sorrirá de satisfação.

Coimbra, Julho de 2011 Joaquim Pinheiro, José Ribeiro Ferreira, Nair Castro Soares, Rita Marnoto 


\section{Plutarco no humanismo renascentista EM PORTUGAL}

Nair de Nazaré Castro Soares 


\section{Plutarco no humanismo RenasCentista em PORTUgal}

Nair de Nazaré Castro Soares (Universidade de Coimbra)

Socrates Philosophiam e coelis deduxit in terras, Plutarchus introduxit in cubiculum, in conclaue, in thalamos singulorum. Erasmo $^{1}$

Jacqueline de Romilly, com a agudeza e a sensibilidade que póe em todos os seus trabalhos, dedica dois importantes capítulos a Plutarco, na sua obra $L a$ douceur dans la pensée grecque, ${ }^{2}$ onde afirma: «Vers la fin de la grande littérature grecque, on trouve, avec Plutarque, l'apogée de la notion de douceur. Chez lui, elle est partout; elle commande tout; et elle s'épanouit comme l'immage même d'un idéal de vie essentiellement grec». ${ }^{3}$

$\mathrm{O}$ próprio vocabulário da douceur - termo que exprime a qualidade humana de cada situação - é mais rico e mais completo do que em qualquer outro escritor, grego ou romano. ${ }^{4}$

${ }^{1}$ Erasmo 1961-1962: IV, 57-58.

2 J. de Romilly 1979: 275-307 (chap. XVI e XVII: «Plutarque et la douceur des héros»; «Plutarque et la douceur des sages»).

${ }^{3}$ Ibidem: 275. E prossegue a eminente professora (p. 292): «...la douceur évoquée par Plutarque s'inspire en certains cas de modèles [...]. Entre tous ces modèles, Plutarque choisit selon les circonstances; et leur combinaison même relève d'un mérite qu'aucun des auteurs précédents n'avait possédé - à savoir la finesse dans l'analyse psychologique».

${ }^{4}$ Ibidem: 274. É esta a conclusão a que chega, após o confronto que faz dos Moralia e das Vitae Parallelae de Plutarco com as obras 
Diversos, com efeito, são os estudos que analisam os termos, recorrentes na obra de Plutarco, que exprimem esta noção. Entre eles, surge frequentemente o de philanthrôpia, que se define como a virtude por excelência do homem civilizado e bem educado. ${ }^{5}$

Essência do movimento humanista, a humanitas - ponto de encontro entre tradição clássica e tradição cristã - abarca os conceitos de humanitas como sympátheia, de humanitas como pietas, de humanitas como charitas hominum, que não são mais do que variaçóes do conceito grego de philanthropia. ${ }^{6}$

Se não é possível encontrar no Renascimento qualquer doutrina filosófica comum, como observa Paul

de autores gregos e romanos, designadamente Platão, Aristóteles, Isócrates, Xenofonte, Cícero e Séneca. Este último tem tratados sobre os mesmos temas com os mesmos títulos, como é o caso do De ira e do De tranquilitate animi.

5 Ibidem: 274-307. Sobre a noção de philantrôpia - que ultrapassa o âmbito dos autores da Antiguidade greco-latina - nos autores cristãos, cf. Ibidem, «Douceur païenne et bonté chrétienne. I. La révolution du Christianisme».

${ }^{6}$ Ilustrativa, neste sentido, é a expressão de Guarino de Verona: Humanitas dicitur doctrina et erudicio unde vocantur studia humanitatis pro illa affectione quam habemus erga homines, quam Graeci uocant philanthropia, apud Gioacchino Paparelli (1973), Feritas, humanitas, diuinitas. L'essenza umanistica del Rinascimento, Napoli: 129. Paparelli demonstra (no cap. IX, p. 115-129), como os conceitos de doctrina e philanthrôpia se encontram intimamente ligados, na definição dos studia humanitatis, desde Petrarca e os humanistas do Quattrocento - Guarino de Verona, Leon Battista Alberti, Enea Silvio Piccolomini - aos primeiros humanistas europeus de Quinhentos, e entre eles Erasmo, fervoroso seguidor de Plutarco. 
Oskar Kristeller, ${ }^{7}$ premissa essencial de toda a cultura humanística, assente no aristotelismo ético-político e no designado «socratismo cristão», é que «o homem nasce para ser útil ao outro homem», ${ }^{8}$ pelo que o desenvolvimento dos dotes da ratio e do uerbum, que os distinguem dos outros animais, tem um alcance social. Os studia humanitatis são assim colocados ao serviço da "vita civile», em profunda implicação entre doctrina e societas. ${ }^{9}$

Não sem razão, Plutarco está entre os autores gregos que mais interesse despertaram no Renascimento. Houve já quem afirmasse que Cícero, Séneca, Plutarco preenchiam, no essencial, o quadro de uma humanitas orientada no sentido da vida social, ou melhor, de uma humanitas destinada a torna-se humanitas christiana. ${ }^{10}$

Considerado pelos humanistas desde Poliziano e Marsilio Ficino, a Erasmo e Fr. Luís de Granada como um moralista capaz de fazer a síntese entre a filosofia moral pagã e o verdadeiro cristianismo, ${ }^{11}$ foi assinalável

7 P. O. Kristeller 1955: 22. Em seu entender, o Humanismo da Renascimento, movimento cultural e literário, que na sua substância não era filosófico, teve importantes implicaçóes e consequências filosóficas, directamente relacionadas com o seu fundamental classicismo, que modelou o pensamento da época, em todos os domínios do conhecimento. Entre os autores da Antiguidade Clássica que considera favoritos do Humanismo Renascentista, conta-se Plutarco (cf. ibidem, e. g. p. 18 e 21).

${ }^{8}$ Vide e. g. Leon Battista Alberti 1843-1849: III. 92.

9 Sobre o empenhamento cívico do primeiro humanismo italiano e, na sua peugada, do movimento humanista europeu, vide e. g. J. Benthley 1987: 196-197 (maxime); P. Burke 1987 3a ed.

${ }^{10}$ Cf. O. Schottenloher 1972: II, 667-690 (maxime 684).

${ }^{11}$ Frei Luís de Granada refere-o explicitamente, no prefácio 
a influência de Plutarco no movimento geral das ideias renascentista.

O Humanismo, que se centra no saber e nos valores da Antiguidade apoiados nos textos originais dos seus autores, criteriosamente depurados e estabelecidos pela rigorosa filologia, vai conhecer e apreciar Plutarco, nos seus escritos morais, nos Moralia, de grande variedade e amplitude temática, e nas Vitae Parallelae, as suas biografias de homens ilustres, gregos e romanos, sobre os quais estabelece o páragon.

Conhecido na Idade Média através do tratado pseudo-plutarquiano Institutio Trajani, ${ }^{12}$ e redescoberto, na sua obra completa, nos finais do Trecento, ${ }^{13}$ é sobretudo a partir do século XV que o escritor de Queroneia vai merecer ediçốes e traduçóes latinas da autoria de humanistas de renome, e nas diferentes línguas vulgares, nos quatro cantos da Europa culta. ${ }^{14}$

da sua Collectanea moralis philosophiae (Olyssipone, 1571). Na sua Ecclesiasticae rhetoricae siue de ratione concionandi libri sex (Olyssipone, 1576) aduz os testemunhos de insignes autores e, em primeiro lugar, «Plutarco, o mais grave de todos os filósofos». Cf. trad. espanhola: L. De Granada 1945: III, 494.

${ }^{12}$ Esta obra - que segundo a tradição é o resultado do magistério de Plutarco junto do imperador Trajano -, encontrada no século XII, apresenta a orgânica do estado da Antiguidade, com um ténue revestimento cristáo, e aponta no sentido da secularização. Cita-a Frei António de Beja, na sua Breve Doutrina e ensinança de príncipes, através de Vincent de Beauveais. Vide a este propósito, Nair N. Castro Soares 1994: 60 e 68.

${ }^{13}$ Vide August Buck 1980: 157 e sqq.

${ }_{14}$ Entre os tradutores de grego para latim, encontram-se humanistas famosos como Guarino de Verona, Francesco Barbaro, Leonardo Bruni, Francesco Filelfo, Coluccio Salutati, Bartolomeo Platina, Angelo Decembrio, Niccolò Perotti, Desidério Erasmo. 
Entre estas, dadas as afinidades culturais e políticas de Portugal e Castela, merecem especial relevo as traduçóes castelhanas quatrocentistas de Alonso de Palencia e Carlos de Aragón, príncipe de Viana e, no século XVI, as de Diego Gracián de Alderete. ${ }^{15}$

Plutarco foi um dos autores mais frequentemente traduzidos e editados, mais lidos e imitados no Renascimento. ${ }^{16}$ A Guarino de Verona se deve a tradução do tratado pseudo-plutarquiano, o Peri paídôn agôgês, conhecido pelo título latino De liberis educandis, com importância marcante na divulgação da moderna pedagogia humanista - a ponto de ser considerado conjuntamente com a obra de Quintiliano verdadeiro vademecum de todos os escritores pedagógicos do Renascimento. ${ }^{17}$

Em línguas vulgares, além das traduçôes para castelhano, refiram-se as traduçóes de Pedro Crinito para italiano, de Thomas Elyot e Thomas North para inglês, de Jacques Amyot para francês, entre os principais. Sobre as traduçôes das obras de Plutarco, vide Nair N. Castro Soares 1994: 86; 87; 90; 92-93; 100; 112; 115; 116; 122; $143 ; 145 ; 149 ; 160 ; 167 ; 226-228 ; 237$.

${ }^{15}$ Alonso de Palencia (1423-1492) foi pajem de D. Alonso de Cartagena e de Bessarión, em Itália, onde estudou grego com Jorge Trebizonda. D. Alonso de Cartagena, futuro bispo de Burgos, traduziu o primeiro livro do De inuentione de Cícero para o nosso rei D. Duarte e foi diplomata em Portugal de 1421-1427. Vide a este propósito, Nair N. Castro Soares 1994: 90.

${ }_{16}$ Vide V. R. Giustiniani 1961: 3-62; R. Aulotte 1965. Augustin Redondo (1976: 623) refere Plutarco como «l'auteur peut-être le plus lu au XVI ${ }^{e}$. siècle»; e P. O. Kristeller (1955: 18 e 21) considera-o um dos autores favoritos do Renascimento.

${ }^{17}$ Sáo estas as palavras de G. B. Gerini 1896: 274: «Tra le molteplici operette di Plutarco, tradotte dal Guarino, è notevole l'opuscolo Intorno all'educazione dei fanciulli, che fece latino fra il 1410 ed il 1411, dedicandolo ad Angelo Corbinelli, il quale scritto, 
Plutarco foi objecto de grande apreço e efusivos louvores. São reveladoras, neste sentido, as palavras de Rabelais, quando apresenta Gargântua, na célebre carta a Pantagruel, a deleitar-se com a leitura dos diálogos de Platão e "les Moraulx de Plutarche" e a recomendá-la a seu filho. ${ }^{18}$

A mensagem espiritualizada de Plutarco, posta ao serviço da moral natural e do relacionamento, em termos afectivos, entre os membros de uma comunidade, encontra-se na Utopia de Thomas More. Os seus habitantes, leitores de Plutarco, tinham uma constituição modelada pelas leis de Licurgo, em Esparta, e adoravam uma deusa, Mytra - o nome de Mytra amplifica o sentido misterioso e sobrenatural do ser divino - aparentada com a divindade persa referida por Plutarco em De Iside et Osiride. ${ }^{19}$

Guillaume Budé modela a sua Institution $d u$ prince sobre os Apophtegmata de Plutarco. ${ }^{20}$

Frei António de Guevara, no Relox de principes - editado em Lisboa em 1529 por Germáo Galhardo, com privilégio de D. João III, segue Plutarco como principal fonte. ${ }^{21}$

António de Nebrija, em De liberis educandis, Thomas Elyot, em The governour, Jacopo Sadoleto, em De liberis recte instituendis, dão testemunho da

unitamente all'opera di Quintiliano, divenne il vademecum di tutti gli scrittori pedagogici del Rinascimento»

${ }^{18}$ François Rabelais 1959: 42.

${ }^{19}$ André Prévost 1978: 119-120; 541; 590; 613 e 715-716.

${ }^{20}$ Cf. Claude Bontems et alii 1965: 9-10.

${ }^{21}$ Augustin Redondo 1976: 545. 
presença constante de Plutarco, modelo pedagógico do humanismo europeu - o "Educador da Europa". ${ }^{22}$

Montaigne saúda nestes termos a tradução das Oeuvres morales de Plutarco, que Amyot acabava de publicar (Essais, II, 4): «... mais surtout je lui sais bon gré d' avoir su trier et choisir um livre si digne et si à propos, pour en faire présent à son pays. Nous autres ignorants étions perdus, si ce livre ne nous eût relevés du bourbier: sa merci (grâce à lui) nous osons à cette heure et parler et écrire; les dames en régentent les maîtres d'école; c' est notre bréviaire». ${ }^{23}$

Encarregado da educação dos dois últimos príncipes Valois, ${ }^{24}$ Amyot traduziu em 1559, com dedicatória a Henrique II, as Vies des hommes illustres e em 1572 as Oeuvres morales que dedica a Carlos IX. A Amyot e à lição de Plutarco se deve a reputação de ter sido este rei educado "fort catholiquement", assim como a do seu "bon, orné et éloquent parler". ${ }^{25}$

É contudo Erasmo, entre todos os autores desta época, aquele cuja obra reflecte de forma mais profunda, temática e formalmente, a lição do autor de Queroneia. É que aos muitos escritos de Erasmo - além da preocupação moral de fornecer modelos de conduta

${ }^{22}$ Vide Elio Antonio de Nebrija 1981 (ed.); Thomas Elyot 1880 (ed.); Jacopo Sadoleto 1855 (ed.).

${ }^{23}$ Cf. Pierre Villey 1912: 13-14.

${ }^{24}$ Vide A. Adler 1975: 131-138.

${ }^{25}$ Vide Ferdinand Buisson 1887: 2435-2436. Para se fazer uma ideia do empenho dos humanistas pela obra de Plutarco, pode consultar-se a bibliografia apresentada por Robert Aulotte 1971: 243-245. 
ao homem comum e ao homem de estado - preside também o ideal pedagógico-didáctico da formação integral do homem, na sua dimensão humana, espiritual e metafísica, numa permeabilidade intrínseca entre studia humanitatis e studia diuinitatis. Elucidativas, neste sentido, são estas palavras do Humanista de Roterdão: Bonae litterae reddunt homines; philosophia plusquam homines; theologia reddit diuos. ${ }^{26}$

Erasmo não se cansa de proclamar a grandeza do moralista grego, com quem profundamente se identifica, nos interesses comuns, nas ideias pedagógicas, éticopolíticas, de moral individual e social, na sensibilidade e gostos estéticos afins.

A expressão do apreço de Erasmo por Plutarco - a par da confessada dívida em relação à sua obra - surge a cada passo, a abrir os Adagia, os Apophthegmata, e na Institutio principis christiani. Nesta obra, o humanista de Roterdão coloca Plutarco em primeiro lugar, entre os autores clássicos que aconselha ao príncipe, não só pelos ensinamentos dos seus tratados - nada pode existir de mais santo - como pelo exemplo da sua vida. ${ }^{27}$

Compreende-se assim que Plutarco, a par de Quintiliano - logo seguidos de Diógenes Laércio - seja também a principal fonte do tratado de Erasmo que se destina à educação da primeira infância, o De pueris instituendis, ${ }^{28}$ cuja recepção é enorme em toda a Europa.

${ }^{26}$ Erasmo: L.B., IV, 628 D.

${ }^{27}$ Erasmo: L.B., IV, 587 F. Vide também a este propósito, Pierre Mesnard 1977: 97.

${ }^{28}$ Vide J.-C. Margolin 1966: 96-100. 
É na obra de Plutarco e na de Diógenes Laércio, editadas por vezes conjuntamente ${ }^{29}-$ sem esquecer as de Suetónio, Aulo Gélio ou Valério Máximo - que os humanistas, satisfazem o interesse pela Antiguidade, pelo pulsar concreto da vida das grandes figuras históricas, pela profundidade do seu pensamento, e colhem os exempla que enriquecem a sua inventio. ${ }^{30}$

Em Portugal, com a introdução do Humanismo, nos finais do século XV, designadamente a partir de Cataldo Parísio Sículo, que chega à corte de D. João II em 1485, Plutarco faz parte do corpus auctorum, lido e assimilado pelos nossos humanistas e integra a cultura literária dos nossos escritores da época de Quinhentos.

Já antes, num proto-humanismo liderado pelos Príncipes de Avis, a lição de Plutarco se fizera sentir, entre nós, por influência dos autores do Quattrocento italiano. ${ }^{31}$

${ }^{29}$ Vide a edição conjunta de escritos de Plutarco e Diógenes Laércio na B.N. Paris (cota: Z. 17588): Apophthegmata graeca regum et ducum, philosophorum item aliorumque... ex Plutarco et Diogene Laertio. Cum latina interpretatione. Loci aliquot in graeco contextu emendati fuerunt... . s. 1., H. Stephanus, 1568.

30 Sobre o interesse das obras de carácter biográfico no Renascimento, P. O. Kristeller (1962: 392) pronuncia-se, nestes termos: «Nel campo letterario, la letteratura biografica e quella autobiografica ebbero una fioritura raramente raggiunta in altre epoche».

31 Se é possível aludir a um proto-humanismo na corte de Avis, a influência humanista é bem mais notória do ponto de vista ideológico do que do ponto de vista estético-filológico, onde haveria ainda largo caminho a percorrer. Pier Paolo Vergerio, que sabia grego e tivera Manuel Crisolara por primeiro mestre, recolhe, na sua obra 
A preferência por Plutarco reflecte-se já na obra de Vasco de Lucena, um português ao serviço da duquesa Isabel, filha de D. João I, na corte de Borgonha do século XV, com estreitas relaçôes com o humanismo italiano, a que também nós não fomos alheios. A Vasco de Lucena se deve a Histoire d'Alexandre de Quinto Cúrcio, completada nas lacunas do original sobretudo pela Vida de Alexandre de Plutarco, segundo a versão latina de Guarino de Verona. ${ }^{32}$

Expressiva, entre nós, é a tradução "em linguajem" - realizada por Vasco Fernandes de Lucena, na corte de Avis, a pedido do Infante D. Pedro -, do tratado pedagógico, com nítida influência de Plutarco, 'Sobre os nobres costumes e os estudos liberais da juventude', De ingenuis moribus et liberalibus studiis adulescentiae (1402). É este o primeiro tratado pedagógico, na verdadeira acepção da palavra, quer pelo teor prático da

pedagógica, os ensinamentos de Plutarco - do tratado pedagógico e das restantes Obras morais, bem como das Vidas Paralelas, de que cita a Vida de Mário. Sabe-se que a traduçáo latina de Guarino de Verona do De liberis educandis de Plutarco data de 1410, apesar de ter sido publicada em 1497. É conhecida, no entanto, a ampla divulgação, nesta época, dos originais manuscritos, por vezes com implicaçôes a nível de autoria, como é o caso da obra De regnandi peritia de Agostinho Nifo, inspirada no manuscrito de Il principe de Maquiavel). Sobre a importância de Plutarco no Quattrocento italiano, vide G. B. Gerini 1896; Eugenio Garin 1958: 307-503 e 725-726.

${ }^{32}$ Além de presente nas Vidas paralelas, a figura de Alexandre é ainda tema de dois opúsculos de Plutarco, que, dentro da tradiçấo retórica da declamação, discutem os conceitos de tyche e aretê, que se interpenetram e sobrepóem, sem verdadeiramente se oporem, no grande herói macedónio, como exemplum. Vide Nair N. Castro Soares 1994: 87; M. R. Cammarota 1992: 105-124; M. R. Cammarota 2000: 69-86; M. R. Cammarota 2002: 147-166. 
sua doutrina, quer pela real divulgação que conheceu em toda a Europa. ${ }^{33}$

$\mathrm{Na}$ verdade, de grande significado na definição dos nossos ideais culturais, nesta época, é a influência directa da Itália em Portugal, pelo menos a partir do início do século XIV. Conhecida é a presença de letrados portugueses em Itália entre 1350 e 1450 e o papel desempenhado pelo abade D. Gomes, geral da ordem camalduense, núncio e visitador apostólico dos mosteiros de Portugal, figura de grande prestígio em Florença. ${ }^{34} \mathrm{Na}$ abadia de D. Gomes, futuro prior de Santa Cruz de Coimbra, fora D. Pedro recebido por ocasião da sua visita a Itália. ${ }^{35}$

A importância que o livro de Vergério teve no Renascimento português advém-lhe não só da recepção

${ }^{33}$ Vide P. P. Vergerio 1918 (ed.). Nas suas viagens pelos centros políticos, culturais e religiosos da Europa (1425-1428) - Inglaterra, Flandres, Hungria, Itália (Veneza, Pádua, Florença e Roma) - o Infante D. Pedro relaciona-se com humanistas italianos, tais como Ambrogio Traversari, que lhe dedica a tradução do De Prouidentia de S. João Crisóstomo, e com Pier Paolo Vergerio (1370-1444), que conheceu na corte de Segismundo da Hungria. $\mathrm{O}$ tradutor deste tratado, Vasco Fernandes de Lucena - distinto de Vasco de Lucena, anteriormente referido - foi um dos tradutores mais activos dos autores clássicos, ao serviço dos ideais pedagógicos dos príncipes de Avis. Desempenhou ainda funçóes de embaixador do rei D. Duarte (ao Concílio de Basileia e junto do Papa Eugénio IV) e do rei D. João II (junto do papa Inocêncio VII).

${ }^{34}$ Vide Davide Bigalli 1989: 65-117.

35 O Infante D. Pedro, nas suas viagens pela Europa (14241428) - Inglaterra, Flandres, Hungria, Itália (Veneza, Pádua, Florença e Roma) - relaciona-se com humanistas italianos, tais como Ambrogio Traversari - que lhe dedica a tradução do De Prouidentia de S. João Crisóstomo - e Pier Paolo Vergerio (13701444), que conheceu na corte de Segismundo da Hungria. 
que teve entre nós, a partir do século XV, mas sobretudo do facto de definir os ideais e o programa da educação humanística. ${ }^{36}$ Dedicado a Ubertino de Carrara, este tratado destinava-se à educação de jovens pertencentes a famílias principescas ou nobres. O ideal de renovação do espírito de Roma presidiu à elaboração desta obra, em que sobressai a inspiração dos clássicos, Cícero e Séneca e os recém redescobertos Quintiliano e Plutarco - intérprete este do pensamento grego dos autores do século IV e da filosofia da época helenística, com admirável sincretismo. ${ }^{37}$

A partir da obra de Vergerio, a influência de Plutarco está amplamente documentada em toda a tratadística pedagógica, de inspiração clássica, designada por educação moderna, desde os autores do Quattrocento, como Maffeo Vegio (De educatione liberorum clarisque eorum moribus), Enea Silvio Piccolomini (De educatione liberorum), Leon Battista Alberti (Della famiglia), Francesco Filelfo (De morali disciplina), Diomede Carafa (Dello optimo cortesano), entre outros. Carafa precede e anuncia Il Cortegiano de Baldassare Castiglione e Il Galateo de um Giovanni della Casa, autores que, no

${ }^{36}$ Vide, maxime, os caps. 26-32 do De ingenuis moribus.

37 Os princípios ético-pedagógicos, que desde a sofística e a partir de então, designadamente em Isócrates, Xenofonte, Platão, Aristóteles, o educador de Alexandre, aos autores latinos, e entre eles Cícero - fonte de informação das várias escolas de filosofia grega e modelo humanista de pensamento ecléctico, em que se harmonizam eloquência e sabedoria - serviram de referência a Plutarco bem como a Quintiliano e aos autores da Segunda Sofística, com seus ideais pedagógicos predominantes. Vide G. Anderson 1993. 
século XVI, se ocuparam da arte e da ciência do bem viver cortesanesco, dentro de uma ética que Plutarco actualizara, a partir da famosa edição aldina dos Moralia, no original grego, intitulada Opuscula (1509). É esta a edição de que se serve Erasmo para elaborar a tradução latina froebeniana (em 1514) e a que sairia a lume, mais completa, nos prelos venezianos dos herdeiros de Aldo Manúcio (em 1518) - que no ano seguinte editariam, no original grego, as Vitae parallelae. ${ }^{38}$

Marco definitivo da orientação das ideias pedagógicas da educação moderna são os ensinamentos do De liberis educandis, que abre os Moralia, sobre a criação, instrução e formação dos filhos, desde a sua concepçáo à sua emancipação, quando contraem casamento, verdadeiros topoi nos tratados humanistas ${ }^{39}$.

Plutarco, defensor e representante de uma moral social nova, contesta valores da cultura grega como a pederastia e a homossexualidade e vai colocar, como centro do casamento, o amor conjugal, de que faz depender a feliz convivência entre os esposos, a condição

${ }^{38} \mathrm{O}$ Perì Paídôn agôgếs, traduzido em latim pela primeira vez em finais do século XV por Guarino de Verona, conhece uma ediçáo conjunta (Paris, 1454) com o De ingenuis moribus de Pier Paolo Vergério: B.N. Paris - cota: /Rés. R. 1566. Em Veneza, os prelos de Aldo Manúcio (1494-1515) e seus herdeiros vão conhecer um notável labor editorial, com a supervisão de humanistas como Erasmo, que neles publica os seus célebres Opera, em 1518.

39 Outros opúsculos, com ensinamentos importantes para a educação e formação do carácter, e fonte de inspiração frequente dos humanistas, são: o De audiendo, ou De recta ratione audiendi, o De audiendis poetis e o De musica. Além de escritos como An uirtus doceri possit, De uirtute morali, De uirtute et uitio, De uitioso pudore, que se adequam admiravelmente à mundividência humanista. 
da mulher face ao marido. ${ }^{40}$ É este um dos aspectos mais marcantes da modernidade do pensamento de Plutarco, nos Moralia: a importância concedida à instituição do casamento, à reciprocidade de deveres dos cônjuges, à família, pais e filhos, em que se assume como princípio universal a afectividade, a comprensão, a doçura semelhante à caritas Paulina -, do maior alcance no relacionamento mútuo e na educação dos filhos. ${ }^{41}$

Já no Leal Conselheiro, da primeira metade do século XV, D. Duarte dedica alguns capítulos à reflexão sobre o amor e o casamento. Além da sua experiência pessoal - o mais interessante desta obra - não faltaram ao monarca referências literárias. ${ }^{42}$ Não poderemos deixar de lembrar que o De regimine principum de Egídio Romano, que fazia parte da biblioteca real e era

${ }^{40}$ Expressivos são os opúsculos de Plutarco, como: Coniugalia praecepta, Mulierum uitutes, Amatorius, Amatoriae narrationes, De amore prolis, Consolatio ad uxorem, De fraterno amore.

${ }^{41}$ Entre as obras de Plutarco que abordam mais directamente esta matéria refiram-se - em tradução latina, veículo privilegiado da sua divulgação, no Renascimento - Amatorius, onde enaltece a importância do amor conjugal; os Coniugalia praecepta, conselhos sobre a vida conjugal, dirigidos a dois dos seus discípulos que vão casar, Eurídice e Poliano; a Consolatio ad uxorem, por ocasião da morte de uma filha, em que alia a serenidade filosófica a uma singular ternura pela esposa; o De amore prolis e o De liberis educandis, em que os filhos são o principal objecto; e, enfim, sobre o amor fraternal, o De fraterno amore. Isto sem esquecer muitas das suas Vitae, que apresentam exemplos históricos dos valores enunciados nos Moralia.

${ }^{42}$ Cf. os capítulos RIIII-RVIII. Vide Mário Martins: 1983: 187206; Paulette Demerson 1983: 483-500; M. Lurdes C. Fernandes 1984: 133-194. 
obra de leitura privilegiada na corte de Avis, se debruça no Livro II sobre a família: a primeira parte sobre a vida matrimonial e a segunda sobre a educação dos filhos.

Durante a Idade Média, descuraram-se as virtudes naturais e espirituais da união conjugal, pôs-se em causa a legitimidade do casamento como sacramento, considerado benéfico no plano moral e social, mas bem inferior ao estado religioso, à vida monástica. ${ }^{43}$

A consolidação progressiva da autoridade do estado, sobretudo a partir do séc. XV, e as perturbaçóes ocasionadas pela importância conferida ao poder económico como factor de ascenção social contribuíram para a revalorização do casamento e da família, célula de base da sociedade. Face a uma economia em expansão, em que o dinheiro desempenha um papel primordial, impóe-se o regresso aos valores tradicionais, à dignificação do casamento, ao fortalecimento dos laços familiares, sem os quais a ordem social não pode ser mantida. Exemplos significativos desta atitude são os tratados do Quattrocento italiano, profundamente influenciados pela obra de Plutarco: o De re uxoria de Francesco Barbaro, composto em 1415-1416, e sobretudo Della famiglia, de Leon Battista Alberti, de cerca de 1440 , que teve grande e rápida divulgação, a julgar pela influência que teria tido na Celestina. ${ }^{44}$

É no século XVI que ganha actualidade a problemática do casamento (An sit nubendum?), que constitui um dos debates favoritos das escolas dos

\footnotetext{
${ }^{43}$ Lucien Febvre 1944: 314; Émile V. Telle 1954: 409-410.

${ }^{44}$ Vide Marcel Bataillon 1961; J. A. Maravall 1964.
} 
sofistas, que surge no Organon de Aristóteles, nos livros das Categoriae uel praedicamenta - sob as espécies do último modo do praedicamentum "De habere» - e figura como exemplum nos Progymnasmata de Hermógenes e de Aftónio, muito divulgados e apreciados, no Renascimento. ${ }^{45}$

Tema eterno, pelas suas implicaçóes múltipas no domínio do humano, o casamento tornou-se um dos assuntos mais vezes abordado pelos homens de Quinhentos. Neste sentido, reveste-se de particular importância a obra de Erasmo que, sobretudo a partir do Enchiridion militis christiani, muito contribui para a secularização da piedade cristã e consequentemente do estado matrimonial. ${ }^{46}$ Diversas são as obras em que o Humanista de Roterdáo aborda o tema do casamento, designadamente o Encomium matrimonii, de 1518, os Colloquia matrimoniais, que datam de 1523 - os que apresentam ensinamentos pré-nupciais, Virgo misogamos, Virgo poenitens, Proci et Puella e o célebre Uxor mempsigamos siue coniugium, que contém instruçốes para os esposos - e a Institutio christiani matrimonii de 1526.

45 Vide Gérard Defaux 1973): 212-214. Assinalável é a importância de que se revestem os Progymnasmata, no ensino da retórica e da diléctica, e na construçáo do discurso dos autores do Renascimento. Basta lembrar Rudolfo Agricola - tradutor dos Progymnasmata de Aftónio - Erasmo, ou Guillaume Budé, ilustres humanistas do primeiro humanismo europeu, influenciados pela tradição patrística e bizantina. Vide R. Naudeau 1952: 264-285; Lisa Jardine 1988: 38-57 (em especial p. 48 e sqq.); J. Chomarat 1981: 520; A. Michel 1984: 19-29; J. Ijsewijn 1973: 329-342.

${ }^{46}$ Vide Marcel Bataillon 1966: 287. 
Além da produção erasmiana, que difundiu e vulgarizou um paulinismo matrimonial que actualiza a mensagem de Plutarco, outras obras de diferentes autores se lhe seguiram. Lembre-se, entre os mais célebres, Luís Vives com os seus tratados De institutione foeminae christianae, de 1523 , e De officio mariti, de 1529.

Muitas foram as traduçóes e adaptaçóes destas obras - por exemplo, na vizinha Espanha - ou que delas receberam influência. ${ }^{47}$

Por toda a Europa, onde era alarmante o número de filhos naturais e de casamentos clandestinos, se generaliza o gosto por esta literatura sobre o casamento, no seu aspecto teológico, jurídico, institucional e humano, inspirada na Sagrada Escritura, no direito romano - o romanismo impóe-se como esteio da secularização -, nos tratados clássicos de economia doméstica de Aristóteles e de Xenofonte e nos preceitos matrimoniais de Plutarco. ${ }^{48}$

${ }^{47}$ Exemplo da recepção destas obras é o Relox de príncipes de Fr. Antonio de Guevara. Vide Augustin Redondo 1976: 623-624.

Entre as traduçóes castelhanas de Erasmo contam-se o Colloquio de Erasmo intitulado Institución del matrimonio christiano de Diego Moejón (1527), versão do Colóquio erasmiano Uxor mempsigamos; e o Sermón en loor del matrimonio, de Juan de Molina, composto a partir do Encomium matrimonii (1528).

O tratado de Vives De institutione foeminae christianae é traduzido por Juan Justiniano, com o título Libro llamado Institución de la muger christiana (1528).

${ }^{48}$ Vide L. Guillerm, Jean Pierre Guillerm et alii (1983), Le miroir des femmes I. Moralistes et polémistes au XVIe siècle. Lille. Entre todas são de referir as obras de Tiraqueau, De legibus Connubialibus (desde 1513), de Nevizano, Sylvia nuptialis (1521), as de H.-C. 
O casamento foi tema de debate alargado, desde a primeira metade do século XVI, ${ }^{49}$ até aos seus finais, em tempos da Contra-Reforma, de que são exemplo os diálogos filosóficos sobre a vida civil de G. B. Giraldi Cinzio - que integram os Ecatommiti, as cem novelas que serviram de fonte de inspiração a Shakespeare que mereceram tradução francesa de Gabriel Chappuys (Paris, 1583). ${ }^{50}$ Sobre os Diálogos de Cinzio dirá J. P. Guillerm: «Seul Giraldi, sous le couvert d'une réunion élégante, s'efforce dans le contexte post-tridentin de proposer un moralisme tout imprégné de la sagesse d'un Plutarque». ${ }^{51}$

Em Portugal, inserem-se nesta tendência moralizadora o Espelho de casados do Doutor Joáo de Barros, o Casamento perfeito de Diogo Paiva de Andrade, e o tratado - a que acresce a componente jurídica - Dos priuilegios \& praerogatiuas $\tilde{q}$ ho genero feminino tẽ de Rui Gonçalves. ${ }^{52}$

Agrippa de Nettessheim, De sacramento matrimonii (1526) e De nobilitate et praecellentia foeminei sexus (1529).

${ }^{49}$ É sobretudo a partir de 1520, data em que Lutero publicara O cativeiro babilónico da Igreja, que muitas obras se debruçaram sobre o sétimo sacramento. Vide Emile V. Telle 1954: 296

${ }^{50}$ Gabriel Chappuys 1583.

${ }^{51}$ Cf. L. Guillerm, Jean-Pierre Guillerm et alii 1983: 42. O próprio Concílio de Trento se pronunciou sobre a disciplina e a atéliturgia do casamento cristáo. Cf. Ibidem: 115-124, a tradução francesa quinhentista por Gabriel Du Préau dos Decretos e Cânones do Concílio de Trento, respeitantes ao casamento.

${ }^{52}$ Vide Espelho de casados pelo Doctor João de Barros (1540): 1874 (ed.); Diogo Paiva de Andrade (1630), Casamento perfeito em que se contem advertências... para viverem os casados em quietação... \& muitas hystorias, \& acontecimentos... dos tempos antigos, \& modernos... com 
Curioso é notar que o Espelho de casados do Doutor João de Barros reflecte os gostos retóricos da época e apresenta-se, formalmente, como um exemplo de debate An sit nubendum?

A primeira parte contém «Doze razóes que disfavorecem o casamento as quaes se poserom aqui pera se reprouarem: por mayor favor dele». Na segunda parte «o autor prova por Doze Razóes evidentes e muytos fundamentos quam excelente e proveitoso e necessário seja o casamento».

A temática do casamento, na nossa literatura, a exprimir a mentalidade do tempo, está presente nas obras de teatro - em alguns autos de Gil Vicente, nas comédias de Jorge Ferreira de Vasconcelos, nos autos de Camóes -, ou ainda mais explicitamente, porque repositório de preceitos, na Collectanea moralis philosophiae de Frei Luís de Granada. Neste livro de sentenças, a matéria apresenta-se seriada, segundo os diferentes temas - series locorum. ${ }^{53}$ Dividida em três partes, a segunda é dedicada aos opúsculos morais de

varias sentenças, \& documentos de autores gregos, \& latinos...Lisboa, Jorge Rodrigues; Rui Gonçalves, Dos priuilegios \& praerogatiuas $\tilde{q}$ o genero feminino tẽ por dereito comũ \& ordenaçôes do Reyno mais que ho genero masculino. Apud Iohanne Barrerium Regium Typographum, Anno Domini 1557.

${ }^{53}$ Vide Collectanea moralis philosophiae, in tres tomos distributa: quorum primus selectissimas sententias ex omnibus Senecae operibus, Secundus ex moralibus opusculis Plutarchi, Tertius clarissimorum principum \& philosophorum insigniora apophthegmata, hoc est, dicta memorabilia complectitur. Collectore F. Ludovico granateñ monacho Dominicano. Olisippone, Excudebat Franciscus Correa, Serenis S. Cardinalis Iff. Typogra. 1571. 
Plutarco, e estende-se por cerca de trezentas páginas (497-787).

Entre as reflexões, feitas no prefácio desta obra, que servem para enaltecer a grandeza moral da mensagem dos autores clássicos e encarecer a utilidade da sua leitura, surge o elogio de Plutarco, que termina nestes termos: «Nenhum destes erros se encontra em Plutarco, mas tudo nele está como que de acordo com a luz da razão e da natureza mais recta: talvez porque o Evangelho de Cristo, brilhando ao longe no século em que ele vivia, acrescentava ao espírito humano uma maior luz de verdade». ${ }^{54}$

$\mathrm{Na}$ segunda parte desta colectânea, dedicada à mensagem de Plutarco (p. 497-787), têm relevo temas como o casamento, o relacionamento entre os cônjuges, a educação dos filhos, ou outros respeitantes à moral individual ou social. ${ }^{55}$ A auctoritas de Plutarco e o

${ }^{54}$ Ibidem: Horum /errorum/ nibil in Plutarcho deprehendes: sed omnia fere purgatissimae rationi, et naturae lumini consentanea: fortasse quoniam Euangelio Christi eius seculo latius coruscante, maior humanis mentibus ueritatis lux addita esset.

${ }^{55}$ Vide e. g. Matrimonium (p. 518; 548); Viret uxor-Matrimonium (p. 518-520; 548); Pater, flius, filiorum educatio (p. 520-527); educatio filiorum (p. 520; 510; 715); Pater (p. 520; 613; 510); Adolescentia, senectus (p. 517); Obseruantia in maiores (p. 666); Verecundia siue pudor (p. 737); affectus et passiones animae (p. 514); Dilectio erga inimicos (p. 587, 600; 630); adulatio (632; 567; 586; 548; 609); Hipocrisis (p. 765); Beneuolentia ciuium captanda et maleuolentia fugienda (p. 621); Virtus quomodo facilis (p. 578); Hominis dignitas (p. 513); Quies siue tranquillitas animi (p. 725; 580). Note-se que todos estes loci apresentam a mensagem de Plutarco, colhida nas diferentes obras, pelo que os Moralia e as Vitae são aproveitados indistintamente. Assim, por exemplo, a educação dos filhos (p. 520-527) apoia-se sobretudo no De liberis educandis, mas em grande medida nos costumes dos Lacedemónios, veiculados pela vida de Licurgo. Na Collectanea se 
fácil acesso à sua mensagem equiparam esta obra, pelo menos junto de um público mais erudito, aos tratados especificamente compostos sobre o assunto, pese embora a divergente forma discursiva.

Todas estas obras, apesar de enfoques variados, apresentam, a nível da doutrinação ou da linguagem, das imagens e das sententiae, aspectos comuns que têm por fonte Plutarco. É que muitos dos preceitos e ideias que Plutarco defende são o resultado da serenidade filosófica do Sacerdote do templo de Delfos, da sua vivência de marido e pai de filhos.

$\mathrm{Na}$ base da afectividade familiar, pedra angular do seu edifício pedagógico se desenvolve toda a sua filosofia da educação, delineada nos praecepta do seu De liberis educandis e ao longo de toda a obra moral, em que à influência estóica, à diatribe cínica e aos lugares comuns da filosofia popular, se sobrepóe sempre a sua forma peculiar de encarar a vida, decorrente da sua experiência e das suas mais profundas convicçôes.

encontra também a recomendaçáo do aleitamento materno, que favorece a relação afectiva entre mãe e filho (p. 522): uinculo amorem beneuolentiamque fauerent. Este motivo surge na tratadística pedagógica desde o Quattrocento (e.g. De re uxoria de Ermolao Barbaro) e figura no De regis institutione et disciplina (1572) de D. Jerónimo Osório, dedicado a D. Sebastiáo. O famoso Bispo de Sives náo omite a censura - que remonta às Noctes Atticae de Aulo Gélio (12.1) - às rainhas que devem amamentar os filhos, pois a natureza as dotou de dois seios como aos outros animais. E acrescenta um pormenor realista: nem só as rainhas, mas quase todas as mulheres de boa família, preferem partilhar com outras mulheres o dulcíssimo nome de mãe. Responsáveis por isso são as deliciae atque perditi mores dos tempos actuais (Opera Omnia 1592: I. 374. 25-36). 
A nível dos princípios, dos fundamenta em que assenta a educação, Plutarco, ou pseudo-Plutarco, ${ }^{56}$ encarece neste opúsculo pedagógico, De liberis educandis, a importância da natureza, o aperfeiçoamento das tendências naturais pela criação de bons hábitos, que moldam o carácter, ${ }^{57}$ o papel da memória, ${ }^{58}$ a crença na virtude que pode ser ensinada, ${ }^{59} \mathrm{o}$ valor da emulação, o sentido da honra, a cultura da vergonha, com origens na poesia homérica; a importância do carácter do preceptor e a sua arte em estabelecer uma relação de respeito e afecto, em dosear os louvores e as censuras, em evitar a fadiga, em incentivar, nos discípulos, o amor

56 Os humanistas atribuíram a Plutarco este pequeno tratado e nunca puseram em causa a sua autoria, pelo que não tem grande significado para o estudo desta época a opinião da crítica moderna, que é praticamente unânime em considerá-lo pseudo-plutarquiano. Assim atribuiremos a Plutarco as ideias nele recolhidas. Sobre a questão da autenticidade do De liberis educandis, que foi pela primeira vez levantada no século XVII, vide Francesca Albini 1977: 69, n. 2.

${ }^{57}$ A importância da tríade educativa, natura (ingenium), ars, studium (exercitatio) remonta aos pré-socráticos e conhece grande divulgação entre os sofistas e sobretudo a partir deles, tornando-se um tópico discutido por todas as escólas filosóficas. Vide Platão, Men. 70 a sqq.; Phdr. 269 d; Prt. 323 d; Lg. 792 e; Aristóteles, Pol. 1332 a 38-40; 1337 a 1; EN. 1179 b 20-21; Rh. 1410 b 6-7; Xenofonte, Mem. 3. 9. 2; 2. 6. 39; 3. 3. 11; Isócrates, Paid. III; Lucrécio, De rer. nat. 3.319 sqq.

58 A arte da memória, prática pedagógica do Renascimento, teve como mais antiga fonte que se conhece o poeta grego do século VI a. C., Simónides de Céos - a quem se deve a definiçao de tão grande fortuna, "a pintura é poesia muda, a poesia imagem que fala”. Vide sobre o assunto F. A. Yates 1975; Michele Simondon 1982: 181-190 (maxime).

59 Plutarco desenvolve esta temática no opúsculo moral, conhecido pelo título latino, An virtus doceri possit. O problema do ensino da virtude é já posto no Ménon por Platão. 
aos estudos, em que é nítida a inspiração platónica. Esta porém está condicionada ao contexto histórico e social de Plutarco e ao ponto de vista por si adoptado, que se prende prioritariamente com os fundamentos da educação e da moral. ${ }^{60}$

Plutarco dirige-se prioritariamente aos pais e recomenda-lhes que se empenhem acima de tudo na criação, formação e educação de seus filhos. ${ }^{61} \mathrm{Os}$ dois progenitores devem ter, em parceria, um papel complementar. À mãe, desde os cuidados a ter com o nascimento dos filhos, cabe-lhe amamentá-los, num estreitamento da ligação entre ambos, prevenir-se contra uma educação amolecida e branda, enfraquecedora do carácter e desencadeadora da filautia, precaver-se do turpilóquio, preservar os filhos de más convivências. Plutarco recomenda ainda aos pais que, sem olhar a gastos, providenciem no sentido de dar a melhor educação a seus filhos, sem se esquecerem de que também já foram jovens, para suportarem, sem se indignarem, as faltas de seus filhos: tal como os médicos - o símile, de grande fortuna, é colhido em Lucrécio (4.11-16) devem misturar a doçura, a prâtês, com o amargor das correcções. ${ }^{62}$ Em suma, a educação integral, concebida

${ }^{60}$ Vide, a este propósito, Ana Esther Velázquez Fernández 1999: 501- 514 .

${ }^{61}$ Vide Francesca Albini 1977: 59-71. Para uma análise das ideias do De liberis educandis, vide Dominique Faure 1960: 18-22; cf ainda, sobre este tratado, na sua especificidade, e na sua relação com o pensamento platónico, o referido estudo de Ana Esther Velázquez Fernández 1999: 501- 514.

${ }^{62}$ Cf. De liberis educandis, 13 d. É este um dos aspectos mais expressivos da teorização de Plutarco, com marcas indeléveis na 
como um bem supremo, será a preocupação primeira dos pais que, acima de tudo, devem ser exemplo, paradigma para os filhos.

Estas observações sobre a puerilis institutio caracterizam a educaçáo moderna desde o Quattocento, desde as obras de Pier Paolo Vergerio e Francesco Patrizi Senense aos tratados pedagógicos de finais do século XVI. ${ }^{63}$

$\mathrm{Na}$ tratadística portuguesa, o Livro da Virtuosa benfeitoria do Infante D. Pedro é um documento, no Portugal quatrocentista, das ideias da pedagogia moderna, veiculadas pelo tratado de Pier Paolo Vergerio, que o nosso «Infante das sete partidas» conhecera em Itália. ${ }^{64}$

Alguns passos são por demais significativos do proto-humanismo da corte portuguesa do século XV, que indiciam a permeabilidade da mensagem clássica e do ideal pedagógico de Plutarco. A crença na natureza humana e na sua perfectibilidade, através do ensino e da educação, é um dos aspectos notórios da modernidade do seu pensamento; a própria metáfora da terra, que deve ser cultivada para dar bom fruto - que se encontra em

pedagogia humanista, por revelar uma nova atitude face à criança, um ser em formação e não um adulto em miniatura. A modernidade do pensamento de Plutarco, que está na base da futura psicologia diferencial, defendida pelos pedagogos humanistas desde o Quattrocento, foi aceite com excessivas reservas pelo italiano Cataldo Parísio Sículo, o introdutor do humanismo em Portugal e educador da nobreza portuguesa. vide Nair N. Castro Soares 2002a: 311-340, maxime 321-323.

${ }^{63}$ Vide Nair N. Castro Soares 1994: 97-188.

${ }^{64}$ Vide Nair N. Castro Soares 1993a: 289-314. 
Cícero e em Plutarco e informa o tratado pedagógico de Vergério - está presente no Livro da Virtuosa benfeitoria: «Portanto assi como boos lavradores, com trabalhos e adubios, vençamos a terra que he maninha». ${ }^{65}$

Se D. Pedro, neste tratado, não apresenta uma ratio studiorum, um plano de educação régia ou aristocrática, no entanto, é manifesto o seu intelectualismo socrático, a preocupação da ensinança, capaz de proporcionar a sabedoria, "que a muytos tyrou e tyra de mal fazer» como afirma na famosa "Carta de Bruges", documento indispensável para se ajuizar, em plenitude, do pensamento pedagógico do Infante. Dirá, na Virtuosa benfeitoria: «que os benefficios da benquerença non devem seer tirados aaquelles cuja saude speramos». ${ }^{66}$ "Os duros e cruevees façamos brandos e amolentemos». ${ }^{67}$ "E, ffalando com boa graça, dando conselhos e boas ensinanças aproveytaremos quaaesquer que podermos». ${ }^{68}$

O primeiro cuidado a ter com a educação deve-se aos pais, que dão aos filhos "seer natural e criaçom» e «ensinança». ${ }^{69} \mathrm{E}$ acrescenta: "aquelle he julgado por besta cruevel que en seus filhos he negligente». ${ }^{70}$

O enaltecimento do papel dos aios e dos mestres, surge na pena do Infante em termos que não escondem

${ }^{65}$ Vide Infante D. Pedro e Frei João Verba 1999 (ed.) cit. VB: liv. II, cap. XXI, p. 132. Esta metáfora surge, de forma recorrente, no tratado pedagógico de D. Jerónimo Osório, De regis institutione et disciplina.

${ }^{66}$ Cf. $V B$, liv. II, cap. XX: 125.

${ }^{67}$ Cf. $V B$, liv. II, cap. XXI: 132.

${ }^{68}$ Cf. $V B$, liv. II, cap. XXI: 130.

${ }^{69}$ Cf. $V B$, liv. II, cap. XV: 99-100.

${ }^{70}$ Cf. $V B$, liv. II, cap. XVIII: 115. 
a sua sensibilidade, diria mesmo a sua ternura por quem se dedica à missão de ensinar, de orientar e formar para a vida, com paciência, disponibilidade e total desinteresse. $^{71}$

A ideia de que os mestres, pela emulação, "com certos louvores» e "com bóos ensinos», «exalçam em vertudes as naturezas» ajusta-se com perfeição à ideia, essência de toda a pedagogia humanista, de que "a educação é uma segunda natureza», na expressão de Erasmo, seguidor de Plutarco. ${ }^{72}$

$\mathrm{O}$ ideal de mestre, que aflora em todos os tratados de pedagogia humanista, senão mesmo nos manuais de gramática, como no prefácio da famosa gramática do Pe. Manuel Álvares, editada inúmeras vezes, no séc. XVI, e utilizada em todos os colégios da Europa, não está ausente das páginas da Virtuosa benfeitoria.

A este propósito, é de interesse lembrar que D. Pedro, pela valor e significado que confere ao papel dos aios e mestres, afirma que a eles nunca se dará total

${ }^{71}$ Cf.VB, liv. V, cap. VIII: 285: «E os meestres, ensinando specialmente, filham muyto trabalho e nojo e, afora aquello que he demostrado juntamente a todos, dam ensinanças outras em special, e per seus castigos exalçam em vertudes as naturezas, demovendo alguns com certos louvores e amoestando outros com bóos ensinos. $\mathrm{E}$ assy spertam o entendimento preguiçosamente adormentado que lhe tiram as treevas da ignorancia e lhe fazem conhecer o claro splendor»

${ }^{72}$ Erasmo, principal representante e divulgador do pensamento pedagógico moderno - que funda as suas raízes no Quattrocento italiano - irá afirmar, cerca de um século depois de D. Pedro, que a educação é uma segunda natureza, é fonte de toda a virtude: Fons enim omnis uirtutis est diligens ac sancta educatio (Opera omnia, Leiden, 1703: LB, I. $491 \mathrm{E)}$. 
agradecimento, "porquanto nunca podemos leixar de seer obrigados a quem per natureza somos tehudos». ${ }^{73}$

Embora marcado pela discursividade medieval, O livro da virtuosa benfeitoria do Infante D. Pedro pode considerar-se pioneiro na abertura aos valores humanísticos e aos ideais pedagógicos que as obras do século XVI, com nítida influência de Plutarco, privilegiam.

No que se refere à tratadística pedagógico-politica, a presença de Plutarco é notavel, designadamente a partir de Erasmo que, na Institutio principis christiani, difunde o gosto por este género de literatura no século XVI. Nesta obra erasmiana, não é por demais sublinhar, Plutarco figura à cabeça dos autores que o príncipe deve estudar, logo depois dos textos sagrados.

É, aliás, através da síntese que Erasmo faz das ideias políticas de Plutarco, que a sua doutrina ganha vida e actualidade, nos diversos tratados humanistas.

Plutarco é com frequência citado pelos tratadistas pedagógicos portugueses de Quinhentos, sobretudo a partir de Frei António de Beja, Breve doutrina e ensinança de principes (1525). ${ }^{74} \mathrm{O}$ nome de Plutarco surge explicitamente na Doutrina de Lourenço de Cáceres ao Infante D. Luiz. ${ }^{75}$

E, além de um ou outro pormenor biográfico, referente à educação dos príncipes, que ocorre

${ }^{73}$ Cf. $V B$, liv. V, cap. II: 267.

${ }^{74}$ Frei António de Beja 1965 (ed): 22 e 119.

${ }^{75}$ Vide António Alberto de Andrade 1965: 39 e 55 
esporadicamente nas obras históricas, ou de pedagogia política, a puerilis institutio, com marcada influência dos autores clássicos, designadamente Plutarco e Quintiliano, vai ser objecto da Institutio Sebastiani Primi de Diogo de Teive - dedicada a D. Sebastião, de sete anos de idade - e do De regis institutione et disciplina (1572), o tratado sobre a instrução e a educação do rei, de D. Jerónimo Osório, dirigido ao mesmo príncipe para o educar e corrigir. ${ }^{76}$ Este tratado pedagógico do Bispo de Silves, em oito livros, o mais completo de pedagogia e de pedagogia política do nosso humanismo renascentista, e dos mais expressivos da tratadística europeia, segue de muito perto, na doutrina e nos exempla, Plutarco, no De liberis educandis, no que se refere à primeira educação e formação de bons hábitos, e tem por referência constante toda a obra deste filósofo moralista, incluindo - já que se trata de um príncipe, ou antes de um rei - a de orientação política. ${ }^{77}$

Apesar disso, no De regis institutione et disciplina, nunca é referido o nome de Plutarco que, no seu tratado De gloria, é saudado como glória e honra de Roma, sem dela ser filho. ${ }^{78}$

76 Vide Hieronymi Osori Lusitani, De regis institutione et disciplina, Olysippone, excudebat Franciscus Correa, 1572. Mais vulgarizada é a edição dos seus Opera omnia, editada pelo sobrinho e homónimo, em Roma, em 1592: Hieronymi Osori Lusitani, Episcopi Algarbiensis, Opera omnia. In unum collecta, et in Quattuor volumina distributa. Romae, MDXCII.

77 Vide Nair N. Castro Soares 1994: 297 sqq.

${ }^{78}$ No final do livro III do De Gloria (ed. cit. I. 195. 39-44), D. Jerónimo Osório não se esquece de aludir expressamente a Plutarchus Cheronaeus, \& L. Seneca, aliique permulti, que não sendo 
Assim acontece com muitos autores do nosso Renascimento que apresentam, nas suas obras, marcas indeléveis da recepção de Plutarco. O próprio Camóes leu Plutarco, com certeza, e sem o citar, colheu nele muito do saber que informa Os Lusíadas. ${ }^{79}$

Frei Heitor Pinto aponta o nome de Plutarco, repetidas vezes, ao longo da sua Imagem da vida cristá, evocando as obras em que se inspira. Nem sempre, contudo, assim acontece. No "Diálogo da Tribulação", refere vagamente a obra de Plutarco, em que se apoia, veiculando o retrato ideal do príncipe, nestes termos: «Muitos subiram a honras, que a não tiveram tanta, quando as alcançaram, como infâmia, pelos meios com que as adquiriram. Donde veio a dizer Plutarco em uma epístola ao imperador Trajano, seu discípulo, que, com razão se podia dizer feliz seu império, pois fizera obras para o merecer, e não buscara maneiras para o alcançar». ${ }^{80}$

Para Plutarco, como para os autores da sua época, que imbuídos de eclectismo filosófico recebem a influência da diatribe cínica, a imagem do governante é impregnada de misticismo. E é nesta perspectiva, comum a D. Jerónimo Osório, que Frei Heitor Pinto, sem referir

filhos de Roma, doctrinae commendatione fuerunt in eam ciuitatem accepti, atque summis honoribus ornati.

${ }^{79}$ Afirma-o A. J. da Costa Pimpão 1989: XXV, no Prefácio à edição de Os Lusíadas. São estes os termos: «E que leu [Camōes] dos prosadores? Plutarco, com certeza. Em grego? Não necessariamente, pois traduçóes, como as de Amyot para língua francesa foram verdadeiro best-seller. A elas se refere Montaigne, designando-as por «notre bréviaire».

${ }^{80}$ Frei Heitor Pinto 1952 (ed.): 263. 
a fonte, afirma, no capítulo V do Diálogo da Justiça:

O bom príncipe e prelado é um sol comum a todos, que vigia sobre seu povo com muitos olhos, estando sempre no meio como o Sol que está no meio dos sete planetas. ${ }^{81}$

Como está distante esta imagem da que servirá de lema a Luís XIV, o Rei Sol, do século seguinte!

Frei Heitor Pinto, na sua Imagem da vida cristã, faz referência explícita a tratados morais de Plutarco, tais como o De tranquilitate animi ${ }^{82}$ e os que designa em português por 'Livro do ensino e criação dos meninos' 83 e por 'Livro dos proveitos que se nos seguem de termos inimigos que nos injuriem' ${ }^{84} \mathrm{e}$ colhe muitos dos seus exempla nos Moralia e nas Vidas Paralela, citadas com frequência. ${ }^{85}$ Não fora ele o teceláo, como se autodenomina, a ajuntar a «doctrina de diversos autores, \& de muytas autoridades», para fazer a sua teia. ${ }^{86} \mathrm{Ou}$ melhor, diremos nós, o doutrinador e moralista, a manifestar a sua abundante erudição, que visa sobretudo fins didácticos.

Plutarco figura destacadamente na obra de André Rodrigues de Évora, Sentenças de diversos autores pelas quaes amoestão aos príncipes como na paz e na guerra se devem reger, dirigidas ao muito esclarecido Principe Dom

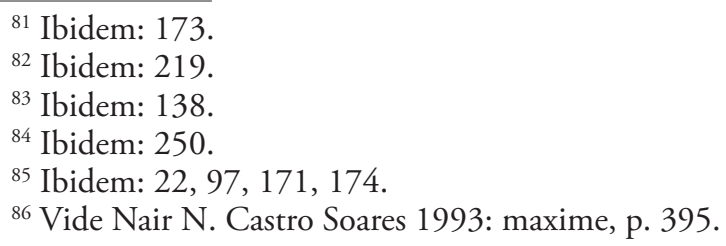


Sebastiāo, neto do mui Poderoso rei Dom João, Terceiro deste nome, nosso Senhor. ${ }^{87}$

Diogo de Teive não se esquece também de mencionar, nas suas Sententiae, "o excelente, gravissimo Plutarco" a quem deve muito da sua teorização. ${ }^{88}$

Entre nós, a literatura de sentenças, que Plutarco cultivou em obras como Regum et imperatorum apophthegmata e Apophthegmata Laconica, está bem representada desde os Prouerbia de Cataldo aos livros de Sentenças de D. Francisco de Portugal, primeiro conde de Vimioso, Diogo de Teive, Diogo Pires, André Rodrigues de Évora, Frei Luís de Granada. ${ }^{89}$

A presença de Plutarco nestas obras é notável, pela quantidade de textos representados e pelos juízos de valor que os acompanham.

Plutarco é indubitavelmente fonte inesgotável de argumentos que se repetem de autor para autor. ${ }^{90}$

Curioso é o aproveitamento que fazem de trechos ilustrativos da obra de Plutarco, as próprias oraçóes de sapiência, que se integram na pedagogia humanista

${ }^{87}$ Fac-simile do Manuscrito inédito da Casa Cadaval in Luís de Matos 1983 (ed.): 10-11; 82-83.

${ }^{88}$ Diogo de Teive 1786: 63.

${ }^{89}$ Vide Nair N. Castro Soares (1993), "A literatura de sentenças no Humanismo Português: res et uerba” cit.: 377-410.

90 Servem de exemplo, além fronteiras, as já referidas obras escritas para a educação de um príncipe menino ou de um rei no exercício do poder, tais como a Institution du prince de Guillaume Budé, o Livro de Marco Aurélio de Frei António de Guevara; entre nós, o Libro primero del principe christiano de Francisco de Monçon; a Institutio principis, precedia de uma colectânea de Sententiae de Diogo de Teive e o De regis institutione et disciplina, de D. Jerónimo Osório, dedicados ao mesmo rei D. Sebastião. 
e enunciam a sua ratio studiorum. Está neste caso a Omnium Philosophiae partium laudibus et studiis, 'sobre o estudo e louvor de todas as partes da Filosofia', de Hilário Moreira, 'proferida na Universidade de Coimbra, a mais próspera de todo o mundo, segundo o costume da Academia, em 1 de Outubro do ano do Senhor de 1552', como se lê no frontispício da edição de Coimbra dos tipógrafos régios João Barreira e João Álvares, saída a lume no mesmo ano em que fora apresentada. ${ }^{91}$ A iniciar esta oração, figura um longo passo, que contém o elogio das letras, do De liberis educandis, 10, em tradução latina, colhida na Miscelania Velasci de $1473 .^{92}$

Reveladores da importância e significado da mensagem de Plutarco, na construção do discurso quinhentista, são o Diálogo da viciosa vergonha de João de Barros. ${ }^{93}$ e o Colloquium de Luisa Sigeia, um diálogo sobre a vida contemplativa, em contraste com a vida áulica, a vida activa. Nesta obra, Plutarco está

${ }^{91}$ Hilarii Moreirae Conimbricensis ad inuictissimum Lusitaniae Regem D. Joannem tertium de omnium Philosophiae partium laudibus, et studiis oratio. Apud inclytum Conimbricense lyceum universi terrarum orbis florentissimum de more Academiae habita Calend. Octob. Anno Salutis M. D. LII. Conimbricae, Joannes Barrerius et Joannes Alvarus Reggi Typographi excudebant.

${ }_{92}$ Vide Albino A. Matos 1990: 48-49 e 93.

93 O Diálogo da viciosa vergonha, inspirado no tratado de Plutarco, Peri dôsopias segundo afirma Barros (cf. fol. A ij vo da edição princeps de 1540), in Maria Leonor Carvalhão Buescu 1971. Sobre a inspiração de Barros na tradução de Erasmo desta obra de Plutarco, e não no original grego, vide Américo da Costa Ramalho 1986: 275-280. 
representado, em profusão, com trechos de muitas das suas obras, na lingua original. ${ }^{4}$

Também António Luís, um humanista da primeira metade do século XVI, comentador de Galeno e Aristóteles e crítico de Erasmo, demonstra conhecer e apreciar o autor de Queroneia. Não só no tratado De pudore sobre a mesma matéria do Diálogo da Viciosa Vergonha - que dedica a João de Barros -, mas também nos Problemmata. ${ }^{95}$

Entre as fontes apontadas por António Luís para este tratado científico - que, no seu título, é designado de opus absolutum, et facundum, et uarium, multiingaque eruditione refertissimum, 'obra completa e eloquente, cheia de multifacetada erudição' - encontra-se Plutarco, que é citado em vários dos seus tratados. ${ }^{96}$

De grande voga no Renascimento são as obras que se ocupam das biografias de homens ilustres, a que dão o tom as Vidas Paralelas de Plutarco. A atitude epistemológica de Plutarco na seriação e apresentação

${ }^{94}$ Sobre o Colloquium de Luísa Sigeia, vide em Odette Sauvage 1970. Cf. as múltiplas citaçóes de Plutarco, e. g.: 34; 37; 114-120.

95 Antonii Lodouici medici olyssipponensis Problematum libri quinque opus absolutum, et facundum, et uarium, multiiugaque eruditione refertissimum, Olyssipone, M. D. XXXIX. Esta obra foi parcialmente estudada, em tese de mestrado orientada pelo Prof. Costa Ramalho, por Manuel Chaves de Andrade 1995.

${ }^{96}$ Vide Ad lectorem praefatio auctoris, onde confessa ter seguido, na preparação da sua obra, os autores gregos, sobretudo estes: Galeno, Próculo, Plutarco, Platão, Aristóteles, Alcino, Alexandre, o divino Dioniso e inúmeros outros» Entre as obras de Plutarco que cita, figuram os Apophthegmata, o tratado intitulado Maxime cum principibus uiris philosopho esse disserendum e os Coniugalia praecepta. 
dos factos, em ordem à dignidade que imprime às Vidas dos seus varôes, vai ao encontro do espírito humanista, com raízes em Petrarca e Lorenzo Valla, que subordinam a cultura à moral. Assim, no prefácio do De uiris illustribus, que inicia o género, Petrarca acentua o valor paradigmático da obra, como guia de conduta.

Significativa é também, neste sentido, a Vida do Infante D. Duarte. de André de Resende, dirigida ao Senhor Dom Duarte, duque de Guimarães, seu filho. O humanista eborense, apreciador de Plutarco - como o revela a sua oração de sapiência de 1551 , onde se lhe refere como escritor da maior autoridade, Plutarchus grauis cum primis auctor -, conclui nestes termos a sua biografia: "Esta é a lição, Excelente Senhor, que desejei de ler, da qual confio eu que V. Excellencia poderá tirar documento, de que muito se aproveita, se frequentemente a ler, e fizer a sua lembrança familiar». ${ }^{97}$

A própria História, no Renascimento, herdeira da concepção de Cícero em De oratore (2. 9. 36), ${ }^{98}$ muito deve à obra de Plutarco, que tratou paradigmaticamente a história dos seus varóes ilustres, gregos e romanos, impondo-os como modelos de comportamento ético, cívico e político, que a tradição literária veiculou. ${ }^{99}$ Exemplar, neste domínio, é a Historiografia Portuguesa, designadamente a obra de João de Barros. ${ }^{100}$

${ }^{97}$ Vide José Pereira Tavares 1963: 132.

${ }^{98}$ São estes os termos ciceronianos: Historia uero testis temporum, lux ueritatis, uita memoriae, magistra uitae, nuntia uetustatis.

${ }^{99}$ Vide John Dillon 1977: 233-240.

${ }^{100}$ Vide Nair N. Castro Soares 2002: 15-37. 
A poesia quinhentista indicia também a influência de Plutarco: André Falcão de Resende, na "Epístola I: a Heitor da Silveira, seu cunhado, estando na Índia", escreve: «A Sparta que alcancei de Deus com tudo,/minha consorte digo, amo e acompanho». Esta expresssão figurada, que se tornou proverbial, encontra-se nos Moralia e também nos Adagia de Erasmo, como provou o Prof. Costa Ramalho. ${ }^{101}$

Ainda a propósito de expressôes sentenciosas, um dos Ditos portugueses dignos de memória, editados pelo Prof. Hermano Saraiva, refere-se a uma resposta, um salse dictum, de D. Jorge, filho bastardo de D. João II, dada a um parente seu, que o interpelava sobre o casamento que ele queria contrair com uma rapariga nobre, muitos anos mais nova do que ele, sendo nisso contrariado pelos filhos, sobretudo pelo mais velho, D. João de Lencastre, duque de Aveiro. A resposta de D. Jorge, o discípulo de Cataldo, é a mesma de Catão o Antigo, confrontado com situação semelhante, que figura nas Vidas Paralelas de Plutarco. ${ }^{102}$

${ }^{101} \mathrm{Na}$ origem desta expressão figurada, contida nestes dois versos, está um passo da tragédia euripidiana Télefo, que, perdida a ligaçáo com o texto original, se tornou provérbio, a significar genericamente: "aceita o que te coube em sorte e estima-o», "da sorte que tiveste, não te queixes, mas tira dela o possível partido».

Este provérbio surge em dois trechos dos Moralia de Plutarco, bem acessíveis aos leitores do século XVI: no De Tranquillitate animi e no De exilio; figura em Adagiorum opus de Erasmo, que sobre ele disserta longamente. Segundo o Humanista de Roterdão, este provérbio tem diversas aplicaçóes: "por exemplo, quando aconselharmos alguém a que desempenhe com decoro o papel que assumiu». E explicita Erasmo: «É marido cumpra as obrigaçóes de marido». Vide Américo da Costa Ramalho 2000: 172-176.

${ }^{102} \mathrm{~A}$ resposta, cheia de ironia, de $\mathrm{D}$. Jorge é que queria casar 
Por tudo o que ficou dito um facto pode ser constatado: a influência de Plutarco no Humanismo, em Portugal, não é resultado do manuseio de colectâneas, em grande voga na época, de que são exemplo as de Ravisius Textor, Gregorius Reish, Niccolò Perotti. ${ }^{103}$

Pelo contrário, Plutarco, é lido e assimilado, no original, em tradução latina e em vulgar e, com a sua mensagem, informa a própria mundividência da época, no que se refere à educação e formação do homem e do príncipe, à teorização ético-política, ao relacionamento em família e em comunidade, às formas de comportamento humano, nas diversas circunstâncias.

A influência de Plutarco determina mesmo, muitas vezes, uma nova forma de mentalidade, uma nova atitude cultural, que passa pela reflexão sobre temas e motivos, em que se implicam e interpenetram parâmetros de carácter ontológico ou comportamental, do domínio da moral e da psicologia individual ou social, até então latentes, que se revigoram e actualizam através da mensagem de Plutarco.

Por último, um apontamento apenas sobre as ideias estéticas que se impuseram no Renascimento e se prendem com a recepção de Plutarco. Esta não se concretiza apenas como elemento informador da inuentio, da res inventiva, dos autores quinhentistas, mas

«Por ver se podia haver outros filhos tão virtuosos como os que já tenho». Vide A. Costa Ramalho 1998: 128-129.

${ }^{103}$ Vide Nair N. Castro Soares 1994: 226-228; Idem 1993 : 377-410. 
também, e de modo decisivo, na definição do estilo, da elegantia da latinitas.

A revitalização da retórica helenística e a reflexão sobre a obra de Plutarco, designadamente sobre a Vida de Cícero, vertida para latim por Leonardo Bruni Aretino, contribui para que se imponha a primazia do êthos, instância de enunciação centrada no eu, que privilegia, em nome da autenticidade, a presença do indivíduo na escrita

Nesta Vita Ciceronis, sobretudo na comparaçáo que estabelece, no seu final, entre Cícero e Demóstenes, favorável ao orador grego, resume Plutarco o seu ideal de estilo, em que o primado da energia moral e da acção se sobrepóe à retórica da palavra.

Neste sentido se orienta também o pensamento de Séneca, que, numa das suas cartas a Lucílio (14. 90. 20 ), previne o discípulo de que «o fascínio das palavras consegue desviar da verdade até mesmo os grandes espíritos». ${ }^{104}$

Esta retórica do êthos, que póe em relevo a força expressiva, a emphasis, do apotegma, do adágio, do provérbio, da sententia, em que se interpenetram concisão e propriedade, teve um papel preponderante na reflexão crítica da arte da palavra no Renascimento, designadamente na pedagogia de Erasmo, que exerceu marcada influência, entre nós, em pedagogos e mestres de retórica como Jerónimo Cardoso, Clenardo, João Vaseu, João Fernandes.

${ }^{104}$ Vide Lúcio Aneu Séneca 1991 (ed.): 445. 
A literatura de sentenças, de que Plutarco, com os seus Apophtegmata, é um lídimo representante e fonte privilegiada dos humanistas, assume, como observámos, uma importância singular, em Portugal e em toda a Europa do Renascimento.

Além de colectâneas de apotegmas, a produção dramática quinhentista reflecte o seu manuseio e memorização. Servem de exemplo os autos de Camóes e sobretudo as comédias de Jorge Ferreira de Vasconcelos.

Eugenio Asensio, no magistral estudo que abre a sua edição da Comédia Eufrosina considera-a "Un profuso repertorio de ejemplos y sentencias morales». E, a este propósito, acrescenta: «Los héroes y la sabeduría antigua penetraban en el mundo renacentista llevados por Plutarco y los textos de clase». ${ }^{105}$

Além da Eufrosina também a Aulegrafia entretece o seu discurso de apotegmas e provérbios, que, destacados no final da edição, ocupam várias páginas ${ }^{106}$ — a provar o gosto pela expressão sentenciosa, lapidar, que Plutarco privilegia.

Em suma, Plutarco exaltou o valor da virtude e apresentou a forma de a pôr em prática, serviu de modelo estético, no seu gosto pela breuiloquentia, e foi um dos autores mais lidos e imitados no século XVI.

${ }^{105}$ Vide Jorge Ferreira de Vasconcelos 1951(ed.): XI e XX, respectivamente.

${ }^{106}$ Note-se que a linguagem da comédia, que procura adequar-se ao êthos das personagens de baixa condição social, do vulgo ignaro, aos seus gostos e maneiras, reflecte, como nenhum outro género, as tendências e marcas expressivas próprias do tempo e exprime o gosto pela expressão sentenciosa. 
Defensor e representante de uma nova ordem social, Plutarco, com a sua mensagem - herança do pensamento grego dos séculos V e IV a. C., assimilada com eclectismo e apurada sensibilidade -, soube impor uma nova mentalidade, um novo estilo de vida.

Para se ajuizar do significado e relevância da sua obra, bastaria para tanto recordar as suas ideias sobre a educação do príncipe e do homem comum, precursoras da moderna psicologia diferencial; a importância da afectividade entre os esposos e entre pais e filhos; a obrigação moral dos pais investirem na educação daqueles que geram; o papel da mãe, a relação umbilical entre mãe e filho e a defesa do aleitamento materno; o casamento e as regras do bom viver matrimonial; o proveito que advém do convívio, em família, das pessoas idosas, que acumulam saber e experiência e se tornam pilares dos valores essenciais da vida. Enfim, a crença na perfectibilidade do homem, na cultura como instrumento de virtude e de uita beata.

Este ideal humano que é assimilado pelos autores mais representativos do Renascimento, tornou-se património da humanidade e conferiu a Plutarco, na distância de dezanove séculos, um lugar entre nós. 
Plutarco: o Regresso a terras itálicas

Rita Marnoto 


\section{Plutarco: O Regresso a terras itálicas}

Rita Marnoto

(Universidade de Coimbra)

A obra do Educador da Europa teve uma projecção vastíssima, na literatura italiana, ao longo de um percurso que se estende desde o século XIV aos nossos dias. Se a Península Itálica desempenhou uma funçãochave, pelo que diz respeito à recuperação moderna dos seus escritos, Plutarco é uma referência constante nas suas letras.

1. O papel da cultura italiana, enquanto fundamental via intermediária através da qual foi recuperado Plutarco, só poderá ser cabalmente compreendido tomando em linha de conta a continuidade dos elos que, ao longo da Idade Média, sempre foi mantendo com o mundo grego. É na esteira de um relacionamento que se alarga a campos muito diversos (de natureza comercial, administrativa, linguística ou religiosa) que o interesse pelo helenismo continua vivo, pontualmente, em alguns centros onde a língua grega é estudada e certos textos nela escritos são objecto de tradução. ${ }^{1}$

${ }^{1}$ Este quadro geral foi sintetizado por R. Weiss em alguns dos estudos reunidos em Medieval and Humanist Greek, com relevo para: "I. Greek in Western Europe at the End of the Middle Ages", "II. The Greek Culture of South Italy in the Later Middle Ages", "VIII. The Translators from the Greek of the Angevin Court of Naples", "XIII. Per la storia degli studi greci alla curia papale nel tardo Duecento e nel Trecento". 
No Sul de Itália, na Calábria, na Apúlia e na Sicília, os rituais da Igreja continuavam a seguir a prática grega. Era significativo o número de falantes de grego dessas zonas da Península, sendo, aliás, a linguagem quotidiana de comunicação herdeira próxima do grego clássico. ${ }^{2} \mathrm{Os}$ monges de S. Basílio de Cesareia de Capadócia tiveram um papel importantíssimo, ao longo de toda a Idade Média, na vida intelectual dessas regióes. Nas suas bibliotecas, encontravam-se guardados não só textos de índole religiosa, bem como de autores profanos (Aristófanes, Platão, Euclides, Homero, Galeno), também eles objecto de estudo. A actividade translativa de grego para latim encontra-se já documentada no século XII, recebendo grandes incentivos ao tempo do imperador Frederico II de Hohenstaufen e de seu filho Manfredi, que dominaram o Sul de Itália até 1266, data do recontro de Benevento. Nas suas chancelarias, notários latinos e sarracenos ombreavam com notários gregos. Quando a casa de Anjou assume o governo da Itália meridional, o interesse pela cultura grega de forma alguma decresce. Apesar de Carlos I não ter manifestado qualquer tipo de apreço pela produção dos poetas em vulgar que haviam circulado na órbita da Magna curia, formando a célebre "escola siciliana", o labor translativo continua a ser estimulado. Para além da teologia e da filosofia, são privilegiadas áreas ligadas

${ }^{2}$ Tal como o continuam a ser, na actualidade, os dialectos dessas zonas de Itália, pese embora uma evolução diacrónica que implicou, além do mais, a sobreposição de novos estratos linguísticos. Para uma perspectiva global desta questáo, vide: M. A. Cortelazzo 1984; Tulio De Mauro 1999; G. Devoto, G. Giacomelli 2002; Rohlfs 1969. 
ao saber prático, com relevo para a medicina e para as ciências naturais, ao mesmo tempo que é incrementada a busca de textos gregos. Foi também nesse período que, em nome das boas relaçóes entre a casa de Anjou e o papado, um bom número de códices gregos passou para as estantes da biblioteca da Cúria romana, onde veio a despertar a curiosidade de muitos humanistas. ${ }^{3}$ Outro foi o trágico destino do rico acervo napolitano, que ficou irremediavelmente sepultado nas águas do Adriático quando, na sequência da invasão de Luís da Hungria, em 1347-48, a embarcação que carregava tão portentoso saque sofreu um terrível naufrágio.

$\mathrm{Na}$ Cúria papal, a língua e a cultura gregas suscitavam um interesse muito particular, o qual, além de responder a exigências de ordem litúrgica, se encontrava intimamente ligado à necessidade de manter permanentes relaçóes com o mundo bizantino, em especial com a Igreja Grega, designadamente ao longo daquele período em que questão da união das duas Igrejas era um assunto de primordial importância. Tornava-se indispensável, pois, a constante disponibilidade de um corpo de intérpretes, embaixadores e missionários que dominasse a língua. No entanto, o grego que se estudava na Cúria, nos séculos XIII e XIV, não seria o grego

${ }^{3}$ Sinal da proximidade entre a casa de Anjou e o Vaticano, ao tempo do papa Clemente IV. Todavia, essa proximidade veio a revelar-se, da mesma feita, um obstáculo à união das duas Igrejas, quando Martinho IV excomunga Miguel VIII Paleólogo em 1281, na mira de deixar aberto um espaço susceptível de facilitar a conquista do Império bizantino por Carlos I de Anjou (cf. R. Weiss 1977: 194-195). 
clássico, mas, prevalentemente, o grego de Bizâncio e dos teólogos da Igreja Ortodoxa. Apesar disso, é num ambiente caracterizado por uma certa abertura ao mundo helénico que se enquadra a passagem pela Cúria de personalidades que deram um importante contributo ao incentivo do estudo do grego, como S. Tomás de Aquino e o seu colaborador Moerbeke, que traduziu numerosos textos a seu pedido. Aliás, não foram apenas os Dominicanos a apoiarem essa área do saber, pois também uma outra voz de grande influência nos meios romanos, Raimon Lull, corroborou a mesma posição. Não se possuem muitas informaçóes acerca do ensino do grego na Cúria, embora se saiba que era praticado, mas à margem de objectivos especificamente literários. Nesse quadro, emerge o nome de Barlaam Calabro. Monge de S. Basílio, Barlaam colaborara com os Anjou no sentido de organizar a secção helénica da sua biblioteca. Em 1339, encontra-se em Avinhão com uma missão diplomática e, em 1342, ensina grego na mesma cidade. A sua nomeação como Bispo de Gerace, a 2 de Outubro do mesmo ano, leva-o, porém, a abandonar a Cúria. O seu nome ficou célebre pelo facto de, entre os seus discípulos, se contar o "primeiro moderno", Francesco Petrarca ${ }^{4}$. Talvez trouxesse consigo o monge bizantino Símone Atumano, que encontramos de novo em Avinhão em 1363 (quando dá lições de grego a

${ }^{4}$ Sobre o conhecimento, pela parte de Petrarca, de Homero e da cultura grega, vide: ibid., cap. "X. Per la storia degli studi greci del Petrarca: il Triglossos", "XI. Notes on Petrarch and Homer", "XII. Petrarca e il mondo greco"; e Guido Martellotti, M. Feo 1983: 579-592 
Francesco Bruni) e, posteriormente, a partir de 1372, tendo-se transferido para Roma ao tempo de Urbano VI. Foi através da pena de Atumano que o Ocidente conheceu alguns dos primeiros textos de Plutarco. Mas já voltaremos à figura de Atumano.

Pelo que diz respeito às relaçóes comerciais com o mundo grego durante os últimos séculos da Idade Média, merecem destaque dois grandes centros do comércio mediterrânico, a República Veneziana e Florença. O vínculo que liga Veneza ao Império Romano do Oriente remonta ao século VI. Perante as dificuldades em fazer face à invasão lombarda, os venezianos solicitaram a protecção do Imperador, através do Exarco de Ravena, donde resultou uma situação de dependência da qual a Serenissima, nos séculos sucessivos, saberá tirar o melhor proveito em termos comerciais. Se bem que esse tipo de relacionamento não se traduzisse então, necessariamente, num efectivo interesse pela cultura e pela literatura gregas, facto é que, ao longo de todo o século $\mathrm{XV}$, Veneza será um dos mercados da Europa ocidental onde a aquisição de códices gregos é mais fácil. Por sua vez, a Universidade de Pádua era tradicionalmente frequentada por uma colónia de estudantes gregos, muitos dos quais cipriotas. Ao saber da presença, por aquelas paragens, de Leonzio Pilato, um calabrês aluno de Barlaam que, para elevar o seu coturno, se dizia oriundo de Salónica, ${ }^{5}$ Petrarca chama-o à sua residência paduana $^{6} e$, graças ao entusiasmo e às influências

${ }^{5}$ Cf. G. Billanovich 1947: 245-250.

${ }^{6}$ Petrarca possuía já o precioso códice de Homero que entrou 
movidas por Boccaccio, leva-o a aceitar a cátedra que lhe era oferecida pela Universidade de Florença. O autor da Genealogia deorum gentilium mantinha desde a sua juventude, passada na florescente corte napolitana dos Anjou, uma viva curiosidade pela língua grega, que nunca tivera verdadeira oportunidade de satisfazer. No Outono de 1360, o Calabrês dava início às suas liçôes de grego com base no texto de Homero, destinadas a uma ilustre plateia onde se integravam Giovanni Boccaccio, Domenico Silvestri e o franciscano Tedaldo della Casa. Mas a instabilidade e o espírito aventureiro que lhe eram próprios impediram-no de dar continuidade à leccionação. Em 1362, abandona Florença.

Desta feita, entre os pequenos núcleos da Península itálica onde o estudo do grego se fora mantendo vivo ao longo da Idade Média, vão começando a ser estabelecidos tímidos contactos, relativos à circulação de manuscritos e ao ensino da língua, que se processam, obviamente, no âmbito do inerente contexto epocal. Todavia, assim se vai delineando uma rede de linhas que se estende entre o Nordeste da Península e Florença, com estritas ligaçóes à Cúria papal, para se prolongar pelo Sul. É sintomático, pois, que na sua configuração fique esboçado o sistema

na sua biblioteca entre finais de 1353 e inícios do ano seguinte. Segundo U. Dotti 2004:192, tê-lo-ia adquirido através do bizantino Nicolau Sigero, personagem de grande cultura que conheceu em Verona nos primeiros meses de 1348, quando esse alto dignitário se dirigia para Avinháo, e com o qual logo estabeleceu uma amizade intelectual. Sobre a metodologia de Pilato, vide G. Martellotti 1983: 241-248, "Osservazioni sul carattere orale del primo insegnamento del greco nell'Italia umanistica”. 
de eixos de intersecção que marcará a geografia da literatura italiana do período renascentista - que é também dizer, a descoberta de Plutarco.

2. Posto isto, vejamos qual o lugar que cabe à obra do "Educador da Europa" neste quadro de relaçóes. No âmbito da actividade de translação incentivada pelos normandos, o seu nome é citado pelo tradutor do Fédon, Enrico Aristipo, ${ }^{7}$ no respectivo prefácio, em 1156. Não obstante, segundo Weiss, para o homem medieval Plutarco foi pouco mais do que um puro nome. ${ }^{8} \mathrm{O}$ proveito que Petrarca e Boccaccio tiraram das liçóes de Barlaam e de Pilato foi escasso, embora o esforço de aproximação à cultura helénica levado a cabo por estes intelectuais seja muito significativo. $\mathrm{Na}$ verdade, ficaram rasgadas vias que haviam de conduzir à implantação de grandes centros de estudo do grego e que constituíram, da mesma feita, pólos de referência basilares do Humanismo europeu. Recorde-se que "o

${ }^{7}$ Nos últimos anos, o mérito da actividade translativa levada a cabo por Aristipo tem vindo a ser posto em evidência, enquanto ponte mediadora através da qual a Idade Média latina teve acesso a muitos textos gregos e árabes. Traduziu o Ménon e o Fédon de Platão (a sua versão do Fédon serviu de referência às várias geraçóes de humanistas que vão de Petrarca a Salutati), o quarto livro dos Meteorologica de Aristóteles, e, muito possivelmente, Diógenes Laércio e Gregório de Nazianzo. Vide E. Franceschini 1962: 201-206.

${ }^{8}$ Cf. R. Weiss 1977: 205 e passim, onde também se colhem detalhadas informaçóes acerca das primeiras traduçóes e vulgarizamentos de Plutarco. Esclareça-se que, relativamente à época em causa, quando falamos em tradução nos referimos à versão de grego para latim, ao passo que a translação para a linguagem vulgar será designada como vulgarizamento. 
primeiro moderno" apenas conhecia Plutarco através de Aulo Gélio, e uma das notícias mais exactas que sobre ele possuía era a de que escrevera um tratado sobre a ira, De cohibenda ira, como resulta da epístola Familiaris 12.3.3. Para além disso, fica o legendário autor do apócrifo De institutione principum que Petrarca teria conhecido através do Policraticus de John of Salisbury. Apesar de esta situação nada ter de extraordinário, visto não implicar substanciais alteraçôes em relação ao horizonte de conhecimento do intelectual da Idade Média, não deixa de ser sintomático o facto de a primeira obra de Plutarco que o mundo ocidental viu traduzida ser esse mesmo tratado cuja existência fora assinalada pelo "primeiro moderno" - De ira.

Teria sido no ambiente da corte papal de Avinhão que os contornos da personalidade do "Educador da Europa" começaram a ganhar alguma nitidez. Foi tradutor do De ira aquele Símone Atumano que circulava pela Cúria na sombra de Barlaam. Teria sido também ele próprio a accionar os meios necessários para fazer chegar o original grego a Avinhão. Conforme consta da carta dedicatória datada de 20 de Janeiro de 1373, pôs mãos à empresa a instâncias do cardeal Pietro Corsini, uma interessante personagem da Cúria avinhonense dotada de vastíssimos e surpreendentes interesses culturais. É, da mesma forma, no círculo de literatos de Avinhão que surge uma outra versão de Plutarco, desta feita um conjunto de biografias que tem a particularidade de ser registado em aragonês. No centro de uma longa cadeia de relaçôes, encontra-se um catalão, Juan Fernández de 
Heredia, nomeado governador de Avinhão por Inocêncio VI em 1356, e depois eleito, em 1377, Grão-Mestre da Ordem do Hospital de S. João, então sediada em Rodes. A sua curiosidade pela obra de Plutarco levou-o a trazer dessa cidade uma versão do referido texto em grego moderno, lavrada pela pena de Demétrio Calódicos. Posteriormente, esse texto foi traduzido para aragonês em Avinhão, por Nicolau, Bispo de Drenopla (antiga Adrianopla, na Etólia), em data que tem por termo ante quem o ano de 1388. Ambas as versôes logo desfrutaram de uma larga difusão europeia.

Este episódio encerra o capítulo relativo à circulação medieval de Plutarco, ao mesmo tempo que rasga as vias conducentes à interpretação da sua obra sob uma nova luz. De facto, Weiss ${ }^{9}$ considera que o conhecimento de Plutarco não se distanciara ainda, nessa fase, da forma como a Idade Média lia os clássicos em sentido instrumental, ou seja, em função de objectivos utilitários. Além disso, essas duas versóes, pela falta de clareza e de limpidez expressiva que as caracteriza, bem como pelo frequente recurso a vocábulos gregos, não ultrapassavam as dificuldades de tradução próprias da época. A partir do momento em que são criadas novas condiçóes para o ensino do grego, em consonância com a metodologia humanista, Plutarco revela-se de imediato um dos autores cuja obra atrai sobremaneira a intelectualidade italiana. Mas só com a ascensão à ribalta do grande impulsionador do Humanismo florentino de

${ }^{9}$ R. Weiss 1977: 205. 
Quatrocentos, Coluccio Salutati, virá a triunfar aquela que Weiss, em 1955, designava como a new wave. ${ }^{10}$

3. Salutati herdara de Petrarca e de Boccaccio a admiração pelo mundo grego. Não é de estranhar, pois, que a notícia das traduçôes de Plutarco levadas a cabo em Avinhão logo despertasse a sua curiosidade. Satisfazendo os seus anseios, o cardeal Pietro Corsini faz-lhe chegar a versão latina do De cohibenda ira, provavelmente em 1392. Poderemos imaginar a expressão do rigoroso Chanceler florentino quando, ao lançar um ávido olhar para o manuscrito que tanto havia desejado, e que finalmente possuía, depara com um texto escrito num latim confuso e embrulhado, onde as palavras gregas eram tão frequentes, que ele próprio classificou a tradução como "semigrega". Mas a grande solução começa a cintilar-lhe na mente, e eis que póe mãos à versão de Atumano para dela elaborar uma magnífica paráfrase. $\mathrm{O}$ distanciamento do original grego, que, não raro, toca as raias da infidelidade, é compensado pela elegância do seu latim humanista. De toda a forma, trata-se de mais do que uma mera tradução. Com ela, Salutati póe em prática a sua proposta metodológica para a divulgação integrada da cultura grega através da língua latina. Perante a impossibilidade de conseguir traduçóes directas do grego susceptíveis de satisfazerem, em matéria de estilo, as suas exigências de humanista, impunha-se a sobreposição de uma paráfrase correctiva. Aliás, já Boccaccio se propusera

${ }^{10}$ R. Weiss 1977: 6. 
refazer o latim do Homero de Pilato. Salutati tem uma tal confiança nos resultados dessa metodologia, que logo insiste com Antonio Loschi para que a aplique à versão latina da Ilíada levada a cabo pelo mestre de grego do Studium florentino.

Mais problemáticos foram os contactos com Juan Fernández de Heredia destinados a obter o vulgarizamento aragonês. Salutati pretende alargar o seu método a outras áreas linguísticas, propondo-se elaborar, desta feita, uma tradução de aragonês para latim. ${ }^{11}$ Chega a pôr à disposição do Grão-Mestre da Ordem do Hospital a tradução da Odisseia feita por Leonzio Pilato, mas nem assim o consegue demover. É uma vicissitude da história política da época a proporcionarlhe a posse de táo ambicionado texto, do qual a breve prazo se irá, porém, desinteressar. Ao conhecer o anseio do Chanceler florentino, o antipapa Bento XIII, muito empenhado em estabelecer boas relaçóes com a cidade do Arno, logo descortina uma oportunidade de fazer valer a sua pessoa. Coluccio entra no jogo e a Odisseia de Leonzio Pilato parte de imediato para o Antipapa. Entretanto, o vulgarizamento aragonês de Plutarco tarda a chegar a Florença, pondo o Chanceler em cuidados. Finalmente, tem nas mãos o Plutarco aragonês. Estamos em 1395. Salutati rejubila. Mas a rápida evolução dos estudos helénicos levá-lo-á a abandonar, a breve prazo,

${ }^{11} \mathrm{O}$ episódio é documentado pela correspondência referida em R. Weiss 1977: 218-219. Segundo este crítico (1977: 220-22), o texto aragonês, logo que chegou a Florença, foi traduzido para italiano por um anónimo florentino (talvez entre 1395-97), numa versão que granjeou um considerável sucesso. 
o seu método de tradução em cadeia. Um novo capítulo do estudo do grego no Ocidente estava em vias de se iniciar. $^{12}$

Um dos humanistas do círculo de Salutati, Roberto dei Rossi, tivera oportunidade de conhecer em Veneza, no ano de 1390, dois sábios gregos, Demétrio Sídrones e Emanuel Crisolora, de quem recebera algumas liçóes. Quando, de regresso a Florença, dá novas a Salutati acerca desse encontro, o Chanceler logo começa a esboçar um ousado projecto cultural. Por um lado, envia Iacopo Angeli da Scarperia a Constantinopla, a fim de estabelecer contactos com Sídrones e Crisolora. ${ }^{13}$ Angeli parte em 1395 e consegue chegar a Constantinopla, destemidamente, quando a cidade se encontra ameaçada

${ }^{12}$ E. Garin (21970: 51 ss.) considera que a difusão do saber grego, na Itália do século XV, se processa de acordo com três linhas que dizem respeito ao ensino ministrado pelos sábios bizantinos e à sua actividade de produção literária; à formação de um acervo de textos gregos consistente; e à produção dos próprios intelectuais italianos. Assim fica desenhado um percurso que se estende entre o início do magistério de Crisolora, a reunião do Concílio de Ferrara e de Florença em 1438-43, e a chegada do novo fluxo de doutos gregos a Itália na segunda metade do século, depois da queda de Constantinopla. A recepção do legado helénico assumiu profundas reflexóes na discussão dos grandes temas promovida pelos humanistas italianos, caracterizada pela sua viva incidência histórica. Para uma perspectiva geral do Humanismo italiano, valha por todas a referência ao mencionado capítulo de E. Garin ${ }^{2}$ 1970: 5-353. Sobre o contexto florentino, vide, mais recentemente, M. Martelli 1988: 25-201.

${ }^{13}$ Ao longo da estadia de Angeli, Salutati vai sendo informado, por via epistolar, da evolução das conversaçóes com Crisolora, ao mesmo tempo que insiste com o seu emissário a fim de que se esforce por trazer para Florença todos os códices que encontre da obra de Platáo e de Plutarco (R. Weiss 1977: 260). 
pelos Turcos. Por outro lado, Coluccio consegue que o Studium florentino ponha à disposição de Crisolora, que em matéria económica não era pouco exigente, uma cátedra de grego. É assim que, em 1397, Angeli regressa a Florença trazendo consigo Emanuel Crisolora. Salutati vencera de novo.

Com Crisolora, forma-se toda uma geração de humanistas italianos de projecção europeia (Roberto dei Rossi, Angelo da Scarperia, Leonardo Bruni, Poggio Bracciolini, Palla Strozzi, Pier Paolo Vergerio) e inaugura-se uma leccionação que depois virá a ganhar uma certa continuidade, com mestres táo ilustres como Guarino Veronese, Demetrio Scarano, Giovanni Aurispa e Francesco Filelfo. A Florença de Crisolora erige-se em pólo de atracção de grandes intelectuais vindos de outras partes de Itália para aprenderem grego, mas que, da mesma feita, emprestam também o seu lustro à cidade do Arno, tais como Pietro Miani, Ognibene Scola ou o célebre Pier Paolo Vergerio. De outra forma, muitos dos seus alunos, sendo florentinos, irão depois enriquecer o ambiente filo-helénico de outros grandes centros culturais, com relevo não só para a Cúria papal, num período em que as relaçóes entre Roma e Florença, na sua variedade, eram muito intensas, como também para a área véneta, a Lombardia e o reino de Nápoles.

Os elos que ligam o ensino do grego à divulgaçáo da obra de Plutarco não são do foro unicamente linguístico. Crisolora utilizava os seus escritos como manual que servia de base à leccionação, no quadro de um modelo de ensino que veio a ser reproduzido 
pelos seus ilustres discípulos. ${ }^{14}$ Desta feita, a projecção de Plutarco no ambiente do Humanismo florentino só poderá ser cabalmente compreendida em função da excepcional conjugação de uma série de factores: a presença de um mestre de grego que de há muito era declarado admirador da sua obra, e através de cuja mediação chega à cidade do Arno um considerável acervo de originais plutarquianos; a vinculação do ensino do grego aos seus escritos; a receptividade ao magistério do "Educador da Europa", no seio de um contexto político e histórico-literário muito premente; acrescente-se a isto o carácter modelar do Humanismo florentino, que tem por sucedâneo de forma alguma marginal a função atribuída ao exemplo de Plutarco no âmbito de uma campanha de promoção de alcance não só italiano, como também europeu, conforme veremos.

Mas não é Florença a única metrópole onde prosperam os estudos helénicos. Pelo grande palco da Península itálica, vai desfilando uma galeria de doutos bizantinos que faz do mundo grego uma realidade cultural cada vez mais próxima. Jorge de Trebisonda, um grego que desembarcara em Itália na qualidade de mediador para a união das duas Igrejas, descreve um longo e agitado périplo, a partir de 1418, por várias cidades, em algumas das quais lecciona grego, entre Pádua, Veneza, Roma e Nápoles. Por sua vez, Teodoro Gaza, natural de Salónica, chega a Itália em 1440, passando, além do mais, por Pavia, Mântua, Ferrara, em cuja Universidade

${ }^{14}$ Cf. V. R. Giustiniani 1961: 3. 
assumiu a cátedra de grego por três anos, Roma e Nápoles. Mas a personalidade da cultura setentrional que, por esses anos, se destaca de forma conspícua, em virtude da sua notável preparação helénica, é Guarino Veronese. Entre 1403 e 1408, Guarino faz uma estadia em Constantinopla, onde estuda com Crisolora. Valemlhe os estímulos culturais e económicos recebidos do patrício veneziano Paolo Zane, em consonância com um modelo sociológico característico da República. ${ }^{15}$ Quando regressa, póe em prática uma metodologia pedagógica baseada no bilinguismo entre latim e grego que é dimensionada à luz de uma rigorosa perspectiva histórico-filológica. Descreve um longo percurso pelo Centro e pelo Norte de Itália, que o leva por Verona, Florença, Veneza, Ferrara, onde é preceptor de Leonello d'Este, e Pádua. Nos seus bancos, formam-se intelectuais da craveira de Battista Guarini, seu filho (em cuja escola se formará, por sua vez, Aldo Manuzio), Vittorino da Feltre (que desempenhará uma função pedagógica de relevo na Mântua dos Gonzaga), Francesco Barbaro, Leonardo Giustinian ou Andrea Giuliano. Trebisonda e Francesco Filelfo (ou, de outra forma, o marido da culta Teodora Crisolora, filha do célebre mestre de quem Filelfo fora discípulo em Constantinopla entre 1420 e 1422), a partir de um certo momento, circulam em torno da sua figura. Se tivermos em linha de conta, para além disso, que em 1468 é oferecido a S. Marcos de Veneza um fundo constituído por 482 volumes gregos

${ }^{15}$ Sobre o Humanismo veneziano, vide V. Branca ${ }^{2} 1994$ : 194199; e M. Zancan 1988: 619-741. 
e 264 latinos, a dimensão de um quadro que já por si é dotado de vastas dimensôes ainda mais se dilata. Aqui radica um dos fundamentais estímulos do helenismo veneziano. O donatário da Biblioteca Marciana foi o cardeal Bessarion, um grego de Trebisonda nascido em 1403, monge de S. Basílio e arcebispo de Niceia, depois feito Cardeal pelo papa Eugénio IV, o qual revelou grande habilidade diplomática nas conversaçóes para a união das duas Igrejas.

É neste contexto que melhor poderemos compreender, à margem de qualquer tentativa de fácil esquematismo, a direcção prevalentemente formativa e filológica que norteia o estudo de Plutarco em Veneza e na área cultural que lhe é adjacente. $\mathrm{Na}$ verdade, o Humanismo veneziano é apoiado e promovido por um grupo de patrícios dotado não só de um alto sentido de independência moral, como também de uma absoluta autonomia económica. Seu representante prototípico é a figura do intelectual muito ligado à vida prática e dotado de profundas preocupaçóes cívicas, que se reparte entre o estudo das humanae litterae e a administração da res publica. Donde decorre o privilégio conferido ao conteúdo pedagógico da obra de Plutarco, bem como a atenção filológica dedicada ao seu texto, que em breve irá ser dado a conhecer a toda a Europa pelos prelos venezianos.

4. A ampla actividade translativa de Plutarco teve início nos alvores do século XV e sofreu um incremento tal que, porvolta de 1460 , todas as 'Vidas' se encontravam traduzidas, cerca de um quarto delas em mais do que 
uma versão. ${ }^{16}$ De outra forma, o texto dos Moralia colocava espinhosos problemas textuais, pelo que a sua translação se processou a um ritmo mais esforçado. ${ }^{17}$ Daí decorre a precedência cronológica da princeps em original grego dos Moralia, relativamente à das Vitae, amplamente divulgadas através de numerosíssimas versôes.

Cabe a Antonio Cassarino o mérito de ter sido um dos mais perseverantes tradutores dos Moralia da primeira metade do século XV. Siciliano de nascimento, viveu em Constantinopla de 1434 a 1438, onde satisfez uma profunda curiosidade intelectual por Plutarco e por Platão. De regresso a Itália, estabeleceu-se em Génova, onde ensinou grego, tendo concentrado o seu labor não só na tradução dos Apophthegmata Laconica, como também na tradução de mais nove Opuscula. Essas versôes foram muito apreciadas pelo Panormita, que as compilou na sequência da morte de Cassarino, ocorrida em 1447. Mas já anteriormente fora divulgada uma versão dos Apophthegmata Laconica e dos Apophthegmata ad Traianum, elaborada por um outro tradutor de renome, Francesco Filelfo. Os Apophthegmata ad Traianum foram dedicados a Filippo Maria Visconti, exaltando a grandeza do Duque de Miláo ao libertar Alfonso e Giovanni de Aragão, que tinha feito prisioneiros na batalha de Gaeta, travada em Agosto de 1435. Também os tratados de

${ }^{16}$ V. Giustiniani 1961: 6. Neste artigo, encontra-se reunida muita informação sobre as traduçóes das Vitae no século XV.

${ }^{17}$ Podem-se colher muitos dados sobre a difusão dos Moralia nas páginas do trabalho de R. Aulotte 1965, em particular, pelo que diz respeito à Itália, nas pp. 21-26 e 325-343. 
educação moral e cívica despertavam um interesse onde se reflectiam directamente as preocupaçóes pedagógicas características da época. Guarino Veronese, além de ter vertido para latim um considerável número de biografias plutarquianas (de Lisandro e Sila, que dedica ao seu pupilo Leonello d'Este, Sertório e Euménides, Alexandre e César, Díon e Bruto, entre muitas outras), traduziu o De liberis educandis em 1410, tratado que havia de exercer uma decisiva influência sobre a pedagogia humanista, e o De adulatore et amico, que dedicou a Leonello. Mal a arte tipográfica se instala em Itália, logo começam a ser batidos muitos desses Opuscula. Em 1471, o De liberis educandis e os Apophthegmata nas referidas versôes de Guarino e de Filelfo; em 1477, os Problemata, traduzidos por Giovanni Pietro dall'Avenza; em 1479, as Amatoriae narrationes por Poliziano; em 1485, o De civili institutione de Nicolau Sagundino, um grego que viveu em Veneza, o De brevibus clarorum virorum inter se contentionibus de Guarino e o De virtutibus mulierum de Alamanno Rinuccini; e, em 1497, o De virtutibus morum e os Praecepta connubialia de Carlo Valgulio e o De differentia inter odium et invidiam, vertido por mão anónima.

Pelo que diz respeito às 'Vidas', a actividade translativa deu os seus primeiros frutos com algumas décadas de avanço. Uma das primeiras versôes a vir a público teria sido a Vita Bruti, posta em latim pelo embaixador da intelectualidade florentina em Constantinopla, Angeli da Scarperia, em data que ronda o ano de 1400. Esse labor, nos anos subsequentes da sua vida, passados na Cúria romana, alargou-se à Vita 
Ciceronis, à Vita Marii e à Vita Pompei, bem como aos tratados De Alexandri fortuna aut virtute e De Romanorum fortuna aut virtute. Por sua vez, Leonardo Bruni dedica a Salutati a tradução da Vita Antonii antes de partir para Roma, em 1405. Uma tradução que de forma alguma é isolada, já que a ela se devem somar as Vitae de Catão de Útica, Sertório, Pirro, Demóstenes, Cícero e Aristóteles, bem como uma tentativa inconclusa de verter para latim a Vita de Demétrio.

A sua receptividade é emblematizada pela edição romana de 1470, preparada por Giovanni Antonio Campano e batida pelo impressor alemão Ulrich Han, que latinizou o seu nome como Udalricus Gallus. ${ }^{18}$ Tão significativo era o número de traduçóes que circulava em manuscrito, muitas delas de uma mesma Vita, como referimos, que o organizador desta empresa se propóe um objectivo antológico de índole selectiva. O sucesso da edição de Campano é documentado pelo número de reediçóes, cinco no século XV (em Estrasburgo, s. d.; Veneza, 1478, 1491, 1496; e Brescia, 1499),

18 Descrita por V. Giustiniani 1961, fonte das presentes referências. Giovanni Antonio era uma personagem de origem humilde, nascida nos arredores de Caserta em 1429, mas que conseguiu obter uma formação humanista graças ao seu próprio esforço. Frequentou fugazmente as liçóes de grego de Demétrio Calcondila (o mestre de Trissino) em Perugia. Viveu na órbita da Cúria romana, tendo ficado sobremaneira conhecido como autor da biografia de inspiração plutarquiana, Vita et res gestae Bracii Fortebracii. Preparou outros textos para o editor Udalricus Gallus, embora a crítica especializada convenha que nunca conferiu proeminente importância a essa actividade. Vide F. R. Hausmann 1974: 424-429. 
a somar às cerca de duas dezenas que virão à luz no século seguinte (em Veneza, 1502, 1516, 1538; Paris, 1514, 1520, 1521, 1532, 1533, 1557; Brescia, 1524; Basileia, 1531, 1535, 1542, 1547, 1549, 1550, 1553, 1554; e Lyon, 1548, 1552, 1560). ${ }^{19}$ Serviu também de referência a vários vulgarizamentos elaborados em Itália e no estrangeiro. Recorde-se a versão levada a cabo por Battista Alessandro Jaconello da Rieti na boa paz dos Abruzzi, que foi dada aos prelos em 1482, e à qual nos voltaremos a referir; a versão castelhana de Alfonso de Placencia, editada em Sevilha no ano de 1491 por Paulo de Colónia e associados; e a alemá, elaborada por Hieronymus Boner e impressa em Colmar por B. Grieninger em 1541, que teve várias reimpressóes.

De um relance pela edição das Vitae publicada por Campano em 1470, ressaltam à evidência dois factos, o envolvimento de largos sectores da intelectualidade italiana na actividade translativa ${ }^{20}$ e o excepcional relevo que assumem, no plano político, os destinatários em causa. Nas dedicatórias das traduçóes das Vitae, pode ler-se, à transparência, um importante capítulo da história italiana do século XV. É certo que a homenagem prestada por Guarino a Roberto dei Rossi

${ }^{19}$ Apesar disso, em Outubro de 1502 não era possível adquirir uma edição das Vitae no mercado livreiro florentino, dado que todas elas se encontravam esgotadas, tal era a sua procura; cf. infra, n. 36 .

${ }^{20}$ A saber: Alamanno Rinuccini, Antonio Beccaria, Antonio Paccini, Battista Guarino, Donato Acciaiuoli, Francesco Barbaro, Francesco Filelfo, Francesco Zeffi, Iacopo Angeli da Scarperia, Giovanni Aurispa, Giovanni Tortelli, Guarino Veronese, Lapo di Castiglionchio "il Giovane”, Leonardo Bruni, Leonardo Giustiniani e Pellegrino Agli. 
e a Francesco Barbaro com as 'Vidas' de Flamínio e de Díon, respectivamente, ou a dedicatória da biografia de Sertório a Antonio Loschi, por Leonardo Bruni, bem ilustram o alto valor que os humanistas conferiam à amizade. Mas esses nomes diluem-se numa panóplia de figuras muito influentes na política da época, tais como o papa Eugénio IV e vários Cardeais, Luís, rei de França, ou o duque Humphrey of Gloucester, quarto filho de Henrique IV, rei de Inglaterra. Das personalidades mais recorrentemente referidas, contam-se os membros da família Medici. A Cosimo dei Medici são dedicadas a Vita de Temístocles, por Lapo di Castiglionchio "il Giovane", ${ }^{21}$ e a Vita de Timoleonte, por Antonio

21 A biografia de Lapo Castiglione "il Giovane" (Averardo, 1406 ca. - Veneza, 1438) oferece-nos um exemplo paradigmático da função desempenhada pelas dedicatórias das Vitae plutarquianas enquanto instância mediadora na relação entre o intelectual e o poder. Pouco tempo depois da ascensão de Cosimo (1434), Lapo, cuja família não gozava das boas graças dos Medici, dedicalhe a tradução da Vita de Temístocles, na esperança de com ele estabelecer um melhor relacionamento. Perante os escassos resultados da empresa, tenta a sua sorte em meios ligados à Cúria papal, o que o leva a dedicar a Solonis vita ao cardeal Casanova em 1435. Na sequência da morte desse alto dignitário, no ano seguinte, consagra as Vitae de Teseu e Rómulo ao cardeal Prospero Orsini, que muito o desilude, num momento em que Lapo é ameaçado com um processo inquisitorial. Dirige-se entâo a Giovanni Vitelleschi, aquando da sua nomeação como Arcebispo de Florença, consagrando-lhe a Periclis vita. Perdidas as esperanças de suceder a Filelfo no Studium florentino, endereça a Alfonso de Aragão a Fabii Maximi vita. Finalmente, é-lhe oferecido um lugar de leitor na Universidade de Bolonha, ao qual é, porém, forçado a renunciar por razóes de saúde. Entretanto, em Ferrara, é encarregado da tradução dos textos gregos do Concílio, o que lhe vale a proximidade do cardeal Giordano Orsini, homenageado 
Pacini. Piero dei Medici recebe de Donato Acciaiuoli as biografias de Demétrio e de Alcibíades, bem como as Vitae pseudoplutarquianas de Aníbal e de Cipião Africano. Pellegrino Agli, um humanista muito próximo de Ficino, dedica duas biografias pseudoplutarquianas de Homero a Lorenzo dei Medici. O elenco poderia ser alargado com muitas mais referências. Recordemos, além disso, o exemplo de Alamanno Rinuccini que, apesar de não ser propriamente um apoiante da casa de Medici, ofereceu a Cosimo, em 1463, por ocasião da morte do seu filho segundogénito Giovanni, a versão latina da Consolatio ad Apollonium que depois havia de endereçar a Federico da Montefeltro.

$\mathrm{Na}$ verdade, a portentosa fortuna das Vitae de Plutarco na Florença dos Medici assume um claro significado político. ${ }^{22}$ As personagens biografadas representavam, para o público dessa época, retratos ideais

na Publicolae vita, e do cardeal Giuliano Cesarini, a quem dedica a Arati vita. Organizou também um códice antológico com traduçôes das Vitae plutarquianas que circulavam em Itália para o duque Humphrey of Glouscerter (que teria desempenhado um papel importante no âmbito da divulgação das biografias nas Ilhas Britânicas), a quem consagrou, em 1437, a Artaxersis vita. Morre pouco tempo depois, sem nunca ter alcançado a tăo ambicionada integração na Cúria. Bem se pode dizer, pois, que a sua vida foi espelhada pelas versóes das 'Vidas' plutarquianas que elaborou e pelas suas dedicatórias. Lapo traduziu ainda Luciano, Teofrasto, Isócrates, Demóstenes e Xenofonte. Vide R. Fubini 1979: 44-51.

${ }^{22}$ Cf. M. Martelli 1988: 91 ss. Aliás, nas grandes polémicas de índole político-partidária acalentadas ao longo de todo o século $\mathrm{XV}$, a eficácia dos modelos governativos encarnados pelos heróis de Plutarco, bem como as suas interpretaçôes históricas, são intensamente debatidas; vd. E. Garin ${ }^{2} 1970$ : 129-132; e R. Weiss 1977: 269-270. 
de uma integridade cívica absolutae de uma total dedicação ao governo dos povos. Consequentemente, as Vitae respondiam, à perfeição, aos objectivos propagandistas da casa dos Medici, num momento em que se tornava absolutamente necessário justificar a centralização de um poder transmitido por hereditariedade. Mas, para além disso, a dinastia florentina nutria sérias ambiçôes à hegemonia peninsular, pelo que a exaltação da magnanimidade imperial tinha em vista uma intenção especular directamente apontada para as suas figuras de primeiro plano. Assim se compreendeque a encomenda da tradução de biografias plutarquianas a doutos helenistas, pela parte de membros da hierarquia governante, fosse prática corrente. Cosimo era um amante da filosofia que dominava o latim e o grego com elegância, dando menor atenção, pelo contrário, aos poetas em vulgar. $\mathrm{O}$ helenismo respondia muito bem, pois, aos seus ideais de elevação intelectual, indissociáveis do grande sonho de aproximar as várias Itálias. O interesse por Platão e pelos neoplatónicos que o levou a chamar Marsilio Ficino à Villa Careggio ombreava com o incentivo à tradução de Plutarco, enquanto faceta culturalista de um projecto dotado de implicaçóes muito vastas.

Mas uma das características que ainda mais acentua a especificidade do caso florentino diz respeito à abrangência dos grupos sociais implicados, numa diversidade de propósitos que, por vezes, parece tocar as raias do antagonismo. Desde inícios do século XV que a biblioteca do convento de Santa Croce tinha aberto as suas portas a Plutarco, graças à doação feita em 1406 por 
Tedaldo della Casa (o monge franciscano que frequentara as liçóes de Leonzio Pilato) da valorosa colecção de manuscritos que fora compilando e transcrevendo, ao longo de anos e anos. Todavia, mais surpreendente parece ser a receptividade de Plutarco em ambientes onde fermentavam posiçóes críticas em relação aos Medici. É esse o caso da Academia reunida em casa de Alamanno Rinuccini, que se dedicava à sua tradução. ${ }^{23}$ Frequentaram as suas assembleias Andrea Alamanni, Antonio Rossi, Marco Parenti e Donato Acciaiuoli. A adesão à causa mediceia, por parte de muitos intelectuais e de muitas famílias que ocupavam destacados lugares na sociedade florentina, não pressupunha uma conivência de facto. Essa aproximação visava, outrossim, o domínio de posiçóes, no seio da hierarquia instituída, susceptíveis de condicionar a forma como era exercido o poder. Os retratos de Plutarco representavam, para esses sectores, onde também se virá a integrar Maquiavel, um exemplo da grandiosidade e da liberalidade que esperavam caracterizasse o governo da sua cidade, não enquanto monarquia voltada sobre si mesma, mas res publica.

Nesse contexto, quando Lorenzo ascende ao poder, em 1469, dá continuidade ao programa político-cultural dos seus predecessores, mas com uma outra abertura em relação ao vulgar, a qual deixará marcas fortíssimas no Renascimento da cidade mediceia. ${ }^{24} \mathrm{O}$ "Magnifico"

${ }^{23}$ Cf. E. Garin ${ }^{2}$ 1970: 141.

${ }^{24}$ De entre os mais notáveis frutos desse projecto de valorização da língua e das letras florentinas, recordem-se a organizaçáo da Raccolta aragonese, bem como o incentivo ao comentário da obra dos grandes escritores toscanos e à vulgarizaçáo de um significativo 
compreendeu perfeitamente que a hegemonia florentina tinha de passar também pelo plano linguístico e os argumentos com que contava eram de peso - Dante, Petrarca e Boccaccio. É então que tem início um dos grandes capítulos da "età dei volgarizzamenti", para utilizar a feliz expressão de Dionisotti. ${ }^{25}$

A capacidade propulsora do programa linguísticoliterário do "Magnifico" é tal, que o seu exemplo não tardará a erigir-se em modelo que será seguido noutras zonas de Itália. É na sua esteira que deve ser situado o primeiro vulgarizamento de Plutarco que conheceu letra de forma, em $1482 .{ }^{26} \mathrm{O}$ autor da proeza não é uma personagem de grande plano. Battista Alessandro Jaconello da Rieti era um funcionário do Reino de Nápoles que, no último período da sua vida, optara por uma existência calma, no seu retiro de Rieti, em bom convívio com as letras. A sua versão baseia-se na edição romana das Vitae organizada por Campano em 1470. As dificuldades que tem de enfrentar, e das quais revela perfeita consciência, ilustram bem a determinação deste vulgarizador de Plutarco. No prefácio das Vite, Jaconelli

número de textos antigos, muitos dos quais de índole bucólica; vide R. Marnoto 1996: 30-33, 45-47.

${ }^{25}$ Vide o fundamental volume de C. Dionisotti ${ }^{4}$ 1999: 159-161.

${ }^{26} \mathrm{O}$ volume das Vite foi um dos primeiros incunábulos impressos em Aquila pelo tipógrafo alemão Adam von Rothwill. Nele fica contida uma primeira parte das biografias da edição de Campano. Esse vulgarizamento, melhorado e acrescentado, teve sucessivas edições italianas até 1527. Em 1525, Niccolò Zoppino reeditou, em Veneza, o texto de Jaconello e, na mesma data, imprimiu um segundo volume com as restantes biografias vulgarizadas por Giulio Bondone da Padova, também ele posteriormente reeditado. 
não poupa louvores aos Medici e ao seu projecto cultural, sem iludir, porém, os escolhos com que se defronta um vulgarizador que, como ele, maneja uma língua que não fala e que nem táo pouco aprendeu na escola, ou seja, uma língua morta - a língua literária de Dante, Petrarca e Boccaccio. Mas o anseio de divulgar Plutarco a um mais amplo círculo de leitores valia bem tal esforço.

Desta feita, o processo do vulgarizamento de Plutarco situa-se no fulcro do grande bívio do Humanismo italiano. Os ilustres impulsionadores desse movimento, aqueles eruditos detentores de um saber extraordinário, que falavam o latim de Virgílio e o grego de Simónides, visavam também o alargamento dessa cultura a um vasto público. Tal propósito nem sempre era facilmente conciliável, porém, com a devoção que dedicavam às línguas clássicas. A resposta da potência florentina foi a elevação da língua das suas três coroas a veículo literário de comunicaçáo dotado de uma dignidade susceptível de ser colocada em paralelo com a das línguas clássicas. Mas entre o toscano usado por Dante, Petrarca e Boccaccio, por um lado, e a língua falada na Florença dos Medici, por outro, ficava um fosso inquietante, como bem o notara o tranquilo Jaconello.

A proximidade do mundo grego, no âmbito do contexto a que já fizemos referência, levou ainda alguns intelectuais a alimentar o sonho de uma sociedade literária de inspiração helenista. Um dos seus mais requintados frutos, entre finais do século XV e inícios do século XVI, foi a actividade da Academia congregada 
em torno de Aldo Manuzio. Com a impressão da gramática grega de Constantino Lascaris, em 1495, Aldo dá início a uma actividade editorial cuja projecção, ao nível europeu, tem por pressuposto a sólida preparação filológica típica da escola guariniana. Plutarco não podia deixar de figurar, pois, nos seus catálogos. A princeps dos Moralia em original grego saiu dos seus prelos em 1509, com o título de Opuscula, sob o olhar vigilante de Demétrio Ducas, um grego de Creta, e do próprio Erasmo. ${ }^{27}$ Por sua vez, o original das Vitae é batido pelos herdeiros de Aldo Manuzio ${ }^{28}$ em 1519, dois anos depois de ter vindo a público a princeps florentina da bottega Giunta. Apesar da precedência cronológica da giuntina plutarquiana, a crítica especializada reconhece unanimemente o superior apuro da edição aldina. $\mathrm{Na}$ verdade, para além da erudição filológica que subjaz à sua preparação textual, há que ter em linha de conta o

${ }^{27}$ É a partir do seu texto que Erasmo elabora a tradução dos oito Opuscula Plutarchi nuper traducta, Erasmo Roterodamo interprete, editados por Froben em Basileia no ano de 1514 e reimpressos em 1518, a saber, Quo pacto quis dignoscere possit adulatorem ab amico, Quo pacto quis efficere possit ut capiat utilitatem ab inimico, De tuenda bona valetudine praecepta, In principe requiri doctrinam, Cum principibus maxime philosophum debere disputare, Utrum graviores sint animi morbi quam corporis, Num recte dictum sit $\lambda \alpha{ }^{\prime} \theta \varepsilon$

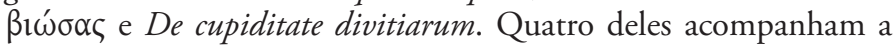
edição da Institutio principis christiani batida pelo mesmo impressor em 1516. Quando os herdeiros de Aldo Manuzio publicam a célebre edição dos opera de Erasmo de 1518, nela incluem não só a tradução erasmiana dos oito Opuscula, como também a de outros três.

${ }^{28}$ A actividade editorial de A. Manuzio situa-se no período cronológico que medeia entre 1494 e 1515, tendo sido posteriormente continuada pelos seus herdeiros. 
precioso acervo de códices plutarquianos a partir do qual foi elaborada - o fundo grego da Biblioteca Marciana de Veneza, cujo núcleo de base se formara graças à doação do generoso cardeal Bessarion. De outra forma, o esforço helenista dos Giunta diluia-se num ambiente que valorizava primordialmente a permeabilidade entre as línguas antigas e o vulgar.

Com Aldo Manuzio, extingue-se a aura de erudição helénica que perpassa pela Itália do Renascimento. A invasão estrangeira parecia iminente, como o prenunciara a conquista do Reino de Nápoles, em 1501, por tropas francesas e espanholas. Para responder a essa ameaça, a Itália tenta solidificar a sua identidade local através do reforço das suas raízes peninsulares, que são latinas.

5. Os caminhos ao longo dos quais toma forma a difusão dos primeiros códices de Plutarco, bem como a sucessiva tradução, vulgarizamento e edição desses textos, coincidem, indissoluvelmente, com os movimentos fulcrais do Humanismo e do Renascimento italianos, acompanhando também os percursos da sua projecção europeia. Tal dado de facto faz-se sinal da fortíssima incidência do seu magistério sobre o tecido cultural italiano, e não só no plano literário, como no plano histórico-político e dos costumes. Daqui decorre uma recepção produtiva caracterizada pela sua extensão aos mais diversos géneros da literatura vulgar e neolatina, cujas linhas gerais nos limitamos a esboçar. 
Para o florescente biografismo renascentista, as Vitae são uma referência que assume claras implicaçóes pragmáticas, em particular no ambiente mediceio, como vimos. Aliás, a valorização das grandes personalidades históricas da cultura florentina, numa galeria de retratos de inspiração plutarquiana, é parte integrante do seu projecto hegemónico. Mas o lastro dessa influência é muito mais vasto, quer em termos cronológicos, quer em termos geográficos. A evolução do protótipo biográfico medieval, centrado na exemplaridade religiosa, para o renascentista, que valoriza a conquista da virtude no plano histórico, tem por grandes modelos, além de Diógenes de Laércio e de Suetónio, Plutarco. Leonardo Bruni escreve, em vulgar, as biografias de Petrarca e de Boccaccio. Matteo Palmieri elabora a Vita Nicolai Acciaiuoli e Bartolomeo Scala compóe a Vita Vitaliani Borromaei. Por ocasiáo de uma viagem a Lucca, Machiavelli redige a Vita di Castruccio Castracani, cuja elaboração lhe sugere reflexóes a partir das quais tirará muitas das inferências acerca da relação entre o governante e o Estado consignadas em Il Principe. ${ }^{29}$ Por sua vez, Gianozzo Manetti (que também biografou o papa Nicolau V, Dante, Petrarca, Boccaccio e Niccolò Nicoli) segue o próprio método de Plutarco, quando coloca em paralelo as vidas de Sócrates e de Séneca. A partir de finais do século XV, começam a ser organizadas grandes sequências de relatos que têm por correspondente a veste

${ }^{29}$ Note-se, no entanto, que, com Machiavelli, o equilíbrio que Plutarco instaurava entre as capacidades de ânimo e a preparação bélica de alguns dos seus mais destacados heróis se desfaz a favor do segundo pólo. 
editorial das Vitae plutarquianas. $\mathrm{Na}$ compilação que Vespasiano da Bisticci intitula, sintomaticamente, Le vite, ficam reunidos 103 quadros. Paolo Giovio organiza várias colectâneas de biografias escritas em latim, parte das quais será vulgarizada por Giovan Battista Gelli. Por sua vez, Giorgio Vasari consagra as Vite de più eccellenti architetti, pittori e scultori italiani da Cimabue insino a' tempi nostri, numa edição de renome europeu.

$\mathrm{O}$ intuito celebrativo de muitos desses relatos anda intimamente associado à voga de Plutarco na historiografia. As referências directas a circunstâncias descritas nas Vitae, ao carácter exemplar das suas personagens, ou às consideraçóes contidas nos Moralia, são uma constante, de Leonardo Bruni a Poggio Bracciolini, Matteo Palmieri, Bartolomeo Scala e Machiavelli.

Outro domínio onde o "Educador da Europa" gozou de um incomensurável prestígio foi o da tratadística moral, pedagógica e dos costumes. Toda a paideia humanista se encontra imbuída pelos grandes ideais plutarquianos. Os seus fundamentos foram consagrados em obras de renome europeu, tais como o De studiis et litteris tractatulus ad Baptistam Malatestam de Leonardo Bruni, o De ingenuis moribus et liberalibus studiis adulescentiae de Pier Paolo Vergerio, ou o De liberorum educatione de Enea Silvio Piccolomini, dedicado a Ladislau "o Póstumo" da Boémia e Hungria. Nas páginas da primeira, Bruni mostra como é possível conciliar harmoniosamente os preceitos da pedagogia helénica com os princípios cristãos, ao passo que um 
dos aspectos mais inovadores de Vergerio consiste na recuperação do valor formativo da retórica clássica na educação do homem completo. Por sua vez, o breve tratado do futuro papa Pio II irá ter uma decisiva influência sobre a concepção do universo da infância. De outra forma, nos Libri della famiglia de Leon Battista Alberti, Plutarco é uma presença tão próxima dos interlocutores, que as normas de conduta e actuaçáo das personagens que biografou se erigem em guia prático para a boa resolução de muitas das questóes em causa. Também os diálogos de Poggio Bracciolini se encontram imbuídos de um moralismo directamente inspirado nos Opuscula. Para além disso, não deverá ser esquecida a prática de insignes mestres, como Guarino Veronese ou Vittorino da Feltre, que, apesar de nunca terem consignado por escrito o seu entendimento da paideia, a orientavam pelos ideais de Plutarco. Mas também nos ambientes palacianos o modelo de comportamento da mesma feita afável e rigoroso proposto pelo "Educador da Europa" alcança um valor exemplar, graças àquela celebérrima gramática do perfeito cortesão que Castiglione dedicou a D. Miguel da Silva, Bispo de Viseu - Il cortegiano. A tradução erasmiana dos Opuscula parece ter tido uma influência decisiva sobre a história do seu texto, em particular pelo que diz respeito à fisionomia da segunda redacção. ${ }^{30}$ Mas, para além disso, ao dissertar sobre a mulher, Castiglione segue um filáo da literatura quinhentista que se desenvolve, $a b$ origine, à sombra da

${ }^{30}$ Vide C. Scarpati 1987: 11-44. Pelo que diz respeito às traduçôes de Erasmo, vide supra, n. 27. 
lição plutarquiana, a tratadística de tema feminino. ${ }^{31}$ Através das páginas de Il cortegiano, Plutarco entra, pois, nas cortes das grandes capitais.

Mas o mais pitoresco sinal da familiaridade das letras italianas com a sua obra será a intersecção da herança literária do escritor helénico, em pleno Renascimento, com a tradição do Duecento e do Trecento, através de processos de contaminatio que desfrutam de particular incidência no campo da novela e dos apotegmas. Florença e a Toscana contam com uma insigne tradição da novela em vulgar, que afunda as suas raízes nas origens românicas, para se estender pelo Novellino, pelo Decameron de Boccaccio, o Novelliere de Sercambi, o Trecentonovelle de Sacchetti e muito para além deles. Nas suas páginas, os exemplos morais convivem com a sátira mordaz ou com a crónica do quotidiano, à luz daquela instância que Bachtin designou como carnavalesca. Quando, no século XV, o gosto pela tirada mordaz se cruza com o filáo novelístico, as histórias breves granjeiam um enorme sucesso. As suas fontes são, da mesma feita, de origem popular ou pseudopopular e erudita. Aqui entronca a recriação das sentenças plutarquianas, juntamente com os Facta et dicta

${ }^{31}$ A atenção dispensada ao modo como Plutarco concebe a mulher teve por fulcro a já referida tradução que foi elaborada por Poliziano em 1479 das Amatoriae narrationes. Essa famosa versão foi integrada na edição dos Opera omnia Angeli Politiani feita em Veneza, por Aldo Manuzio, em 1498, e, mais tarde, foi impressa separadamente em Roma, por Calvo, em 1525. Podem-se colher muitas informaçôes acerca da presença de Plutarco na tratadística quinhentista de tema feminino em M. L. Doglio 1993: 71-100 "Il Capra, i classici e le donne”. 
memorabilia de Valério Máximo, no seio da atmosfera carnavalesca típica da novela. Nas suas Confabulationes, também conhecidas por Facetiae, Bracciolini substitui às notáveis personagens de Plutarco um friso de figuras de extracção popular, ou até socialmente desintegradas, saídas das páginas do Novellino ou do Decameron. Foi também na sua esteira que Alberti compilou os Apologi e Poliziano organizou os Detti piacevoli. Neles se vieram a inspirar Ludovico Carbono e Leonardo, obedecendo, porém, a padróes mais canónicos. Recordem-se ainda, no âmbito da narrativa breve, as fábulas e as pequenas histórias de tema moral relacionadas com o mundo dos animais e com a metamorfose, ora escritas em verso, ora em prosa, quer em latim, quer em vulgar, onde a influência de Plutarco se associa à de Apuleio e de outros autores antigos. A brevidade da sua dimensão e a aparente ocasionalidade da composição de algumas delas não obstam a que sejam assinadas, não raro, por autores de renome - Alberti, Pontano, Firenzuola, Machiavelli.

Se com Guarino Plutarco entra nas escolas, com as Confabulationes de Poggio vagueia pelas ruas das contrade e com Castiglione entra na Corte, é porque o sábio de Queroneia consegue satisfazer as aspiraçóes modelares, da mais diversa ordem, de uma sociedade em férvida evolução.

Neste panorama, a fisionomia editorial dos Opuscula plutarquianos publicados a partir de inícios do século XVI distingue-se perfeitamente da tipologia quatrocentista. À edição de escritos isolados, traduzidos em latim, substitui-se o modelo da colectânea vertida para 
vulgar que é concebida em torno de núcleos temáticos fortes e complementada por índices remissivos. ${ }^{32}$ A reorganização e compilação por topoi responde a exigências de funcionalidade muito prementes na época, ao oferecer ao leitor uma quantidade ingente de informaçóes sistematizadas, que é dizer, prontamente disponíveis para reuso em consonância com as exigências da imitatio.

Plutarco, escritor transtemporal, erige-se definitivamente, na segunda metade do século XVI, num classico moderno, para utilizar aquela fórmula que tão bem caracteriza as escolhas do impressor veneziano Gabriel Giolito dei Ferrari. Giolito compreendeu perfeitamente que o erudito programa editorial de Aldo Manuzio tinha feito a sua época. O seu Plutarco é o Plutarco de massas da Itália quinhentista. Se Aldo possuía uma requintada erudição em matéria de helenismo, a sensibilidade de Giolito ao feed back do mercado livreiro não era menos fina. Em 1565, tem nos seus prelos um vulgarizamento dos apotegmas de Erasmo, essa fantástica compilação onde são reordenados exempla e máximas de grandes autores, cuja consulta e reutilizaçáo são facilitados por copiosos índices. $\mathrm{O}$ editor veneziano compreendeu perfeitamente, pois, que a versão erasmiana elaborada por Giovan Bernardo Gualandi se destinava ao grande público. Por isso mesmo, postos na balança os nomes do sublime Erasmo e do best seller Plutarco, Giolito decide-se pelo segundo. É assim que os Apoftemmi [....]. Motti

${ }^{32}$ Vide o elenco apresentado por R. Aulotte 1965: 340-341. 
arguti e piacevoli e sentenze notabili cosi di principi come di filosofi são impressos, em 1565, como obra de Plutarco. ${ }^{33}$

Por sua vez, o primeiro vulgarizamento das Vite que publica, elaborado por Lodovico Domenichi, sai em 1555 e tem numerosas reediçóes melhoradas nos anos sucessivos (1560, 1566 e assim por diante)..$^{34} \mathrm{Na}$ dedicatória a Guidobaldo II de Urbino, Domenichi lamenta a má qualidade do vulgarizamento que anteriormente circulava no mercado livreiro, numa alusão ao texto preparado por Jaconello e Bondone. ${ }^{35}$ $\mathrm{Na}$ verdade, o vulgarizador quinhentista não era atormentado por aquelas dificuldades linguísticas cuja resolução obrigara o funcionário de Rieti a recorrer a muitos termos dialectais.

A língua de Dante, Petrarca e Boccaccio tinha triunfado, apesar de o sonho hegemónico dos

33 Essa edição é descrita por S.Bongi 1890: 2, 208-209. Só muito recentemente foi apurado tratar-se de uma contrafacção, graças às pesquisas de Paolo Cerchi 1984: 208-225. A atitude de Giolito, ao atribuir a Plutarco um labor que não é da sua pena, tem por contraponto a do Stefano Guazzo que, no tratado La civil conversazione, recolhe numerosos exempla, máximas e sentenças no pseudo-Plutarco de Giolito sem revelar a sua fonte (cf. Quondam 1993: 1, XXXVIII-XXXIX).

${ }^{34}$ Estas edições foram descritas por S. Bongi 1890: 1, 478-479; 2 , 83, 218-219. A partir de 1566, Bongi encontra volumes com datas muito diversas, o que atesta o sucesso editorial do Plutarco de Domenichi. Esse vulgarizamento, que teve na sua base a edição romana de Campano, dominará o mercado até 1772-73, data da publicação, em Verona, da versão elaborada a partir do texto grego por Pompei. Entretanto, foram editados outros vulgarizamentos das Vitae de Campano, com destaque para o de Sansovino, mas que nunca mereceram o apreço do de Domenichi.

${ }^{35}$ Cf. supra, n. 26. 
Medici se ter desfeito. Esse vulgar que harmoniza a relação de um clássico helénico com a esfera de interesses do mundo contemporâneo é o supremo sinal do amadurecimento dos ideais do Humanismo renascentista e da sua incidência geograficamente unitária. Mas é também o seu derradeiro fruto, na medida em que se contenta com as liçóes dos humanistas do século XV. A partir de agora, a cultura italiana dá $o$ Educador à Europa.

6. O carácter pioneiro do papel assumido pelas letras italianas na recuperação da obra de Plutarco, pelo que diz respeito às suas implicaçôes filológicas, translativas e de recriaçáo literária, projectou-se na insigne recepção produtiva dos seus escritos ao longo dos séculos sucessivos, mediante uma linha de continuidade que se estende até aos nossos dias. Não sendo comportável, nos termos deste trabalho, a análise detalhada desse riquíssimo legado, limitar-nos-emos a apontar alguns pontos nodais de significado periodológico.

Quando o fulgor do Renascimento cede o passo à cosmovisão maneirista, Plutarco continua a ser uma referência iniludível em torno da qual tomam forma componentes semântico-formais periodologicamente estruturantes. A orientação crítica à luz da qual se efectua a sua leitura é já prenunciada pelas reservas que Machiavelli coloca ao De fortuna Romanorum, em nome da exaltação das capacidades bélicas e administrativas do povo romano levada a cabo pelo autor dos Discorsi sopra 
la prima Deca di Tito Livio. ${ }^{36}$ De outra forma, o sentido de desengano experimentado por Francesco Vettori, ao confrontar a Roma do seu tempo com a cidade imperial, fundamenta-se, além do mais, na memória de Plutarco. ${ }^{37}$

36 "Molti hanno avuta opinione, ed in tra'quali Plutarco, gravissimo scrittore, che 'l popolo romano nello acquistare lo imperio fosse più favorito dalla fortuna che dalla virtù. Ed intra le altre ragioni che ne adduce, dice che per confessione di quel popolo si dimostra, quello avere riconosciute dalla fortuna tutte le sue vittorie, avendo quello edificati più templi alla Fortuna che ad altro iddio. E pare che a questa opinione si accosti Livio; perché rade volte è che facci parlare ad alcuno Romano, dove ei racconti della virtù, che non vi aggiunga la fortuna. La qual cosa io non voglio confessare in alcuno modo, né credo ancora si possa sostenere. Perché, se non si è trovata mai republica che abbi fatti i profitti che Roma, è nato che non si è trovata mai republica che sia stata ordinata a potere acquistare come Roma. Perché la virtù degli eserciti gli fecero acquistare lo imperio; e l'ordine del procedere, ed il modo suo proprio, e trovato dal suo primo latore delle leggi gli fece mantenere lo acquistato: come di sotto largamente in più discorsi si narrerà." (N. Machiavelli 1971: 146); e cf. supra, n. 29. Desta feita, desenha-se uma linha de continuidade que desenvolve, sob uma nova perspectiva, as implicaçóes plutarquianas das polémicas quatrocentistas; cf. supra, n. 22. Esta orientação crítica não deve de modo algum ser confundida com um decréscimo pelo interesse da sua obra. Na carta que Biagio Buonaccorsi, a 21 de Outubro de 1502, envia de Florença a Machiavelli, para Imola, lamenta não poder satisfazer o seu pedido de remessa das Vitae, que então se encontram esgotadas no mercado livreiro dessa cidade (ibid., p. 1037).

37 "A nocte torno in casa; et ho ordinato d'havere historie assai, maxime de' Romani, chome dire Livio chon lo epitoma di Lucio Floro, Salustio, Plutarcho, Appiano Alexandrino, Cornelio Tacito, Svetonio, Lampridio et Spartiano, et quelli altri che scrivono delli imperatori, Herodiano, Ammiano Marcellino et Procopio: et con essi mi passo tempo; et considero che imperatori ha sopportati questa misera Roma che già fece tremare il mondo, et che non è suta maraviglia habbi anchora tollerati dua pontefici della qualità sono suti e passati.", escreve Vettori na carta que envia a Machiavelli 
$\mathrm{Na}$ tratadística consagrada às grandes questôes de poética e de retórica, o rastro dos seus ensinamentos é vastíssimo. $\mathrm{O}$ uso argumentativo dos pontos de vista defendidos por Plutarco, quer por parte dos neoplatónicos, quer por parte dos seguidores de Aristóteles, ilustra bem o prestígio de que gozava. Mas quando Piero Vettori, nos Commentarii in primum librum Aristotelis de arte poetarum, evoca a sua autoridade para reforçar a fundamental importância do plano expressivo no trabalho literário, em associação com a arte do concetto, rasga já as vias que conduzirão à sua fortuna no período do Barroco. Os seus escritos foram muito valorizados, em particular, nos círculos ligados à Companhia de Jesus, em domínios que vão do diálogo ${ }^{38}$ à biografia. ${ }^{39}$

Ao longo do período do Neoclassicismo, os modelos advogados pelo Educador da Europa voltarão a ter uma profunda incidência sobre a prática pedagógica e a preceituação que lhe é correlata, desta feita mediada pela

a 23 de Novembro de 1513, de Roma (ibid., p. 1158).

${ }^{38}$ Plutarco é um dos modelos explicitamente citados pelo autor do diálogo Observationes circa viventia, quae in rebus non viventibus reperiuntur, o jesuíta Filippo Buonanni. Esta obra, editada em 1691 na cidade papal, ostenta intençóes polémicas em relaçáo a Galileo e, muito particularmente, a Francesco Redi, conforme desde logo o sugere o próprio título, que decalca, latinizando-o, o do célebre tratado rediano Osservazioni intorno agli animali viventi che si trovano negli animali viventi.

39 Embora o biografismo barroco tenda a privilegiar, relativamente ao plano público, o dos conflitos interiores, através de uma aproximação senequiana que teve por grande representante, em Itália, o jesuíta Agostino Mascardi, o rigor e a exactidão de Plutarco preservam o seu carácter exemplar. 
experiência renascentista. ${ }^{40}$ Mas, para além disso, as suas páginas servem de guia a vastos estratos de homens de letras fascinados pelos ideais do mundo antigo. Náo obstante, a necessidade histórica de afirmação das próprias raízes romanas não dá tréguas ao autor do De fortuna Romanorum. Vico, nos Principi di scienza nuova, não hesita em acusá-lo de inveja. ${ }^{41}$

No quadro distanciamento das periodológico

europeu, últimas gerações de escritores

${ }^{40}$ A recriação de Plutarco em sentido moralizante estende-se aos mais diversos géneros literários, através de processos de contaminatio muito abrangentes. É notável o caso da "tragédia a lieto fine" do teatro jesuíta, que funde a grandeza dos heróis plutarquianos com a possibilidade de redenção cristã numa estrutura construtiva de inspiração clássica. Mas, para além disso, não deixem de se recordar, num âmbito mais lato, os grandes heróis da Antiguidade postos em cena pela dramaturgia cortesanesca setecentista, donde decorre uma linha de continuidade que se prolongará pelo século seguinte, espelhando os ideais do Risorgimento.

41 "Però qui è da ammirare la romana gravità e sapienza: che, in queste vicende di stati, i pretori e i giureconsulti si studiarono a tutto loro potere che di quanto meno e con tardi passi s'impropiassero le parole della legge delle XII Tavole. Onde forse per cotal cagione principalmente l'imperio romano cotanto s'ingrandì e durò: perché, nelle sue vicende di stato, proccurò a tutto potere di star fermo sopra i suoi princìi, che furono gli stessi che quelli di questo mondo di nazioni; come tutti i politici vi convengono che non vi sia miglior consiglio di durar e d'ingrandire gli Stati. Così la cagione, che produsse a' romani la più saggia giurisprudenza del mondo (di che sopra si è ragionato), è la stessa che fece loro il maggior imperio del mondo; ed è la cagione della grandezza romana, che Polibio, troppo generalmente, rifonde nella religione de' nobili, al contrario Macchiavello nella magnanimità della plebe, e Plutarco, invidioso della romana virtù e sapienza, rifonde nella loro fortuna nel libro De fortuna Romanorum, a cui per altre vie meno diritte Torquato Tasso scrisse la sua generosa Risposta." (G. Vico 1971: 666-667). 
neoclássicos relativamente a um historicismo que é sentido como cerceador da expressão pessoal não constitui uma novidade. Será sintomático, por consequência, que, no caso italiano, essa viragem se processe, mais do que através da influência de Rousseau, por via plutarquiana. ${ }^{42}$ $\mathrm{Na}$ verdade, ao longo de uma extensa parábola que se estende do Pré-romantismo aos movimentos de fim-deséculo, a permanência do legado clássico reflecte-se no equilíbrio gerado entre o entusiasmo pelas novas formas de percepçáo do mundo sensível e a serenidade da arte grega. Mas a enorme fortuna de Plutarco durante um lapso temporal de tão considerável extensão não pode ser dissociada dos anseios patrióticos que começam a fermentar mais intensamente na sociedade italiana pelos anos da Revolução Francesa e aos quais os valores éticos, heróicos e estéticos propugnados nos seus escritos correspondiam plenamente.

Nas Ultime lettere di Jacopo Ortis de Ugo Foscolo, um texto basilar da narrativa italiana moderna, Plutarco erige-se em perno em torno do qual volteia a conciliação entre a dimensão pública do contado e o plano privado, permitindo aberturas em relação ao comentário histórico-filosófico, às impressôes de viagem, à descrição da natureza e ao domínio metaliterário. ${ }^{43}$ Mas ao Jacopo

${ }^{42}$ Cf. M. Guglielminetti 1986: 874-879. Pelo que diz respeito a Alfieri, cf. infra, n. 46.

43 Essa mediação poderá ser ilustrada pelo passo: “Se m’è dato lo sperare mai pace, l'ho trovata, o Lorenzo. Il parroco, il medico, e tutti gli oscuri mortali di questo cantuccio della terra mi conoscono sin da fanciullo e mi amano. Quantunque io viva fuggiasco, mi vengono tutti d'intorno quasi volessero mansuefare 
Ortis, personagem de papel, que consola o seu desterro com o "divino Plutarco", ${ }^{44}$ anda associado o nome de várias personalidades históricas. ${ }^{45}$ Das masmorras venezianas dos Piombi, Casanova pede que lhe facultem a leitura das Vitae. Em vão, pois os rigorosos carcereiros só admitem obras ascéticas. Massimo Taparelli D’Azeglio tempera o seu retiro de Genzano com Plutarco. Alfieri póe fim, subitamente, ao seu périplo europeu, para se isolar em casa da irmã, onde, com o coração destroçado

una fiera generosa e selvatica. Per ora io lascio correre. Veramente non ho avuto tanto bene dagli uomini da fidarmene cosí alle prime: ma quel menare la vita del tiranno che freme e trema d'essere scannato a ogni minuto, mi pare un agonizzare in una morte lenta, obbrobriosa. Io seggo con essi a mezzodí sotto il platano della chiesa leggendo loro le vite di Licurgo e di Timoleone. Domenica mi s'erano affollati intorno tutti i contadini che, quantunque non comprendessero affatto, stavano ascoltandomi a bocca aperta." (U. Foscolo 1995: 13).

44 "Michele mi ha recato il Plutarco, e te ne ringrazio [...]. Col divino Plutarco potrò consolarmi de' delitti e delle sciagure dell'umanità, volgendo gli occhi ai pochi illustri che quasi primati dell'umano genere sovrastano a tanti secoli e a tante genti. Temo per altro che spogliandoli della magnificenza storica e della riverenza per l'antichità, non avrò assai da lodarmi nè degli antichi, nè de' moderni, nè di me stesso - umana razza!" (ibid.).

${ }^{45}$ A leitura das Vitae na prisão é atitude relativamente comum entre os intelectuais dessa época condenados ao cárcere, quiçá expressáo do intuito de desviar o pensamento, a todo o custo, das contingências do presente para o heroísmo biográfico dos magnânimos retratos de Plutarco. A difusora desta voga teria sido uma mulher, Jeanne-Marie (ou Manon Phlipon) Roland de la Platière (Paris, 1745-1793), uma intelectual apoiante dos girondinos casada com o Ministro do Interior Jean Marie Roland de la Platière. Madame de Roland foi presa a 1 de Junho de 1793 e executada em Novembro do mesmo ano. Na cadeia, escreveu as obras de fundo autobiográfico, Mémoires pour ma fille e Mes dernières pensées. 
pela bela holandesa, procura consolo nas biografias plutarquianas, que elege "libro dei libri", entre gritos e lágrimas. ${ }^{46}$ Aliás, se já Parini associava a eloquência à defesa activa dos grandes ideais cívicos na senda do exemplo do autor das Vitae, De Sanctis vê nos seus heróis o gérmen dos revoltosos napolitanos de $1799 .{ }^{47}$ Por sua vez, nas biografias de Francesco Lomonaco (Vite degli eccellenti italiani e Vite dé famosi capitani d'Italia) e de Francesco Domenico Guerrazzi (Vita di Pasquale Paoli),

46 "Le mie letture erano sempre di libri francesi. Volli leggere l'Eloisa di Rousseau; più volte mi ci provai; ma benchè io fossi di un carattere per natura appassionatissimo, e che mi trovassi allora fortemente innamorato, io trovava in quel libro tanta maniera, tanta ricercatezza, tanta affettazione di sentimento, e sì poco sentire, tanto calor comandato di capo, e sì gran freddezza di cuore, che mai non mi venne fatto di poterne terminare il primo volume. Alcune altre sue opere politiche, come il Contratto sociale, io non le intendeva, e perciò le lasciai. Di Voltaire mi allettavano singolarmente le prose, ma i di lui versi mi tediavano. Onde non lessi mai la sua Enriade, se non se a squarcetti; poco più la Pucelle, perché l'osceno non $\mathrm{mi}$ ha dilettato mai; ed alcune delle di lui tragedie. Montesquieu all'incontro lo lessi di capo in fondo ben due volte, con maraviglia, diletto, e forse anche con un qualche mio utile. L'Esprit di Helvetius mi fece anche una profonda, ma sgradevole impressione. Ma il libro dei libri per me, e che in quell'inverno mi fece veramente trascorrere dell'ore di rapimento e beate, fu Plutarco, le vite dei veri Grandi. Ed alcune di quelle, come Timoleone, Cesare, Bruto, Pelopida, Catone, ed altre, sino a quattro o cinque volte le rilessi con un tale trasporto di grida, di pianti e di furori pur anche, che chi fosse stato a sentirmi nella camera vicina mi avrebbe certamente tenuto per impazzato. All'udire certi gran tratti di quei sommi uomini, spessissimo io balzava in piedi agitatissimo, e fuori di me, e lagrime di dolore e di rabbia mi scaturivano dal vedermi nato in Piemonte ed in tempi e governi ove niuna alta cosa non si poteva né fare né dire, ed inutilmente appena forse ella si poteva sentire e pensare." (V. Alfieri 1965: 74-75).

${ }^{47}$ Cf. A. Battistini 1984: 165-167 e passim. 
as sugestôes plutarquianas incidem quer directamente, quer através da mediação do biografismo renascentista. A “italianização" oitocentista do autor dos Moralia e das Vitae bem poderia ser emblematizada pelo título de duas obras, as Operette morali de Giacomo Leopardi, dadas aos prelos em 1827 e depois, numa segunda versão aumentada, em 1834; e Il Plutarco italiano, com os seus quatro imponentes volumes editados em 1875 , onde fica contida uma panóplia de vidas de italianos ilustres.

No período que medeia entre finais do século XIX e inícios do século XX, a sua obra encontra receptividade no âmbito de um modelo cultural elevado, alheio a intuitos de divulgação. No catálogo Hoepli-Fumagalli de 1892, orientado por critérios de índole marcadamente selectiva, um dos entrevistados, Giuseppe Sergi, recomenda a sua leitura enquanto "utile e gradevole". ${ }^{48}$ Por sua vez, D’Annunzio, no prefácio de La vita di Cola di Rienzo, ${ }^{49}$ advoga energicamente a recuperação

48 "I libri che io vorrei fossero dati per lettura utile e gradevole sono principalmente quelli che si riferiscono alla formazione del carattere, o al consolidamento di esso, che sono suggerimenti dell'attività intellettuale e pratica sotto ogni forma, che inculcano l'indipendenza individuale con rispetto alla legge, che ispirano sentimenti disinteressati, con l'amore verso gli altri nella comunanza sociale e col rispetto dell'altrui personalità. Aggiungo a tali libri quelli che possono educare ai sentimenti estetici, i quali hanno grande influenza sui sentimenti sociali." (apud G. Ragone 1983: 741-742). A lista dos autores cuja leitura é recomendada por este Professor universitário é encabeçada por Plutarco.

49 "Osservato fu già come Plutarco, quando ci dice che Giulio Cesare era magro, di carnagione bianca e molle, soggetto al dolor di testa e al mal caduco, ci tocchi ben più a dentro che con gli 
do interesse biográfico por via plutarquiana, através da valorização da experiência vivida nos seus particulares. Em sua opinião, o significado dessas observações é mais rico do que o das elaboradas reflexôes comparativas das 'Vidas'.

Neste contexto, não será surpreendente o facto de os ecos da obra de Plutarco se estenderem às letras italianas dos nossos dias. Em 1993, foi dada aos prelos, por Giuseppe Pontiggia, uma série de biografias de figuras de ficção que viveram entre os séculos XIX, XX e XXI, sob o título de Vite di uomini non illustri. ${ }^{50}$ Não sendo apresentadas como personagens de excepção, conquanto dotadas de perfis vincados, essas figuras tendem a aproximar-se do horizonte do grande público, o que não será alheio à ampla receptividade do livro,

ingegni de' suoi paragoni. Quando Diogene Laerzio ci racconta che il divino Aristotile usava portar su la bocca dello stomaco un sacchetto di cuoio pien d'olio cotto e che, lui morto, fu ritrovata ne' ripostigli della sua casa gran moltitudine di coppi come in una bottegha di Samo, egli incita la nostra immaginativa ben più che con l'esporci non senza grossezza le dottrine del Peripato. Nelle biografie come nei ritratti noi dunque cerchiamo con avidità e gustiamo con gioia tra i segni della vita particolare quelli che più appaiono dissimiglianti dai comuni, quelli che non concernono se non la singola persona, quelli che di un capitano di un poeta di un mercatante fanno sotto il sole un uomo unico nel genere suo." (G. D’Annunzio 1960: 12). La vita di Cola di Rienzo foi a única biografia, integrada no vasto projecto intitulado Vite di uomini illustri e di uomini oscuri, que D’Annunzio levou a bom termo.

${ }^{50}$ Milano, Mondadori, com reed. G. Pontiggia é também autor de um volume dedicado aos clássicos, no qual ficam contidas várias referências a Plutarco (Pontiggia 1998). Agradeço ao Colega Carmine Ampolo todas as informaçóes fornecidas acerca da presença de Plutarco na actualidade italiana. 
atestada por sucessivas reimpressóes. Mas se, do plano da criação literária, passarmos ao da actividade crítica e editorial, deparamo-nos com um panorama que, nos últimos vinte anos, tem vindo a sofrer uma férvida e profícua evolução. O boletim da secção italiana da Plutarchean Society dá larga notícia dos múltiplos campos de pesquisa que têm vindo a ser persistentemente desbravados. De outra forma, mostra-se muito significativo o interesse despertado pela leitura da obra de Plutarco no seio dos mais diversificados estratos de público. São verdadeiramente notáveis os índices das tiragens das várias ediçōes de escritos breves, não raro excertos dos Moralia, promovidas pelas casas Adelphi e Sellerio, cuja versão é acompanhada, neste último caso, pelo texto original. Quanto às Vitae, encontram-se em circulação duas séries de edições críticas, publicadas pela Mondadori e pela Rizzoli, para além de numerosas ediçôes de divulgação.

7. De entre as poucas informações que se detêm acerca da biografia de Plutarco, ${ }^{51}$ conta-se a de que o autor das 'Vidas' passou alguns anos na Roma imperial, depois do que voltou à pátria Queroneia. Foi dessas mesmas terras itálicas que, na alvorada do Renascimento, a sua obra ganhou nova vida para a cultura da Europa. Um clássico lega-nos valores universais que século após século continuam a brilhar nas constelaçóes do entendimento. ${ }^{52}$ Mas esse legado transtemporal

51 "It is the irony of Fate that of Plutarch, the biographer, there is no biography", comenta F. C. Babbitt 1949: IX .

${ }^{52}$ Muito pertinentes, a este propósito, as palavras de A. Asor 
é inalienável do seu percurso através do tempo uma viagem feita de encontros e de desencontros, de inquietudes e de perplexidades, de partidas e retornos. Também nesta viagem de regresso às terras itálicas fica um pouco da vida de Plutarco.

Rosa 1998: 57: "Il tempo è [...] una componente ineliminabile della costruzione di un sistema dei classici, il fattore dinamico e conflituale, con cui si scontra l'aspirazione dell'auctor a durare, a non essere risucchiato nel grigio gorgo delle innumerevoli identità appena appena formulate, e poi perdute. Il classico vorrebbe fermare per sempre il tempo, ma non può, perché il tempo è in lui e lo muove. E siccome anche il classico è, come tutto nella storia, creatura umana, anch'esso, nonostante la durezza della sua corazza, si muove, e in questo consiste la sua vita". 


\title{
Plutarco e o Conceito de Virtude nos Revolucionários Franceses
}

\author{
José Ribeiro Ferreira
}




\section{Plutarco e o Conceito de Virtude nos Revolucionários Franceses}

José Ribeiro Ferreira (Universidade de Coimbra)

Alude-se sucintamente ao fascínio que a Grécia e Roma exerceram sobre a maioria dos revolucionários franceses e, em seguida, analisa-se a importância que atribuíam ao que chamavam a virtude republicana. Os traços essenciais dessa virtude encontraram-nos predominantemente na actuação dos grandes homens da Grécia e de Roma biografados por Plutarco, um autor que deve ter exercido papel importante na formação do espírito dos homens da Revolução. Estamos afinal perante uma educaçáo pelo paradigma que na Hélade tanta influência teve na formação dos jovens.

Ao ler os textos e intervençôes dos Revolucionários Franceses, deparamos amiudadas vezes com afirmaçóes que manifestam a intenção de serem os Licurgos da França, de imitarem, como seus modelos, os grandes generais e grandes homens da Grécia e de Roma: Fócion, Cévola, Horácio Cocles, Camilo, Cincinato, Catão, Bruto; os que consideram traidores são os Catilinas e os reis os tiranos; dão nomes de figuras da Antiguidade Clássica a ruas, a povoaçôes e comunas, ou às crianças recém-nascidas. ${ }^{1}$

É certo que, no confronto ideológico que então se verifica, nem todos têm idêntica visão da Antiguidade

${ }^{1}$ Ao assunto já me referi em J. R. Ferreira 1988: 203-234 
Clássica e consideram positiva e benéfica a imitação das suas instituiçôes e costumes. ${ }^{2}$ Mas boa parte deles pelo menos acreditava que o passado da Antiguidade Clássica tinha algo a ensinar à França. Adquirida essa crença, durante os anos de estudo, em contacto com as obras de autores antigos - na sua quase totalidade latinos - que se referiam a um passado grandioso e idealizado da Grécia e de Roma, a leitura de tais textos leva a geração revolucionária a admirar as virtudes e liberdades republicanas dessas duas sociedades e incita-a a seguir o exemplo dos seus heróis e governantes. ${ }^{3}$

$\mathrm{O}$ fermento estava lançado. $\mathrm{O}$ estudo dos autores antigos e o convívio com a história e instituições da Grécia e de Roma originaram, pelo menos indirectamente, uma mudança psicológica. Concebidas como perfeitas em comparação com a França em que viviam, a imitação do paradigma das comunidades clássicas significava no seu modo de ver uma transformaçáo radical.

Das referências à Antiguidade Clássica, as relativas a Roma são estatisticamente mais numerosas do que as

${ }^{2}$ Condorcet, por exemplo, era de opiniáo que a França não necessitava de imitar a Grécia e Roma. Apenas admite que com elas têm algo a aprender em política, antes da Revolução da América. Considerava que, em poesia e teatro, saber, cultura e direito, os Modernos eram superiores aos Antigos. Em consequência da Revolução e independência dos Estados Unidos da América, a partir de 1780, Condorcet menciona as instituiçóes dos Antigos apenas com desprezo e desdém: e. g. 1968: I 403-404, 446-447; II 41 ; III 373-374, 382-383, 402-403, 534-535, 551; VII, 97-99, 202-203, 268-269, 278-279, 374-375.

3 Sobre os estudos e textos lidos e comentados nos estabelecimentos de ensino frequentados por eles vide H.T. Parker 1937: 18-33. 
respeitantes à Grécia; dentro desta os Revolucionários mais influentes e radicais manifestam maior preferência por Esparta e têm no geral uma visão pouco positiva, para não dizer negativa, da democracia ateniense. ${ }^{4}$

Os Revolucionários, e em especial alguns dos mais influentes, acreditavam que conseguiriam uma transformação da sociedade francesa, se nela fizessem reviver as virtudes das repúblicas da Antiguidade Clássica. Por isso, procuram ressuscitar no seu país as instituiçóes e virtudes que vigoravam nos dias gloriosos da Grécia e de Roma. Para a consecução desse desiderato contam com o seu papel de legisladores e com o sistema educativo que pretendiam implantar.

Para muitos dos membros da Convenção, o ideal era a virtude severa das antigas Grécia e Roma, em especial de Esparta - uma virtude composta de austeridade e severidade com o próprio e com os outros, simplicidade e incorruptibilidade, caridade, doação e devoção à pátria. ${ }^{5}$ Saint-Just refere que "um governo republicano tem a virtude por princípio" e Robespierre vê na virtude política um princípio fundamental do governo democrático e popular e

${ }^{4}$ Dos numerosos exemplos dou apenas o seguinte, tirado de um discurso que Robespierre pronunciou na Convenção em 7 de maio de 1794. Para ele o espírito oportunista de Sólon deve ser evitado e considera que, na História, Esparta "brilha como um clarão nas trevas imensas". Cf M. Robespierre 1973: 158.

${ }^{5}$ Essa virtude é exaltada em livros, discursos, folhetos, cartas, panfletos, nos quais o recurso aos modelos da Grécia e de Roma é prática comum. Vide H. T. Parker 1937: 152-155; F. Díaz-Plaja 1960: 69-74. 
proclama num discurso de 29 de setembro de 1791, pronunciado na Assembleia Nacional:

Destruí a virtude e tereis tirado à corrupção o freio mais poderoso.

Os dois referidos revolucionários consideram assim essa virtude necessária às sociedades e acentuam que ela realizou prodígios na Grécia e em Roma. ${ }^{6}$ Os Jacobinos recomendavam a austeridade e a severidade como qualidades necessárias à salvação da República e, sobretudo durante o Terror, procuravam incutir uma vida ascética. Barère coloca o fundamento da república na virtude inflexível de Bruto e Courtois acentua que Nero temia mais um homem virtuoso, Traseas, do que todos os senadores juntos. ${ }^{7}$ Ainda no mesmo diapasáo Billaud-Varennes assegura:

A inflexível austeridade de Licurgo se converteu em Esparta no mais robusto pilar da República; o carácter débil e confiado de Sólon devolveu Atenas à escravidão. O cônsul Bruto, ao condenar à morte os seus dois filhos culpados de traição, compreendeu que tal severidade mesclada com terror abafaria por muito tempo os germes da conspiração. ${ }^{8}$

${ }^{6}$ Saint-Just 1968 : 327, 332-333e 358; M. Robespierre 1973: 39, 110-111,138 (citação da p. 39).

${ }^{7}$ Cf. Moniteur de 25 de abril de 1793, para Barère, e Moniteur de 18 de novembro de 1795, para Courtois (apud F. Díaz-Plaja 1960: 70 e 74, respectivamente).

${ }^{8}$ Moniteur de 21 de abril de 1794 (apud F. Díaz-Plaja 1960: 72). 
A virtude merece recompensa, mas o crime e a traição devem ser castigados. Por isso Villetard dá Roma como modelo, pelo modo como tratou Mânlio em duas situaçôes distintas: ergue-lhe uma casa no Capitólio, como monumento ao seu valor, quando expulsa os Gauleses desse local, mas pouco tempo depois, ao tornar-se culpado de traição, precipita-o do alto desse mesmo Capitólio. E Villetard conclui:

Eis aqui o caminho que vos traça o exemplo de uma nação digna de ser tomada como modelo ${ }^{9}$

Robespierre considerava mesmo a austeridade uma digna irmá da pobreza. No dicurso "Sobre a Popriedade", pronunciado na Convenção Nacional em 24 de abril de 1793, afirma ser uma quimera a igualdade de bens e que é mais urgente tornar honrosa a pobreza do que proscrever a opulência, já que a barraca de Fabrício - um consul romano que ficou como símbolo do magistrado incorruptível - não tem nada que invejar ao palácio de Crasso. Por isso proclama que preferia ser um dos filhos de Aristides, educado no Pritaneu a expensas da República, a ser o presumível herdeiro de Xerxes, nascido no lama da corte para ocupar um trono adornado com o envilecimento do povo e resplandecente com a miséria pública. ${ }^{10} \mathrm{Num}$ discurso de 5 de fevereiro

${ }^{9}$ Moniteur de 6 de Maio de 1795 (apud F. Díaz-Plaja 1960:74).

${ }^{10}$ M. Robespierre 1973: 99. Robespierre aduz mais vezes o nome do ateniense Aristides como exemplo do homem justo e incorruptível: por exemplo, na p. 141, estabelece o contraste entre a Atenas degenerada do tempo de Filipe da Macedónia e a da época 
de 1794, vai mais longe e defende que em determinadas alturas a virtude deve ser imposta pelo terror:

Se a força do governo popular é, em tempo de paz, a virtude, a força do governo popular em tempo de revolução é ao mesmo tempo a virtude e o terror: a virtude, sem a qual o terror é coisa funesta; o terror, sem o qual a virtude é impotente. ${ }^{11}$

Durante o Terror a Revolução incute um ideal de virtude que procura impor uma vida ascética. Depois do 9 Termidor, tal como em outros domínios, inicia-se a crítica a tal pretensão e apontam-se os defeitos dessa noção de virtude e os malefícios a que conduziu. $\mathrm{Na}$ sessão de 10 de novembro de 1794, uma voz anónima exclama no Congresso:

Reformem-se os costumes e os divórcios serão raros. Com os costumes simples da república, o romano ignorou o divórcio; com as normas corruptas da Roma imperial, o divórcio tornou-se tão frequente como o matrimónio. ${ }^{12}$

Mais significativa ainda é a afirmação de Cheviner, ao louvar os escritores e artistas que não se desonraram, pactuando com o Terror, mas trabalharam no silêncio do seu escritório

gloriosa de Milcíades e Aristides.

${ }^{11}$ M. Robespierre 1973: 143.

${ }^{12}$ Cf. Moniteur de 11 de Novembro de 1794 (apud F. DíazPlaja 1973: 73). 
.... acostumados, por assim dizer, a conversar com Aristides e com Catão de Útica, com Demóstenes e Cícero, não admiraram a homicida austeridade de um Couthon. ${ }^{13}$

Os traços essenciais desta concepção de virtude encontraram-nos por certo na actuação dos grandes homens da Grécia e de Roma biografados por Plutarco, um autor que, através da tradução de Dacier As Vidas dos Homens Ilustres - saída em Paris, em 1762 -, deve ter exercido papel importante na formação do espírito dos homens da Revolução. ${ }^{14}$ Aliás são frequentes as alusóes a esse autor grego tardio e à atracção que ele exercia. Ducos fala em Plutarco e cita as suas expressôes sobre o modo de encaminhar os cidadáos para a virtude. ${ }^{15} \mathrm{Mme}$ Rolland confessa que o contacto com Plutarco a tornou republicana, que em criança e na juventude chegava a levar para a igreja as Vidas Paralelas, em vez do livro de oraçóes, e que a sua leitura a transportava para o passado da Grécia e de Roma, a fazia identificar-se com os heróis aí biografados e compartilhar as suas paixões; lamentava mesmo náo ter nascido espartana ou romana. ${ }^{16}$ Brissot de Warville, um líder da Gironda, conta que, no último ano de estudante, o seu desejo de fama e os seus sonhos eram satisfeitos na leitura de livros, sobretudo de

${ }^{13}$ Cf. Moniteur de 5 de Janeiro de 1795 (apud F. Díaz-Plaja 1973: 73).

${ }^{14}$ No quadro apresentado por H. T. Parker 1937: 18-19 vemos que, depois de Cícero citado oitenta e três vezes, Plutarco é o mais contemplado com trinta e seis citaçóes, de par com Horácio.

${ }^{15}$ Cf. P. Kesse 1969: 111.

${ }^{16}$ Mme Rolland 1827 : I, 25/ II, 99. 
Plutarco, e ansiava assemelhar-se a Fócion, biografado por aquele polígrafo grego. ${ }^{17}$

Estamos perante uma educação pelo paradigma que, na Hélade, tanta influência teve na formação dos jovens e já a encontramos em acção nos Poemas Homéricos, quando Atena aponta a Telémaco o exemplo de Orestes para o motivar a ir colher informaçóes sobre o pai. ${ }^{18} \mathrm{O}$ Padre Gregoire encaminha-nos nessa direcção, ao referir que há tendência a imitar as grandes figuras do passado e ao aconselhar que se semeie virtude para recolher virtudes, já que, se a reputação de Milcíades inflamou o coração de Temístocles e o tornou seu émulo, um sofisma desorienta e um mau exemplo arrasta:

Semeemos a virtude, e nós colheremos virtudes. Foi esta a reputaçáo de Milcíades que inflamou o coração de Temístocles, e Temístocles tornou-se seu rival. ${ }^{19}$

Grande parte dos homens da Revolução encontravam esses paradigmas, de preferência, nos biografados de Plutarco e acima de todos eles estava Licurgo, o lendário legislador a quem a tradição atribuía a criação da Esparta clássica. Mas, se Licurgo é o modelo dessa virtude entre os Helenos, Marco Bruto e Catão

${ }^{17}$ B. de Warville 1911: I, 42.

${ }^{18}$ Depois os próprios heróis homéricos foram tomados como modelos pelos Gregos dos tempos futuros. Vide V. Ehrenberg 1964:10-12; J. Griffin 1977: 39-53;W. Jaeger 31954: cap. 3; H.-I. Marrou ${ }^{6}$ 1965: 1.

${ }^{19}$ Afirmaçóes de um discurso proferido na Convenção Nacional em 28 de setembro de 1793. Cf. A. Soboul (ed.) 1977 : 59-60 (citação da p. 59). 
de Útica são-no entre os Romanos, com prodominância para Bruto. Assim Cheviner acentua que a vida austera desse indefectível defensor da República romana oferecia o modelo da virtude. ${ }^{20}$

Lembrando ter sido graças à sua severidade que Licurgo impôs as reformas, Saint-Just é de opinião que pelo mesmo método se pode conseguir a regeneração rápida da França; para isso advoga a criação de instituiçóes que possam refrear o procedimento dos renitentes e incorrigíveis. ${ }^{21}$ Por exemplo, admite a necessidade de um ditador em toda a revolução, para salvar o Estado pela força, e propóe, para o salvar pela virtude, a criação de censores - que devem ser anciáos com mais de sessenta anos - com a finalidade de censurarem a vida privada e a vida dos funcionários. ${ }^{22} \mathrm{O}$ facto de Saint-Just ser membro da ditadura jacobina do Comité de Salvação Pública e de acreditar, à semelhança do que sucedeu na Grécia na época arcaica, no papel e no poder do legislador, induziu-o a sentir-se livre de ousar e de fazer a regeneração do seu país.

Da breve análise feita, pode concluir-se que a camada dirigente da Revolução Francesa estava profundamente identificada com a cultura da Grécia e de Roma, em cujas sociedades vêem realizaçóes ideais. Como consequência desejam moldar a vida do seu

${ }^{20}$ Cf. Moniteur de 5 de janeiro de 1795 (apud F. Diaz-Plaja 1973: 74).

${ }^{21}$ Saint-Just 1968: 327-329.

${ }^{22}$ Saint-Just 1968 : 358-360, 328, 340-341, 353-354. 
país por esses modelos e dotar a França com várias das instituiçóes que nelas encontravam. Acreditavam sobretudo que conseguiriam uma transformação da sociedade francesa, se nela fizessem reviver, quer através de um sistema educativo público, comunitário e igual para todos, quer por leis reformadoras, quais outros legisladores gregos, as virtudes das repúblicas da Antiguidade Clássica. Os modelos de tais virtudes encontravam-nos nos biografados por Plutarco. No que respeita à Grécia, podemos de modo geral afirmar que os elementos mais radicais sentem profunda admiração pela rígida, austera e disciplinada Lacedemónia, enquanto os mais moderados preferiam uma França à imagem da livre e democrática Atenas, onde todos os problemas podiam discutir-se sem reservas. Se dermos à afirmação uma certa amplitude nas excepçôes, podemos ainda generalizar mais e concluir, grosso modo, que os Girondinos se inclinavam para Atenas e os Jacobinos, que estiveram na base do Terror, eram adeptos de uma sociedade próxima da de Esparta. ${ }^{23}$ Aliás Taine descreve

${ }^{23}$ Alguns exemplos: Desmoulins é um apaixonado admirador de Atenas e ataca Brissot, um girondino, por admirar Esparta (vide A. Soboul 1980: 346); o girondino Ducos apoia o projecto de Lepeletier que, como vimos, apresenta muitas semelhanças com as práticas educativas de Esparta, enquanto o montanhês Duhem ataca esse mesmo projecto, na sessão de 22 de outubro de 1793, em que ele voltou a ser discutido, de acordo com o resumo do debate transmitido pelo Journal des débats et des décrets (M. J. Guillaume 1894: II, 673-677 reproduz esse debate); Grégoire e Lanjuinais, dois jacobinos, criticam Esparta e atacam a tentativa de a imitar (Para A. Soboul 1977: II, 30 (Guillaume 1894: II, 173) e Mme Rolland 1827: I, 344 ( M.J. Guillaume 1894: II, 178). 
o programa dos Jacobinos como uma tentativa de voltar às instituiçôes de Roma e de Esparta que eles tomaram como modelos. ${ }^{24}$

${ }^{24}$ Taine 1892: 115 e 121. 


\title{
Débito de Almeida Garrett a Plutarco
}

\author{
José Ribeiro Ferreira
}




\section{Débito de Almeida Garrett a Plutarco}

José Ribeiro Ferreira (Universidade de Coimbra)

Por várias vezes o próprio Garrett se declara devedor de Plutarco ou o erige como seu paradigma. Além de nomear e apresentar como modelos muitos dos biografados das Vidas do polígrafo de Queroneia, sem dizer explicitamente que essa é a sua fonte, confessa abertamente em outros passos que está a imitar Plutarco ou sugere que ele seja o modelo a seguir. Tal torna-se evidente em especial no opúsculo Da Educação. A comunicação procura analisar esse débito, confessado, ao autor de Queroneia, com mais demora no referido opúsculo.

Introdutor do Romantismo em Portugal, Almeida Garrett distinguiu-se como romancista, como poeta, como dramaturgo, como teorizador, como parlamentar. Com consistente formação clássica e bom conhecedor da história e da cultura da Grécia e de Roma antigas, mesmo depois de, na abertura da Dona Branca (1848) - cuja publicação coincide com a data de saída da primeira obra romântica - ter abjurado os «Áureos numes de Ascreu, ficçóes risonhas / Da culta Grécia amável», continuou a conviver com os clássicos. E Plutarco é um dos autores greco-romanos mais citados e mais recorrentes, talvez apenas superado por Homero, Virgílio, Horácio e Aristóteles.

Almeida Garrett foi um homem comprometido com a Revolução Liberal de 1820, um homem que, 
a favor da liberdade, luta contra a tirania. Daí que considere (1963: 739) que Plutarco deve ser lido, referindo-o explicitamente cerca de 20 vezes; daí que alguns dos retratados nas suas Vidas, lendários ou históricos, sejam nomeados, sobretudo na obra política e parlamentar. São da especial predilecção de Garrett Catão de Útica, Epaminondas, Temístocles, Aristides, Sócrates, Alcibíades, Fabrício, Bruto, ${ }^{1}$ Licurgo, os Gracos, Horácio Colces, Fábio, Cipião, Sertório, Coriolano ou Tito.

Cito apenas alguns passos dos muitos que nos dão essa visão paradigmática de figuras de Plutarco. Começo por uma citação retirada de um texto incluído em Política, em que Garrett - escrevendo em 1832, decorridos cinco anos de perseguiçóes dos absolutistas aos liberais, com prisóes e desterros, e desaparecidos muitos democratas de 1820 - refere restarem, apesar disso, alguns desses democratas que equipara a Aristides, a Catão, a Bruto (1963: I 1229):

(....) já bem pouco atidos às reminiscências das escolas, continuaram a ser Aristides, Catôes, e Brutos e nem sequer se lembraram de que sobre as cinzas desses varóes ilustres, cujas ideias eram inegavelmente progressivas na época em que eles viveram, pesavam já mais de dois mil anos. ${ }^{2}$

${ }^{1}$ Tanto pode ser Lúcio Júnio Bruto, a cujo exemplo recorre mais abaixo, como Marco Bruto, que os dois nomeia Garrett.

${ }^{2} \mathrm{O}$ passo é tirado dos "Estatutos da Sociedade Conservadora do Sistema Monárquico representativo em Portugal”, datados de 8 de Julho de 1841. 
Aristides, Catão, Bruto são todos heróis de Plutarco, como o são também os que aparecem citados em texto de género totalmente diverso, $O$ Retrato de Vénus, em que fala do descaminho que levam as artes (1963 II: 648):

Sem rumo as artes desgrenhadas fogem,

A Roma de Catão, de Augusto a Roma

Não é de Pio a efeminada corte;

E em vez de um Fábio tardador, de um Quíncio,

De um Bruto, um Mânlio; prostituta prole

No desonrado Capitólio avulta.

Catão, Fábio, Bruto, Mânlio são de novo figuras de Plutarco. Apenas mais uma citação, retirada dos Discursos Parlamentares - do que proferiu na Câmara de Deputados, na sessão de 8 de Fevereiro de 1840 (1963: II 1287 sqq.) - na qual voltam a surgir figuras das biografias de Plutarco. Reagindo à acusação de colaboracionismo feita na Câmara ao seu partido, Garrett verbera os que se aproveitam do regime e dos cargos para enriquecerem e afidalgarem e vêm acusar de 'bastardos' quem coopera - palavra que está na origem da acusação - com a monarquia; que adulam o povo na Câmara eà noite se sentam à mesa dos ricos, mas criticam os que, tendo-se denodadamente esforçado pela pátria e lutado pela liberdade, apontando sempre os erros e as deficiências, falam de colaborar e de "ordem que é razão e justiça»; a esses hipócritas críticos, compara-os Garrett ironicamente e por contraposição a figuras de Plutarco, 
devolvendo-lhes o epíteto de 'bastardos' e apelidando-os de «Gracos ridículos, de «Publícolas palhaços que ora se enfeitam da coroa cívica nos Comícios, ora das pérolas de barão feudal nos palácios», que, através da lisonja e da mentira, pretendem ter ao mesmo tempo «as honras de Catão e o poder de César», que sempre conseguem estar do lado do poder, já que é doce invocar o nome Jesus Cristo para lhe tosquiar o rebanho, em vez de o apascentar, e invocar o nome do Rei "para reinar mais que ele»; é doce dominar o povo pela lisonja e «dispor da força bruta» (1963: II 1296-1297):

(....) era mais doce ainda, mais suave que tudo, dominar as turbas com a lisonja; dispor da força bruta, que tanto mais serva e escrava é quanto mais cuida mandar; concentrar em si todos os direitos, monopolizar toda a liberdade para si só; - ter as honras de Catão e o poder de César; almoçar no foro os rábanos de Fabrício, e banquetear-se à noite nos temulentos palácios de Lúculo.

E a emprazadora da Ordem e os importunos dos Doutrinários a patentear ao Povo estes mistérios Eleusinos, a abrir diante dos seus olhos as austeras, as desenganadoras páginas da História, a mostrar-lhes aí como dos Gracos se fazem Catilinas, e dos Mários ditadores, como o tribuno se converte sempre em áulico, o publícola em palaciano, mal as turbas se fatigam de seu reinado nominal, e o Poder, por sua natural tendência, ou se concentra no feixe consular, ou na vara ditatória, ou no diadema imperial, ou no simples bastão do protectorato - em qualquer símbolo da Realeza que se destruiu mentindo, que mentindo se restabelece. 
Estendi um pouco a citação, porque ela permite, além de mostrar como Almeida Garrett recorre com mão assídua aos biografados de Plutarco, sobretudo a alguns deles - e nesta citação estão presentes os Gracos, Publícola, Catão, César, Fabrício, Luculo, Mário -, evidencia ainda quanto a cultura clássica está nele entranhada e com facilidade e naturalmente aparece na argumentação.

Catão de Útica é um desses heróis plutarqueanos apontados como paradigma, é inclusive o mais citado na obra de Garrett. Tomado sempre como símbolo da luta pela liberdade e contra a tirania, a esse nobre romano dedicou a tragédia Catão, em cinco actos. Elegendo como assunto os últimos momentos de vida do protagonista, que se identificam com a resistência das forças republicanas em Útica ao domínio de César, a peça culmina com o suicídio de Catão. São objectivos desta tragédia a exortação ao amor da liberdade e, ao mesmo tempo, incitação ao espírito de moderação e de respeito da lei. Já em outro trabalho mostrei o débito a Plutarco desta tragédia de Garrett, pelo que me limito agora a remeter para esse estudo e a sublinhar alguns aspectos. ${ }^{3}$ A vitória de César sobre Pompeu deixa em situação delicada os defensores da Roma livre que, agrupados em Útica em volta de Catão, se consideram o verdadeiro senado romano e decidem resistir aos desejos de César. Mas nem todas as figuras da peça - que, através dos diálogos e monólogos, se apresentam, manifestam e

${ }^{3}$ Vide F. C. Bordoy 2001: 291-304. 
descobrem os seus propósitos - têm lídimas intenções e, entre elas, há focos de traição: Catão, o homem estóico, honrado, impoluto, defensor acérrimo da liberdade que prefere a morte a submeter-se à tirania de César, pelo que se suicida no final, no Acto $\mathrm{V}$, consumada a derrota e ocupada Útica; Marco Bruto, jovem exaltado e sempre pronto a enfrentar César, ansioso mesmo em derramar o sangue do tirano, que na cena final Acto $\mathrm{V}$ e final da tragédia promete vingar-se matando o ditador, mesmo depois de saber que é seu filho; Mânlio, um homem moderado, conciliador e sensato que, por essa razáo, foi indevidamente tomado como o cavalo de Tróia das forças republicanas; Semprónio, um demagogo adulador da plebe que, por inveja e ódio a Catão, não só se coloca ao lado de César, procurando escancarar as portas de Útica ao exército do ditador, como tenta ainda aliciar algumas das parcas forças de defesa desse grupo de resistentes, como acontece no Acto III, de maneira fraudulenta, com o jovem rei da Númida, Juba, que tem por Catão uma adoração de filho e o apoia com o seu exército; o filho de Catáo, Pórcio, que admira o pai e acaba por encontrar a morte em consequência da traição de Semprónio; Décio, enviado de César e amigo de Bruto; e o Povo, sobretudo presente no último Acto pelo seu desespero, mas também pela confiança e estima por Catão.

Da leitura da tragédia, ressalta que a sua acção se baseia em grande medida na parte final do Cato Minor de Plutarco, débito que aliás o próprio Almeida Garrett confessa - bem como a Tito Lívio 
- nestas significativas palavras do "Prefácio da segunda edição" (1963 II: 1614):

O desanimador estudo do coraçáo humano, o fatal conhecimento das humanas paixóes, e de sua influência e acção nas revoluçóes políticas, o habilitaram para entender agora melhor o seu Tito Lívio e o seu Plutarco. Assim comentados pela experiência de dez anos de revoluçáo, estes dois grandes fanais da história antiga guiaram o autor da tragédia nas reformas que nela fez, no desenho de seus caracteres, e no colorido de muitas cenas...

E em estoutras da "Carta a um amigo", publicada na primeira edição, em que - justificando-se da acusação de ter imitado o Catão de Addison, publicado uns anos antes - Almeida Garrett, embora reconhecendo possuir o seu Catão «expressóes, versos inteiros imitados de Addison» (raros todavia), sublinha as diferenças entre as duas obras e considera que «a semelhança decerto mais a produziu a comum leitura de Plutarco do que nenhuma outra coisa» (1963: II 1615) e que trabalhou com base nas Vidas de Catão de Útica e de César (1963: II 1618):

Posso dizer que trabalhei conscienciosamente e com escrúpulo no aperfeiçoar deste drama, procurando sobretudo dar-lhe aquele sabor antigo romano que até já nos derradeiros escritores latinos estava perdido.... Para esse fim somente, para me familiarizar e pôr, como se fora de casa, com os meus autores, traduzi de Plutarco as vidas de Catão (o menor ou uticense) e de César. Pesa-me que os limites circunscritos do volume me não deixem inserir aqui 
ao menos a primeira. Julgar-se-ia melhor da sinceridade e boa fé com que procurei transfundir, em suco e sangue para a verdade dramática, a verdade e exacção histórica de que aqueloutra vive, isto é, a dos costumes e caracteres.

Quero ainda referir que, se o débito da tragédia Catão a Plutarco reside em especial na ambiência que Almeida Garrett transmitiu à sua peça e no modo como trabalhou as personagens, são também muitos os passos que apresentam significativas identidades com outros tantos trechos das Vidas de Plutarco. É o próprio autor a indicar, nas notas que pospóe à tragédia (1963: II 1745-1761), as fontes do seu Catão e os paralelismos existentes entre essa tragédia e a obra do biógrafo de Queroneia - ao todo enumera 22 passos que foram beber às suas Vidas Paralelas, remetendo para diversas delas.

Se, como vimos, as figuras de Plutarco são com assiduidade nomeadas e se na tragédia Catão a influência é clara, o filósofo de Queroneia está subjacente em outras obras e passos de Garrett que, neles, ora confessa o débito, ora declara que o imita e deve ser imitado, ora o refere. A presença e paradigma de Plutarco é sobretudo com insistência apontado no opúsculo $D a$ Educação, com cuja análise terminaremos estas observaçóes. Antes porém gostaria de abordar três outras ocorrências do nome do escritor de Queroneia, uma no discurso fúnebre em memória de D. Helena Feio de Sousa e Meneses Aranha (Janeiro de 1869), 
outra na "Carta de guia para eleitores" e a terceira num dos Discursos Parlamentares (respectivamente, 1963: I 1030, 1083 e 1267), todas elas e exaltarem Plutarco ou as suas figuras como modelo.

$\mathrm{Na}$ primeira das três referidas ocorrências, um discurso fúnebre em memória de uma jovem de dezanove anos, D. Helena Feio de Sousa e Meneses Aranha, ao exaltar a importância do recolhimento feminino, apresenta como paradigma a figura de uma matrona romana, possivelmente Cláudia, que equipara aos mais emblemáticos dos biografados de Plutarco (1963: I 1030):

Aquela matrona romana que ficou tão imortal como os maiores homens de Plutarco - no seu memorável epitáfio, o que se dizia dela? Que esteve em casa e que fiou na roca.

Embora sem a nomear, Garrett tem com certeza em mente a figura de Cláudia que apenas considera digno de ser especificado no seu epitáfio - além da sua fala aprazível e do seu gracioso andar, de amar o marido e criar os filhos - o cuidar da sua casa e o fiar a lã (Bücheler, C.E. 52). É bem possível que não esteja também de todo ausente a imagem de Lucrécia, descrita num conhecido passo de Tito Lívio 1. 57-60 que a apresenta a trabalhar a lã com as criadas, enquanto o marido combatia, e que, violentada pelo rei Sexto Tarquínio, se suicida, fazendo jurar ao pai, ao marido e a Lúcio Júnio Bruto que «o adúltero não ficará impune», juramento que está na origem da declaração 
do último de que não consentirá que nem os Tarquínios nem outra qualquer pessoa reinem em Roma, ponto de partida para a queda da monarquia. Tenha-se em conta que Lúcio Júnio Bruto - explicitamente apontado como exemplo no Da Educação, como veremos mais adiante - é um dos mais citados por Garrett e a luta contra a tirania e o despotismo uma das suas constantes.

Interessa sobretudo ao meu objectivo sublinhar que são os heróis das Vidas de Plutarco os paradigmas máximos a que Garrett equipara essa mulher romana ou seja, para utilizar as suas palavras acima citadas, «ficou tão imortal como os maiores homens de Plutarco».

No segundo passo, da "Carta de guia para eleitores" (1963: I 1073 sqq.), voltam a aparecer os'homens de Plutarco' - designação que genericamente Garrett lhes dá - como modelo maior. A determinada altura fala dos juízes e da independência que devem ter em relação ao poder político (1963: I 1083):

(....) para julgar é necessário que haja homens inteiramente isentos da influência ministerial, que não conheçam senão a lei, que não temam senão a ela, alheios a todas as paixóes, estranhos a todos os interesses. Enquanto estas duas estiverem cumuladas, façam os melhoramentos que quiserem, decretem as próprias leis de Platão, ponham em seus lugares todos os homens de Plutarco, nada fazem, nada reformam, nada melhoram e nada conseguem.

Esta soberania da lei e da justiça, que era um dos ideais gregos e também romanos, sublinhado em várias das figuras de Plutarco, é aqui exaltada e aplicada ao 
estado moderno e liberal. A mesma valoração da lei se encontra num passo de uma intervenção dos Discursos Parlamentares, proferida na sessão de 9 de Outubro de 1837, em que Garrett procura mostrar as vantagens e inconvenientes da nomeação régia ou da eleição popular, no que respeita à constituição da Câmara ou Conselho Revisor das leis aprovadas - uma espécie de Tribunal Constitucional de então. Garrett rejeita a Câmara ou Senado constituído por escolha do rei e prefere-lhe a eleição. $\mathrm{O}$ texto que a seguir se cita insere-se nos argumentos em que apoia essa rejeição da escolha pelo rei e fala das facçóes que então tudo dominavam (1963: I 1267):

Quem se atreverá a colocar nas máos destes seis eleitores privilegiados os destinos e esperanças da naçâo? Quando todos fossem táo virtuosos como seis homens de Plutarco, quando nestes seis portentos de sabedoria e integridade se refundissem os sete sábios da Grécia, como haviam eles, nos tempos calamitosos em que vivemos, evadir-se à influência omnipotente de qualquer facção que domine?

A presença de Plutarco é em especial significativa no opúsculo Da Educaçâo, um tratado pedagógico constituído por um conjunto de doze cartas endereçadas à rainha $\mathrm{D}$. Maria, nas quais procura sugerir a feitura de um manual educativo que, existente em outros países, Portugal ainda não possuía. Seria adaptado às diversas idades e sexos, começando na meninice - ou puerícia, para usar o termo de Garrett - até à idade adulta ou virilidade. 
Ao longo da exposição do opúsculo Garrett apresenta Plutarco algumas vezes como paradigma, embora declare na "Carta primeira" (1963 I: 687) - ao teorizar e apresentar o plano geral do livro e ao falar da autoridade das citaçóes e dos escritores - não «pretender examinar, um por um, os sistemas e os tratados de Aristóteles e Plutarco, de Fénelon e Rollin, de Rousseau e Helvécio, de Loke e Condillac, de Genlis e de tantos outros enfim antigos e modernos que da matéria trataram». Esta afirmação de Garrett poderia sugerir que teria em mente o De liberis Educandis - e não temos a certeza de que náo fosse esse o caso, já que traduzido para latim em Florença, em 1410, por Guarino Veronense (tradução publicada em 1471), esse tratado atribuído a Plutarco exerceu forte influência desde o Renascimento, com sucessivas traduçóes a aparecerem, quer em latim, quer nas línguas nacionais, e com diversos tratados de educação que o tomam como modelo. ${ }^{4}$

As referências posteriores, contudo, mostram que assim não acontece: são sobretudo as Vidas Paralelas que estão subjacentes e não o De Liberis Educandis. Assim, na "Carta Sexta" (1963: I 729740) propóe uma educação que - além de vários escritores modernos - tenha por base Fedro, Esopo, Plutarco, Valério Máximo e que estabeleça paradigmas de figuras históricas. A carta aborda a educação no

${ }^{4}$ Desde D.I Wittenbach 1820: 1-30 que este opúsculo tem sob suspeita a autoria e é considerado apócrifo. Para a influência e diversas traduçôes que o tratado teve em latim a nas línguas nacionais vide J. Sirinelli 1987: 3-6. 
final do segundo período etário, ou seja da passagem da puerícia à adolescência, considera a história como complemento moral dessa educaçáo, reflecte sobre o primeiro livro que se deve dar às crianças e prefere um que contenha paradigmas históricos gregos, romanos, de outros povos, mas sobretudo portugueses. É neste contexto de aconselhamento a escolher exemplos da história de Portugal que Plutarco volta a ser nomeado. Assim em determinado passo da carta (1963 I: 734) refere que as "grandes acçóes de virtude», os "feitos de valor e heroísmo de todo o género» - e também os "crimes e vícios e faltas - que os Portugueses praticaram ou cometeram desde a extremidade da Europa à África, à América e até aos confins da Ásia, dariam «matéria para muitos volumes de Valérios Máximos, Cornélios Nepotes e Plutarcos».

$\mathrm{Na}$ apresentação ou escolha dos exemplos, Garrett é explícito em declarar, em vários passos da carta, o seu débito a Plutarco. Apresento alguns deles. Depois de se referir à utilização das fábulas na educação - dissertando sobre o sentido etimológico do termo ${ }^{5}$ e citando Esopo, Fedro, La Fontaine - e de lhes apontar alguns inconvenientes, aconselha, de preferência, um livro com paradigmas históricos, à maneira do que fizeram Plutarco e Valério Máximo (1963: I 731):

${ }^{5}$ Escreve a tal propósito em 1963 I: 731: «Demais, fábula quer dizer fingimento; e fingimento é mentira; e mentira nem zombando se deve ensinar às crianças: é como brincos de lume, que a mais descuidada ama-seca lhes não permite». 
Um bom livro que contivesse - primeiro, histórias verdadeiras, bem escolhidas e tiradas das antigas e modernas crónicas, - segundo, vidas de homens célebres, uma espécie de Valério Máximo e Plutarco da mocidade, em que se achassem, não Gregos e Romanos somente, mas varóes ilustres de todos os povos, e principalmente nossos, - um livro tal preencheria todas as condiçóes que em vão se buscam nas fábulas. Epaminondas, Aristides, Sócrates, Alcibíades, Aníbal, Mitridates, Bruto, Fabrício, Catão, Tito - o próprio Nero - Atila, Teodorico, Rodrigo, Belisário, Alfredo, Henrique IV, Afonso-Sábio, Afonso Henriques, Egas Moniz, Nun'Álvares, Las Casas, Bartolomeu dos Mártires, Martim de Freitas, João de Castro, Albuquerque, Pacheco, o Infante Santo, Howard, Turenne, Fénelon, e mil outros de todos os tempos e naçóes, ensinarão, pelo menos, táo boa moral como a "comadre cegonha, o compadre rato" e outras distintas personagens das crónicas de Esopo e seus discípulos.

As reservas de Garrett em relação à fábula aparecem justificadas (1963: I 731) com o facto de tal termo querer «dizer fingimento; e fingimento é mentira; e mentira nem zombando se deve ensinar às crianças». Daí a sua preferência pelas personalidades históricas, em que as greco-romanas aparecem em plano de evidência. Às nomeadas a par de heróis de outras épocas e países, no passo citado, a carta acrescenta outras ao longo da exposição, a ponto de nos dar uma longa lista, na maioria, de figuras que aparecem em Plutarco: Epaminondas, Aristides, Sócrates, Alcibíades, Fabrício, Catão, Bruto, ${ }^{6}$

${ }^{6}$ Tanto pode ser Lúcio Júnio Bruto, a cujo exemplo recorre 
Licurgo, os Gracos, Horácio Cocles, Fábio, Temístocles, Cipiāo, Sertório, Coriolano ou Tito.

Refere depois que o livro, cuja feitura sugere, ainda não existe em português e propóe-se mostrar como se faria, experimentando compor um capítulo que poderia ter como assunto a Justiça (1963: I 734735). Ora o paradigma a que recorre é o de Lúcio Júnio Bruto, um dos heróis de Roma que aparece em Plutarco, em especial na Vida de Publícola - ou melhor, o seu acto de aplicar a justiça, sem acepção de pessoas, mesmo aos próprios filhos, implicados numa conspiração que, à traição, planeara devolver a cidade de Roma à monrquia, entregando-a de novo ao governo dos Tarquínios. Descobertos, presos e processados por tal crime, os conspiradores compareceram ante Lúcio Júnio Bruto, cônsul nesse ano, que os interrogou inclusive os próprios filhos. Provado e confessado o crime, "pronuncia a fatal sentença: "O crime está provado; os acusados são réus de alta traição: lictores feri, executai a sentença da república”». Não vacilou na sentença o cônsul, mas o seu amor de pai não foi capaz de assistir à execução, cobrindo o rosto com a toga para não ver as cabeças dos filhos que rolaram a seus pés. Estive a citar, quase, as palavras de Garrett. E este seu exemplo pode ter subjacentes os capítulos 3-7 da Vida de Bublicola de Plutarco e o passo do Livro II de $A b$ Urbe Condita de Tito Lívio em que o episódio vem narrado (2. 3-5). Embora o texto do autor português

mais abaixo, como Marco Bruto, que os dois nomeia Garrett. 
não coincida exactamente com nenhum dos dois - em nenhum deles se encontra o pormenor de cobrir o rosto -, está contudo mais próximo do de Plutarco que, pelo menos, explicita que o cônsul Lúcio Júnio Bruto se retirou para não assistir à execução dos filhos (Publicola 6. 4-5).

Almeida Garrett termina a carta citando o Emílio de Rousseau que, subvalorizando a história e historiadores modernos, manifesta predilecção pelos antigos e entre estes dá como modelo preferível Plutarco (1963: I 739-740), com esta conclusão de Emílio: «o meu homem cá para mim, é Plutarco». Transcrevendo esta afirmação, Garrett póe-lhe alguma moderação, embora o autor das Vidas Paralelas continue a aparecer como paradigma a imitar:

E eu por mim creio que nem Plutarco que é só biógrafo da Antiguidade, nem um Plutarco moderno, em que se juntassem com os Varôes ilustres de então os dos tempos de agora, devia ser o primeiro livro do educando. Factos memoráveis soltos é que devem compor a primeira parte desta antologia moral; na segunda virão mui propriamente as vidas inteiras, mas resumidas, de homens célebres antigos e modernos: essa sim, essa deve ser um Plutarco da mocidade».

$\mathrm{Na}$ "Carta Sétima” (1963: I 741-747), às duas secçóes da antologia moral, sugeridas na carta anterior e especificadas no passo acima transcrito, acrescenta «uma terceira parte para a educaçáo do soberano» que "será um Plutarco de Príncipes, uma colecção de vidas de reis, 
de imperadores e de chefes de Estado» (1963 I: 743), paradigmas que aconselha a ir buscar à história ao longo dos tempos, mas sobretudo às figuras da Grécia e de Roma, cuja escolha já está praticamente feita em Plutarco (1963 I: 744):

Dessa rica e variada história da Grécia e Roma, dessa história por excelência, em que não há virtude nem vício do coração humano que não tenha seu exemplar, está quase toda feita a escolha nas Vidas de Plutarco.

Garrett acrescenta que com Plutarco e «com Cornélio Nepote será fácil» a tarefa do organizador dessa antologia, mas considera que há necessidade de correcçóes pontuais - cortar «onde é longo para a atenção de tão poucos anos», "lançar mais espesso véu onde o muito nu da pintura ofenderia olhos tão inocentes», "rectificar uma ou outra opinião fabulosa» -, porque, conclui, "Os Paralelos de Plutarco não são ainda para esta idade» (1963: I 744-745). A educação a que se refere é a do fim da puerícia e passagem para a adolescência, idade que Garrett coloca entre os sete e os catorze anos.

A “Carta oitava” (1963: I 748-754), ao procurar aplicar a um príncipe de Portugal os princípios anteriormente estabelecidos, refere que, ao objectivo de recolha de exemplos destinados à referida antologia, a "crónica de uma família» é preferível à «história de um povo» e que «o plano de Suetónio, de Tácito e de Plutarco» serve «melhor que o de Tucídides e Tito 
Lívio» (1963: I 748). Ou seja, Plutarco continua como o paradigma que Garrett aponta para ser seguido na feitura dessa espécie de Tesouro ou Espelho de Príncipes.

E o polígrafo de Queroneia volta a ser apresentado como modelo na "Carta décima" (1963 I: 762-768), que aborda a questão da educação física e da educação feminina. Recorrendo à opiniáo de Rousseau e de Madame Campan, reflecte sobre o exercício intelectual e as disciplinas aconselháveis a desenvolverem «a memória e o entendimento» (1963: I 766-767), considerando que uma e outro "quase se cultivam ao mesmo tempo e por meios simultâneos», se bem que a primeira mais temporã do que o segundo. É neste contexto que, em sua opiniáo, terminada a aprendizagem da leitura e da escrita, se deve começar «a fazer transcrever e decorar pelo nosso educando alguns trechos escolhidos, fáceis, simples dos melhores autores». Em nota elucida (1963: I 767 n.2) que esses exercícios devem ser praticados a partir da antologia já antes sugerida, "na suposição de termos um livro histórico, um Plutarco segundo o descrevi nas cartas antecedentes». E assim mais uma vez é Plutarco que ocorre de imediato ao pensamento de Garrett e a obra que tem em mente e elege como modelo são as Vidas Paralelas, náo o tratado De liberis educandis.

Em conclusão, várias vezes Almeida Garrett se declara devedor de Plutarco ou o erige como seu paradigma. Além de nomear e apresentar como modelos muitos dos biografados das Vidas do polígrafo 
de Queroneia, sem dizer explicitamente que essa é a sua fonte, confessa abertamente em outros passos que está a imitar Plutarco ou sugere que ele seja o modelo a seguir. Tal torna-se evidente em especial no opúsculo $D a$ Educação. No entanto, quando se esperaria que Almeida Garrett tivesse em mente neste opúsculo o De Liberis Educandis - o Da Ecucação das Crianças - as mençóes de Plutarco são feitas sobretudo com o pensamento nas Vidas Paralelas e nas figuras aí apresentadas, a que Garrett apelida genericamente 'os homens de Plutarco'. 


\title{
A Tragédia Catáo de Almeida Garrett. Colmeita em Plutarco
}

\author{
José Ribeiro Ferreira
}




\section{A Tragédia Catáo de Almeida Garrett. Colmeita em Plutarco}

José Ribeiro Ferreira (Universidade de Coimbra)

O próprio Garrett afirma no prefácio da tragédia Catão que a sua composição muito deve à leitura e manuseamento da obre de Plutarco, em especial das «vidas de Catão (o menor ou uticense) e de César», "para me familiarizar e pôr, como se fora de casa, com os meus autores». Ora a comunicação procurará analisar esse débito, confessado, ao autor de Queroneia.

Almeida Garrett teve uma formação clássica e conhecia bem a história e a cultura da Grécia e de Roma antigas. Mesmo depois de, na abertura da Dona Branca, que cuja publicação coincide com a data de saída da primeira obra romântica, ter abjurado os «Áureos numes de Ascreu, ficçóes risonhas / Da culta Grécia amável» (1848) continuou a conviver com os clássicos. Sáo muitas as citações, alusóes e referências mesmo em obras emblemáticas do Romantismo, como As Viagens na Minha Terra e o Arco de Santana.

Desses autores clássicos, Plutarco é dos mais recorrentes, talvez apenas superado por Homero, Virgílio, Horácio e Aristóteles. ${ }^{1}$ Almeida Garrett foi

${ }^{1}$ Almeida Garrett 1963: 739 considera que Plutarco deve ser lido.

Nomeia Plutarco explicitamente cerca de 15 vezes, mas o polígrafo de Queroneia está subjacente num número considerável 
um homem comprometido com a Revolução Liberal de 1820, um homem que, a favor da liberdade, luta contra a tirania. Daí que alguns dos retratos nas Vidas de Plutarco sejam frequentemente nomeados. Catáo de Útica é um desses heróis que são apontados como paradigma de lutadores da liberdade contra a tirania. A esse nobre romano dedicou a tragédia Catão, em cinco actos, além de ainda o nomear em outras obras cerca de uma vintena de vezes. Cito apenas uma passo dos vários que nos dão essa visão paradigmática de Catão. Garrett refere que em 1832, decorridos cinco anos de perseguiçóes dos absolutistas aos liberais, com prisóes, desterros, tinham desaparecido muitos democratas de 1820, mas que, apesar disso, permaneceram alguns que são equiparados a Aristides, a Catão, a Bruto - todos heróis de Plutarco (1963 I: 1229):

alguns, e estes eram já bem pouco atidos às reminiscências das escolas, continuaram a ser Aristides, Catóes, e Brutos e nem sequer se lembraram de que sobre as cinzas desses varôes ilustres, cujas ideias eram inegavelmente progressivas na época em que eles viveram, pesavam já mais de dois mil anos. $^{2}$

A tragédia Catão - cuja primeira edição surge em 1822, em plena euforia da Revolução liberal de 1820, e a $2^{\text {a }}$ em 1830 significativamente alterada e espelhando

de referência aos seus biografados, lendários ou históricos.

${ }^{2} \mathrm{O}$ passo é tirado dos "Estatutos da Sociedade Conservadora do Sistema Monárquico representativo em Portugal”, datados de 8 de Julho de 1841. 
desencanto e conformismo - vai buscar o seu assunto aos últimos momentos de vida do protagonista que se identificam com a resistência das forças republicanas em Útica ao domínio de César - episódio que culmina com o suicídio de Catão. São objectivos desta tragédia a exortação ao amor da liberdade e, ao mesmo tempo, incitação ao espírito de moderação e de respeito da lei.

O Acto I informa-nos sobre a vitória de César sobre Pompeu, a situação delicada em que se encontram os defensores da Roma Livre, agrupados em Útica em volta de Catáo, e ainda sobre as esperanças de cada um nas decisóes da reuniáo que estão prestes a iniciar e que consideram o verdadeiro senado romano. Através de diálogos e monólogos as figuras apresentam-se, manifestam-se e descobrem mesmo os seus intentos: Catão, o homem estóico, honrado, impoluto, defensor acérrimo da liberdade que prefere a morte a submeter-se à tirania de César; Marco Bruto, jovem exaltado e sempre pronto a enfrentar César, ansioso mesmo em derramar o sangue do tirano; ${ }^{3}$ Mânlio, um homem moderado, conciliador e sensato; o filho de Catão, Pórcio, que admira o pai e acaba por encontrar a morte

${ }^{3}$ Garrett critica censura esta exaltação e violência que não trazem quaisquer resultados práticos. Assim na peça (Acto II, cena 1) Bruto aparece possuído de furor, de "heroísmo vão", de delírio que "Crimes perpetra por acçóes de glória». Para Catão, se é dever do homem honrado lutar pela libertação do país, não basta derramar o sangue do tirano para eliminar a tirania, como sublinha no Acto IV, cena 3:

.as cem frontes dessa hidra

Se reproduzem sempre, e dobram, crescem.

Por uma, que decepas, mil surgem. 
em consequência da traição de Semprónio, que, na tragédia, é um demagogo adulador da plebe e que, por inveja e ódio a Catáo, não só se coloca ao lado de César, procurando escancarar as portas de Útica ao exército do ditador, como tenta também aliciar algumas das parcas forças de defesa desse grupo de resistentes; Juba, o jovem rei da Númida que tem por Catáo uma adoração de filho e o apoia com o seu exército; Décio enviado de César e amigo de Bruto; e o Povo, sobretudo presente no último Acto pelo seu desespero, mas também pela confiança e estima por Catão.

O Acto II é quase todo ocupado com a assembleia desse grupo de romanos que vai decidir se devem aceitar o domínio de César ou resistir. E os mais exaltados defensores da guerra são o traidor Semprónio e Marco Bruto.

Perante a ameaça velada de Décio, todos gritam guerra, quando Catão pergunta à assembleia se prefere a paz de César ou continuar a luta. Semprónio é um dos mais exaltados e acérrimos defensores da não cedência. Eis palavras suas (cena 5 do Acto II):

Contas assim tão certo coa vitória?

Já súplices nos crês aos pés de César?

Já por escravos teus nos imaginas?

De nossas forças quem te disse o estado?

Temos armas, e braços de sobejo

Que essas temidas legióes rechassem. 
A que Catão responde que um «Romano, Semprónio, nunca mente» e que estão débeis, as muralhas são frágeis, "poucos moribundos soldados» as defendem, pelo que "pouco resta / Para a espada de César».

O primeiro vai mesmo ao ponto de, hipocritamente, gritar "liberdade ou morte" e de propor que nem sequer se receba Décio, enviado do ditador; e acaba por afirmar que a condescendência em escutá-lo discorda dos princípios de Catão. Mas este, que conhece bem Semprónio, denuncia-lhe a hipocrisia, verberalhe o fanatismo, considerando que nem merecedor é de suspeita (cena 4 do Acto II); de seguida apresenta a Décio as condiçóes para deporem as armas (cena 5 do Acto II): desarmar as legiôes, depor a púrpura, abdicar da ditadura, voltar à situação de simples cidadão, veremos adiante (p. $11 \mathrm{ou}$ ).

O Acto III é ocupado pela revelação de que Marco Bruto é filho de César e de uma irmã de Catão que o ditador desonrara e abandonara e pela tentativa de aliciamento fraudolento de Juba por parte de Semprónio que leva o jovem rei númida a colaborar com as forças atacantes, julgando estar a salvar Catão.

A Acto IV passa-se durante a noite com o ataque de surpresa das forças de César e a descoberta da traição de Semprónio. Marco Bruto, que pensara ser Mânlio o verdadeiro traidor, manifesta a sua incredulidade e expressa a sua confusáo nestas palavras (cena 3 do Acto IV): ao sublinhar que Semprónio nem pelas gracos era ultrapassado na veemência da oratória e 
Semprónio!... que - a Tibério já não digo,

Mas nem a Caio Graco na veemência

Do orar cedia, que à mais leve idea

De servidão bramia mais terrível!...

Catão faz-lhe ver que «o crime tem outro semblante», que não o de Mânlio, e aconselha-o a aprender «a ler no coração dos homens / Pelas linhas da fronte» e a desconfiar do muito "Zelo em palavras», porque «discreto, parco delas / É o verdadeiro amor da liberdade» (cena 3 do Acto IV). Entretanto Juba - que detectado o logro, lutara bravamente pela defesa de Útica - entra, com Pórcio moribundo e Semprónio algemado, e conta toda a traição deste último. Apesar da dor pela morte do filho, Catão não se vinga, nem permite que Marco Bruto e o povo matem o traidor; ordena, pelo contrário, que o lancem fora das muralhas, já que lhe pesa a liberdade e prefere os ferros do domínio de César.

$\mathrm{O}$ Acto $\mathrm{V}$ representa o desenlace final: Catáo, perante a chegada iminente dos exércitos de César, consola o povo em pânico, convence todos os outros a partirem e a salvarem a vida, pede a Marco Bruto que case com a sua filha Pórcia e, depois, suicida-se. Quando Décio chega com palavras de clemência da parte de César, encontra um Catáo agonizante e escuta da boca de Marco Bruto a promessa de vingança (cena final do Acto $\mathrm{V}$ e final da tragédia).

Ante a leitura da tragédia e o rápido resumo, acabado de fazer, ressalta o facto de a acção se basear 
em grande medida na parte final do Cato Minor de Plutarco. É o próprio Almeida Garrett que confessa o seu débito ao filósofo de Queroneia - bem como a Tito Lívio - nestas significativas palavras do "Prefácio da segunda edição" (1963: II 1614):

O desanimador estudo do coração humano, o fatal conhecimento das humanas paixóes, e de sua influência e acção nas revoluçóes políticas, o habilitaram para entender agora melhor o seu Tito Lívio e o seu Plutarco. Assim comentados pela experiência de dez anos de revolução, estes dois grandes fanais da história antiga guiaram o autor da tragédia nas reformas que nela fez, no desenho de seus caracteres, e no colorido de muitas cenas...

Acusado de ter imitado o Catão de Addison, publicado uns anos antes, Almeida Garrett, na "Carta a um amigo", publicada na primeira edição, sublinha as diferenças entre as duas obras, justifica as possíveis semelhanças e indica os passos imitados (1963: II 16211631). A tal propósito, refere que, apesar da muita disparidade, tem o seu Catão «expressóes, versos inteiros imitados de Addison", embora raros, porque umas são boas e outros belos. Considera, no entanto, que «a semelhança decerto mais a produziu a comum leitura de Plutarco do que nenhuma outra coisa» (1963: II 1615) que trabalhou afirmaçóes corroboradas pelo seguinte passo do "Prefácio da Terceira Edição" (1963: II 1618):

Posso dizer que trabalhei conscienciosamente e com escrúpulo no aperfeiçoar deste drama, procurando 
sobretudo dar-lhe aquele sabor antigo romano que até já nos derradeiros escritores latinos estava perdido... Para esse firm somente, para me familiarizar e pôr, como se fora de casa, com os meus autores, traduzi de Plutarco as vidas de Catão (o menor ou uticense) e de César. Pesa-me que os limites circunscritos do volume me não deixem inserir aqui ao menos a primeira. Julgar-se-ia melhor da sinceridade e boa fé com que procurei transfundir, em suco e sangue para a verdade dramática, a verdade e exacção histórica de que aqueloutra vive, isto é, a dos costumes e caracteres.

Se o débito da tragédia em análise a Plutarco reside em especial na ambiência que Almeida Garrett transmitiu à sua peça e no modo como trabalhou as personagens, sobretudo o herói de Útica, não se queda por aí. São muitos os passos que apresentam significativas identidades com outros tantos trechos das Vidas de Plutarco. E é o próprio autor do Frei Luis de Sousa que indica, nas notas que pospóe à tragédia (1963: II 1745-1761), as fontes do seu Catáo e os paralelismos existentes entre essa tragédia e a obra do biógrafo de Queroneia-ao todo enumera 22 passos que foram beber às Vidas de Plutarco, remetendo para diversas delas. $\mathrm{Na}$ impossibilidade de estudar, por escassez de tempo, todos os passos em que essa influência se manifesta, vou apenas analisar dois ou três deles. Comecemos pela Cena 1 do I Acto em que alude às forças que escaparam à derrota de Pompeu em Farsália e se vieram juntar aos parcos efectivos que se recolheram a Útica:

Nossas legióes tão poucas, tão cansadas, 
Fracos sobejos da fatal derrota

Do infeliz Pompeu.

Trata-se de um passo que pode ter subjcente os caps. 57 e 58 do Cato Minor de Plutarco e A Vida de Pompeu, como a próprio Garrett informa na nota $A$ à tragédia.

Na cena 2 do mesmo Acto (1963 II: 1645), em monólogo pronunciado por Mânlio, pergunta-se pela liberdade:

Liberdade! - Qu'é dela, a liberdade?

Quanta nos deram Mário e Sila? - Quanta

Nos daria Pompeu se triunfante

Com suas legióes Volvesse ao Tibre!

Roma, Roma, os teus dias são contados;

Tu queres um senhor: tê-lo-ás. Os Quíncios

Já não voltam. Sem honra, sem virtude,

Sem aquela pobreza santa e livre

De Fabrício, onde vai a liberdade!

Marco Túlio venceu a Catilina;

E hoje - molemente passeando

Em seus jardins de Túsculo, revendo-se

Em mármores de Atenas, manso e quedo

Filosofando vai.

Esta fala de Mânlio tem subjacentes passos ou informaçóes de várias vidas de Plutarco. Por exemplo, Pompeu, Pirro, Cícero.

Na Cena 4 do Acto II (1963 II: 1673), quando Décio, enviado de César, lhe vem propor amizade e paz da parte do ditador, Catão altivamente apresenta as suas condiçóes: 
Desarme as legióes, deponha a púrpura, Abdique a ditadura; à classe torne De simples cidadão, e humilde aguarde A sentença de Roma. - Então eu próprio,

Quanto inimigo fui, cordial amigo,

Seu defensor serei.

Este passo tem paralelismo com episódio semelhante que vem contado no Cato Minor de Plutarco (64. 7-9), em que Catão proclama que é César quem tem de pedir desculpas, mas aí os interlocutores de Catão são os Trezentos Senadores de Útica:

São os vencidos que devem suplicar e os culpados pedir perdáo. Ora eu nunca fui vencido, durante toda a minha vida; pelo contrário, fui mesmo vencedor, quanto o quis, e superei César em honradez e justiça. É, pois, César que se rebaixou e que foi vencido, já que, se ele negava antes que agia contra a pátria, agora reconheceu-se culpado, apanhado no acto de delito.

Mas não é apenas Plutarco que subjaz ao texto do Catão, também encontramos, num passo da Cena 2 do Acto V, a apar do débito ao Cato Minor, intertextualidades de Platão, sobretudo do Fédon teoria das ideias e da reminiscência, imortalidade da alma (1963: II 1719-1720):

Consolaste-me, Sócrates: não morre

Com este corpo o espírito que o anima. 
Já não me prendem dúvidas; fujamos

Do vil cárcere: a morte só é termo

Da vida, - da existência não... No íntimo

D'alma o pôs Deus o sentimento vivo

Da eternidade. Este viver continuo

De esp'ranças, este ansiar pelo futuro,

Este horror da aniquilaçáo, e o vago

Desejo de outra vida mais ditosa,

O que são? - Indistintas, mas seguras

Reminiscências da perdida pátria.

E saudades de voltar a ela.

Ver-te-ei, mansão dos justos! - O sepulcro

Não é jazigo é estrada. - Convenceste

A minha alma Platão

Mas mesmo estas referências encontram parcial explicação no Cato Minor de Plutarco, como se pode ver nos capítulos 68-70 que resumo: dizem esses capítulos que Catão se despediu com afecto do filho e amigos - o que fez desconfiar das suas intençóes - e em seguida começou a ler o Fédon de Platão (68.2), ou, como diz o texto de Plutarco, "o diálogo de Platão sobre a

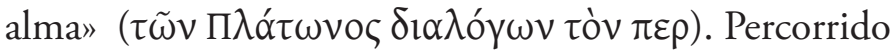
a maior parte do livro, levantou os olhos e não viu a espada no local onde a colocara - tinha sido retirada pelo filho, receoso do que pudesse intentar. Catão pergunta a um escravo quem tinha levado a espada e,

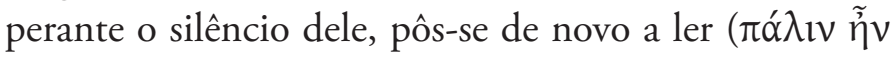

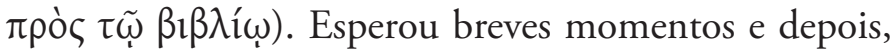
como se náo estivesse pressionado nem impaciente, ordenou que lha trouxessem. Perante a desobediência 
dos servos, exasperado começa a gritar que tinha sido

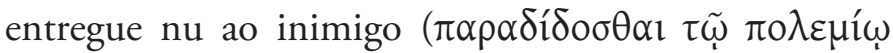
үupvòs) pelo próprio filho e pelos escravos. Pórcio acorre então, a chorar, com os amigos, e lança-se-lhe ao pescoço. E o pai, com ar severo, pergunta se acaso

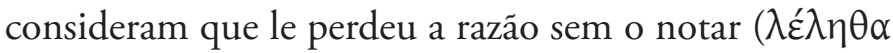

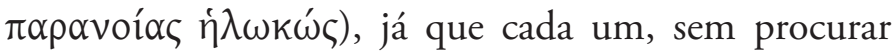
esclarecê-lo ou dissuadi-lo, o quer impedir de seguir a sua ideia e vontade. Diz por fim ao filho por que não lhe ata as mãos até que César chegue. $\mathrm{O}$ filho retira-se em lágrimas e, passados momentos, um escravo vem trazer a espada, que Catão examina. Certo de que estava em ordem, pega de novo no Fédon e continua a leitura antes de se suicidar. $\mathrm{O}$ médico, aproveitando o desfalecimento momentâneo de Catáo ainda tenta tratá-lo, suturando-lhe a ferida. Mas, ao recuperar a razão, o Uticense afasta-o e reabre-a.

O passo de Plutarco contém identidades com o de Garrett, mas não alude à teoria das ideias e da reminiscência, que aparece no autor português. Além disso, descreve o episódio da espada escondida e da tentativa de cura, de que Almeida Garrett se faz eco, mas em outro momento da acção - cenas 9, 10 e 11 do Acto V (1963 II: 1739):

Catão, quando vai agarrar na espada para se suicidar, não a vê no lugar em que a colocara. Então dirige-se com estas palavras duras a Mânlio, Marco Bruto e Juba: 
Que fizestes! Quereis ir entregar-me

Escravo, servo com as mãos atadas, Aos algozes de César, ou à infâmia

Pior, maior, do seu perdáo? Ingratos,

Vós meus filhos não sois: eu vos abjuro,

Vos renego.

Mânlio, comprometido - pois fora ele que escondera a espada - regressa com ela e entrega-lha. Catão então fere-se no peito e desfalece. Marco Bruto, Mânlio e Juba aproveitam a ocasiáo para lhe estancar o sangue. Ao voltar a si, pergunta por que o náo deixam morrer, lançando de imediato as mãos -á ferida e abrindo-a num último esforço.

A cena repercute o passo do Cato Minor de Plutarco em que o biografo, ao dar pela falta da espada, pede aos escravos que lha tragam. Perante a desobediência destes e do filho que a havia escondido, Catão exasperou-se e começou a gritar "que ele tinha sido entregue nu ao inimigo pelo filho e pelos escravos, até que seu filho, em lágrimas, acorreu com os amigos e, lançando-se-lhe ao pescoço, soluçava e suplicava» (68.4). Em seguida fere-se.

Vários outros exemplos poderíamos dar, mas o que atrás fica dito é suficiente para podermos concluir que, na tragédia Catão de Almeida Garrett, o débito a Plutarco é significativo e não se limita apenas à vida de Catão de Útica, mas estende-se a várias outras vidas. Apesar de presente em diversos passos, essa influência observa-se, no entanto, sobretudo na ambiência geral da peça e nas figuras. 


\title{
Plutarco em Oliveira Martins: O GÉNERO LITERÁRIO E A CONCEPÇÃO MORAL
}

\author{
Joaquim J. S. Pinheiro
}




\title{
Plutarco em Oliveira Martins: \\ O GÉNERO LITERÁRIO E A CONCEPÇÁO MORAL ${ }^{1}$
}

\author{
Johquim J. S. Pinheiro \\ (Universidade da Madeira)
}

A tarefa de analisar a presença de Plutarco na obra de uma figura marcante da cultura portuguesa do séc. XIX é um exercício extremamente interessante por, em primeiro lugar, patentear a pervivência do Queronense na cultura ocidental e, além disso, a própria concepção que Joaquim Pedro de Oliveira Martins (1845-1894) tem da história e da acção do homem, do tempo, das sociedades no evolver da história se aproximar das reflexóes que Plutarco desenvolve nas Vitae e nos Moralia.

Contemporâneo de figuras tão insignes como Antero de Quental, Ramalho Ortigão, Guerra Junqueiro e Eça de Queirós, Oliveira Martins, um verdadeiro autodidacta e sem qualquer formação universitária, tanto exerceu cargos político-administrativos, inclusive trabalhou em Espanha na administração das Minas de Santa Eufémia (Andaluzia), como foi, por exemplo, fundador de um jornal, $O$ Repórter. O percurso profissional de Oliveira Martins denota a diversidade dos seus interesses e a curiosidade do seu espírito, abrangendo domínios como a economia, a sociologia, a política ou a história. Além disso, a sua

${ }^{1}$ Expresso o meu agradecimento ao Professor Doutor José Ribeiro Ferreira por me ter sugerido o tema e pelo apoio prestado na sua concretização. 
actividade pública influenciará decisivamente a sua produção literária, partilhando, desde logo, duas características com Plutarco que não deixam nenhum leitor indiferente: a multiplicidade de temáticas e a reflexão profunda que fazem sobre o seu tempo e o devir histórico, com uma estreita ligação às suas experiências pessoais. $\mathrm{Na}$ verdade, se a produção literária de Plutarco não é alheia à circunstância histórica da Grécia pertencer ao imperium, ${ }^{2}$ também Oliveira Martins não é de todo indiferente a temas como o colonialismo, o Ultimatum ou a crise financeira, factos tão prementes numa sociedade decadente. ${ }^{3}$ Talvez por isso, resgatem

${ }^{2}$ A propósito do seu tempo, D. Placido 1995: 383, chama a atençâo para a contradiçáo que existe entre a tradição de independência grega com o tempo em que Plutarco vive: "El momento histórico que les correspondió vivir a los griegos cultos de la época de Plutarco, integrados satisfactoriamente dentro del Imperio romano, al tiempo celosos de preservar sus señas de identidad como herederos de la cultura clásica helénica, condiciono en gran medida su forma de pensar en el terreno de la política. Se daba la curiosa circunstancia de que la presencia imperial se contradecía objetivamente con la tradición de independencia de la pólis y que en ésta, en la cultura y en la historia política, sobresalía el momento democrático como modelo en torno al que los griegos disputaban ya desde la época en que estaba vigente el sistema mismo. Ello ofrecía serias contradicciones con el momento vivido y aceptado". (cf. A. Pérez Jiménez 2004: 50 sqq; os clássicos trabalhos de R. H. Barrow 1967: 43-50, 119-149 e de C. P. Jones 1971: 4864 e Part II; mais recentemente podemos referir duas obras que contextualizam as circunstâncias em que Plutarco escreveu as Vitae e os Moralia: J. Boulogne 1994, e S. Swain 1998r.

${ }^{3}$ A este repeito, F. Catroga 2004: 284, escreveu: "não reconhecer que a conjuntura condicionou a ênfase que lhe conferiu, seria olvidar que, para ele, a história, enquanto saber, só valia pelos efeitos morais que podia suscitar, e a biografia era o género historiográfico que melhor cumpria essa funçáo, como o aparecimento de revistas 
do passado heróis modelares, que só o espaço biográfico consegue expor, mediante a caracterização do ethos, num plano ético-psicológico.

Tendo em conta três obras da sua vasta produção, O Helenismo e a Civilização Cristã, Os Filhos de D. João I e A Vida de Nun' Álvares, ${ }^{4}$ percebe-se que Oliveira Martins não só tem conhecimentos sólidos da cultura clássica, como entende que a Antiguidade Clássica representa um período de criação verdadeiramente fundador e modelar, tendo consciência do sentido pedagógico dessa época e das suas influências no Ocidente. Aliás, o seu estudo O Helenismo e a Civilização Cristã, publicado pela primeira vez em 1878 , reflecte precisamente sobre o valor do contributo da Grécia à cultura europeia, tema que atendendo ao que escreve na "Introduçáo" considera de grande actualidade: ${ }^{5}$

"Achamo-nos com efeito numa segunda Renascença; e as energias, se na primeira revolucionaram a Europa, abraçando-se à tradição clássica, a essa mesma tradição hão-de tornar-se hoje para encontrar o princípio capaz de resolver o antagonismo das ideias, de debelar as cegueiras do empirismo, e concluir a crise de grosseira impiedade e torpe egoísmo (...)."

como o Plutarco Português (1881), ou de colecçóes como a que Latino Coelho escreveu sob a epígrafe Galeria de Varóes Ilustres de Portugal."

${ }^{4}$ Consultámos e citámos das ediçóes da Guimarães Editores, datadas, respectivamente, de 1985, 1993 e 1984 .

5 J. P. O. Martins 1985: 36. 
Umas páginas antes já havia deixado claro a importância que atribui à Grécia e ao Helenismo: ${ }^{6}$

"É porém o Helenismo e não outra coisa a base do pensamento moderno, pela razáo de que foi a Grécia, de entre as antigas civilizaçóes, a única onde a filosofia apareceu como centro e foro da vida moral. (...) porque foi a Grécia a primeira civilização que concebeu a ideia sobre todas clássica do homem livre.”

Para demonstrar a permanência dos valores e do pensamento da Antiguidade, Oliveira Martins alude à semelhança existente entre o pensamento e as formas de personagens da Antiguidade Clássica na cultura europeia: Napoleão III, sobrinho de Napoleão Bonaparte, repete Péricles; Voltaire sucedea Eurípides; Alexandre Herculano, "Velho-católico", ao "velho grego" Aristófanes; Kant não é mais do que Sócrates; Platão e Aristóteles são fundadores do pensamento e do temperamento; Strauss e Haeckel recuperam o materialismo de Demócrito, enquanto Proudhon bebe influências no estoicismo. ${ }^{7}$ Por sua vez, a D. Henrique, um dos filhos de D. João I, chama-lhe o "Cipiáo português", "Alexandre de uma espécie nova" $\mathrm{e}$ "o nosso Hércules". ${ }^{10}$

Este sinal de erudição surge também quando descreve acontecimentos da história de Portugal e os

${ }^{6}$ Ibid., pp. 19-20.

${ }^{7}$ Ibid., pp. 22-23.

${ }^{8}$ J. P. O. Martins 1993: 18.

${ }^{9}$ Ibid, p. 209.

${ }^{10}$ Ibid., p. 212. 
relaciona com acontecimentos da Antiguidade, como na tomada de Ceuta: ${ }^{11}$

"Alta noite, no silêncio palpitante do mar, a água marulhava contra o costado dos navios, reflectindo as luzes dos archotes que incendiavam a cidade, em terra, e essa outra cidade flutuante, em cujas muralhas de madeira estes povos novos gregos iam também, numa segunda Salamina, investir com a multidão dos bárbaros. Mouros ou persas, que importa? A História era a mesma: o choque violento da onda da Ásia, quebrando-se contra a resistência dos ocidentais. Essa maré que viera subindo desde os tempos de Dário e Xerxes, alastrava-se até à Espanha com os árabes.”

Mais impressionante, no entanto, são as múltiplas citaçóes, paráfrases ou simples alusôes a autores e textos gregos que podemos encontrar em $O$ Helenismo e a Civilizaçâao Cristã. Homero, Ésquilo, Sófocles, Heródoto, Xenofonte, Platão e, claro, Plutarco são os que merecem maior número de referências. No caso particular de Plutarco, Oliveira Martins mostra conhecer bem a obra do polígrafo de Queroneia. Fazendo uso da edição francesa de Alexis Pierron, datada de 1870, ou seja, publicada oito anos antes da sua obra, refere-se às Vitae cerca de cinquenta e quatro vezes, a maioria das quais à vida de Alexandre (37 vezes), enquanto os Moralia lhe merecem apenas três citaçóes, todas do tratado De superstitione. Das Vitae, refere-se aos seguintes bioi: Thes., Them. (três vezes), Arist., Cim.,

${ }^{11}$ J. P. O. Martins 1993: 49. 
Per., Nic., Alc., Cor., Dion (duas vezes), Pel., Alex., Lyc., Ag. e Cleom. (duas vezes). Temos, assim, referência a heróis do período clássico (Them., Arist., Per., Nic. e $A l c$.), do século IV a. C. (Pel., Ag., Dio e Alex.), do período helenístico ( $A g$. e Cleo.) e à biografia de Teseu, o fundador mítico de Atenas.

Note-se, ainda, que na maioria das vezes não cita o texto em tradução portuguesa, só fazendo referência à respectiva Vida e ao tomo da edição francesa, sem localizar a paráfrase ou a alusão. As muitas menções a Alexandre, o "Napoleão da Antiguidade", ${ }^{12}$ nas palavras de Oliveira Martins, devem-se ao facto de o Capítulo Sexto ter por tema "O Império de Alexandre", onde se explica a acção épica do macedónio. Havendo na Antiguidade vários autores que escreveram sobre a vida e os feitos do imortalizado rei macedónio, como Diodoro Sículo, Quinto Cúrcio Rufo e Arriano, não deixa de ser curioso que Oliveira Martins use a biografia plutarquiana como base para a sua reflexão e não faça alusão a nenhuma das outras.

Além deste conjunto de elementos, Oliveira Martins, em especial na "Introdução" da obra $O$ Helenismo e a Civilizaçâo Cristã, tece uma série de consideraçóes muito interessantes sobre a história, como arte e ciência. ${ }^{13}$ Entende ele que a história, tendo subjacente um progresso com destino, está dependente

${ }^{12}$ J. P. O. Martins 1985: 22.

13 Sobre a definição da concepção histórica de O. Martins merecem realce os trabalhos de M. de Albuquerque 1988: 9-80; P. Calafate 1990: 9-45; F. Catroga 1996: 117-136 e F. Catroga 2004: 243-288 e C. Maurício 2005: 19-154. 
da acção do homem, mas também do tempo, das naçôes e das raças. Ora, também em Plutarco a participação de cada um dos heróis nos combates, nas discussóes ou na politeia marca decisivamente a história. Por exemplo, Aristides e Temístocles, dois rivais, são indissociáveis das Guerras Medo-Persas. Torna-se evidente como tanto Oliveira Martins como Plutarco atribuem enorme significado aos efeitos da acção individual na sociedade. Como veremos mais à frente, a acção do Mestre de Avis ou de Nun'Álvares, além de marcar o seu tempo, condiciona a História do Povo Português. O mesmo processo ocorre, nas Vitae, com Péricles ou Alexandre.

Considera, ainda, que o "fortuito" tem um papel decisivo na determinação da história:

"Os casos fortuitos são na história infinitamente mais numerosos do que qualquer outra ciência. (...) Esta infinita multiplicidade de circunstâncias fortuitas tem dado e dará sempre à história, seja qual for a massa da erudição acumulada, um cunho próprio da sua superioridade." ${ }^{14}$

Equivalendo "fortuito" ao conceito grego tyche, estamos, também neste caso, perante uma matéria de reflexão muito presente na obra do autor de Queroneia: até que ponto o homem pode ser responsabilizado pelos sucessos e desventuras da sua vida política e militar? Preside, por exemplo, aos tratados De Alexandri Magni fortuna aut uirtute e De fortuna aut uirtute Romanorum ${ }^{15}$

${ }^{14}$ J. P. O. Martins 1985: 8.

15 Sobre estes dois tratados vide, inter alia, L. Pernot 1983: 
a preocupação de abordar esta questáo, estabelecendo-se a relação entre tyche e arete. ${ }^{16} \mathrm{O}$ sucesso deve apenas ser imputado à tyche? a uma divindade? $\mathrm{Ou}$ ao mérito humano (17 $^{17}$ Ora, quando náo consegue encontrar uma explicação clara e sustentada para um acontecimento, Plutarco atribui à tyche a sua causa. Assim, a tyche surge como uma força divina que actua na história dos homens, de acordo com as atitudes morais desses mesmos homens, tornando-se estes os sujeitos principais do seu destino.

Por fim, quando Oliveira Martins considera que o encontro dos povos faz a história, ${ }^{18}$ logo nos lembramos

121-9; S. Swain, 1989: 504-516; M. R. Cammarota, 1992: 105124; G. Anderson 1993: 114 sqq.; A. D’Angelo 1996: 115-124; M. R. Cammarota 2000: 69-86; F. Becchi 2000: 299-317; M. R. Cammarota 2002: 147-166; T. Duff 2002: 263-4; refira-se que se tem discutido sobre qual o período em que Plutarco escreveu este tratado e as implicaçôes daí decorrentes (Cf. C. Pelling 2002:1, n. 5 e 6 [=JHS 99 (1979: 74-96); B. Scardigli (ed.) 1995: 312-318] e vide ainda C. Pelling 2002: 84, n.63.

${ }^{16}$ Cf. Comp. Sol.-Pub. 3.5.; Phoc. 1.4-6, 3.1-4; Dio 1.3.

${ }_{17}^{17}$ Cf. Aem. 12.1-3; 24.1-4.

${ }^{18}$ Sobre a ideia de que o encontro dos povos faz a história, escreveu O. Martins 1985:11 as seguintes palavras: "o encontro dos diversos povos e suas civilizaçôes não é pois um mero acidente, senão a própria lei fundamental da história. Um povo isolado náo pode tirar de si e desenvolver senáo o que em si explicitamente contém; e só o encontro com outra civilizaçáo faz rebentar vivas e progressivas as forças latentes: por isso vemos pararem e como que cristalizarem aquelas naçôes a quem as circunstâncias fortuitas isolaram temporariamente do comércio dos demais povos. (...) desses encontros provém a sucessão das quedas e ressurreiçôes, das construçóes e das ruínas, do nascer, crescer e morrer dos impérios, dos esplendores deslumbrantes e das trevas espessas, dos dias e das primaveras, estios e Invernos que marcam a derrota dos astros do sistema da humanidade." 
do paralelismo cultural das Vitae, entre Gregos e Romanos, a base temática da produção de Plutarco. Sem dúvida que a história grega está marcada por diversos encontros - com o Oriente, com os Persas, com os Romanos e com outros povos da bacia do Mediterrâneo -e desses contactos se foi modelando a cultura helénica e, lato sensu, a cultura europeia.

Nas biografias, Os Filhos de D. João I $(1891)^{19} \mathrm{e}$ A Vida de Nun' Álvares (1893), podemos colher valiosos elementos sobre a concepção histórica e estabelecer paralelos com Plutarco. É precisamente na "Advertência" de Os Filhos de D. João I que Oliveira Martins, definindo os princípios do seu trabalho histórico-biográfico, se refere a Plutarco como um modelo: ${ }^{20}$

\begin{abstract}
"Nas vidas de Plutarco, temos ainda hoje, parece-me um dos modelos deste género literário: já porque assim o grego entendia a história; já porque fazia, como deve ser, da análise psicológica e do exame biográfico, o núcleo do estudo e observação dos tempos. A história tem nos caracteres como a pintura do retrato, o seu terreno de eleição; porque o homem com as suas crenças, ideias e até preconceitos e fábulas, foi o construtor da sociedade.”
\end{abstract}

Deste modo, percebe-se que Oliveira Martins não se limita a fazer referências ou citaçóes das Vitae, mas tem uma opiniáo esclarecida sobre o género literário usado por Plutarco. Tendo lido a biografia de Alexandre,

${ }^{19}$ Cf. A descrição dos filhos de D. João I e D. Filipa na p. 18 (cf. F. Catroga 2004: 284).

${ }^{20}$ J. P. O. Martins 1993: 8. 
como o provam as várias mençóes que lhe dedica na obra $O$ Helenismo e a Civilização Cristã, é natural que conhecesse a diferença que Plutarco aí estabelece no prólogo entre história e biografia: ${ }^{21}$

Ao escrevermos neste livro a vida do rei Alexandre e de César, por quem Pompeio foi derrotado, por causa do grande número de acçóes que servem de fundamento ao assunto, não diremos outra coisa em jeito de prólogo que pedir desculpa aos leitores que, se não contamos de forma exaustiva todos e cada um dos célebres feitos, mas resumirmos a maioria, não nos caluniem. $\mathrm{Na}$ verdade, nós não escrevemos histórias mas biografias, nem a demonstração da virtude ou do vício está, em absoluto, nas acçôes mais extraordinárias; pelo contrário, muitas vezes um acto insignificante, uma palavra ou uma brincadeira demonstram melhor o carácter do que os combates com inumeráveis mortos ou os maiores alinhamentos de exércitos e assédios a cidades. Tal como os pintores querem atingir as semelhanças a partir da face e da expressão dos olhos, que reflectem o carácter, preocupando-se muito pouco com o restante corpo, de igual modo nós devemos dar mais atenção aos sinais da alma e mediante estes representar cada vida, deixando a outros os feitos grandiosos e os combates.

Nesta espécie de declaração de princípios, Plutarco torna claro que não é sua intenção escrever histórias mas

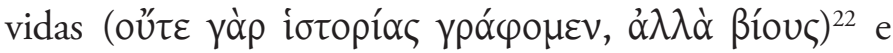

${ }^{21}$ Alex. 1.1-2; cf. Fab.16; Galb. 2.

${ }^{22}$ Apesar de aqui distinguir historia de bios, em Dem. 2.1, Cat. Mi. 12.1; Thes. 1.2, Nic. 1.5, Cim. 2.5, Fab. 1.1 e Aem. 1.1 chama historia ao texto que pretende escrever. Sobre este assunto vide A. 
que, além disso, o leitor - o aviso serve também para o actual leitor que deve ter em conta a intencionalidade de Plutarco, ainda que possa lamentar o facto dele nem sempre ter sido fiel no uso das fontes ou não ter sido mais preciso e exaustivo na identificaçáo de personagens ou no relato de acontecimentos que pululam os bioi - não deve esperar o relato completo dos grandes feitos, pois a virtude

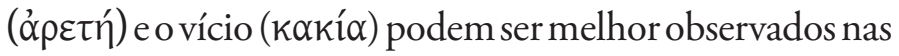
pequenas demonstraçôes do carácter humano. Também no prólogo do bios de Nícias, ${ }^{23}$ Plutarco lembra aos leitores que não tem a intenção de rivalizar com Tucídides ou Timeu, mas procurar pormenores que exemplifiquem o carácter e o comportamento do biografado, deixando de referir aquilo que não contribui para essa análise. Será, assim, a partir de pequenos episódios normais da vida quotidiana, muitas vezes anedóticos, ${ }^{24}$ num estilo próprio da Segunda Sofística, que Plutarco delineará o ethos. ${ }^{25}$

Feita a diferença básica entre o género histórico

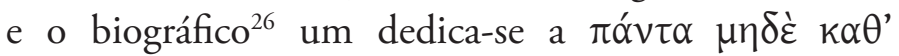

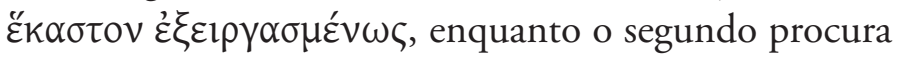

Momigliano 1991 (ed. original de 1971); E. Valgiglio 1987: 50-70; B. Gentile \& G. Cerri 1978: 7-27 e T. Duff, op. cit., p. 18 sqq; nos exemplos citados o termo historia parece estar mais próximo do sentido herodotiano de "pesquisa" do que de "obra histórica"; refira-se, ainda, que esta declaração é muito semelhante à de Políbio (10.21).

${ }^{23} 1.5$.

${ }^{24}$ Cf. N. I. Barbu 1976: 134 sqq.

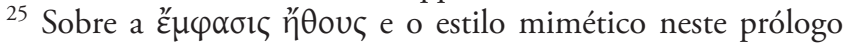
vide F. Frazier 1992: 4489 sqq.

${ }^{26}$ Cf. a distinção feita por Políbio entre biografia e história $(10.21 .8 ; 16.14 .6)$. 
$\varepsilon \dot{\pi} \imath \varepsilon \dot{\mu} \mu \nu 0 v \tau \varepsilon \varsigma \tau \grave{\alpha} \pi \lambda \varepsilon \tilde{\sigma} \sigma \tau \alpha$, o autor revela que tem dos factos históricos um indiscutível conhecimento mas que não está interessado em usá-los, de forma exaustiva, na sua produção literária, pois, como vimos, o seu objectivo é outro. Além disso, quando refere a sua intenção de aprofundar a análise dos sinais da alma ( $\tau \dot{\alpha} \tau \tilde{\eta} \varsigma ~ \psi v x \tilde{\eta} \varsigma$

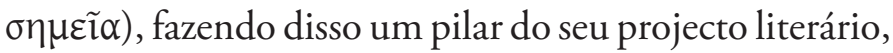
Plutarco inscreve também os seus retratos biográficos no campo psicológico. Como ele próprio confessa, o seu trabalho assemelha-se ao do pintor, ${ }^{27}$ que escolhe os traços que lhe parecem mais convenientes para ilustrar uma determinada pessoa ou a alma humana. Similarmente, Oliveira Martins considera-se um pintor quando escreve na "Advertência" da Vida de Nun'Álvares as seguintes palavras: ${ }^{28}$

27 No prólogo do par Cim.-Luc. 2.2, expressa a distância temporal que o separa das figuras biografadas e a relação disso com a verdade, seu objectivo, para terminar com uma comparação com o trabalho do pintor: "nós, ainda que muitas geraçóes nos separem, pensamos estender o agradecimento até nós, os que agora existimos, por julgarmos que a imagem mais bela é a que reproduz o corpo e a face, revelando o carácter e a conduta de vida. Por isso, retomaremos na escrita das Vidas Paralelas as acçóes desse homem, expondo-as com verdade. Este é um suficiente sinal de agradecimento. Nem ele próprio [Lucúlo] apreciaria receber uma recompensa que forjasse uma narraçáo falsa a favor dele, em vez de um testemunho verdadeiro. Como aqueles que pintam imagens belas e com muita beleza, ainda que tenham pequenos defeitos, nós julgamos não omitir, por completo, estes, nem os realçar. Pois isto ofereceria uma aparência deformada e diferente da realidade"; em Mor. 347 afirma que o melhor historiador é aquele que apresenta a narração como uma pintura de sentimentos e caracteres.

${ }^{28}$ J. P. O. Martins 1984: 7. 
“(...) a pintura sintética e dramática da vida de um dos seres colectivos chamados naçóes sugere ao espírito uma ideia muito mais nítida, real e duradoura, do que a narrativa sumária da sucessão de acontecimentos.”

Deste modo, ambos os autores comparam a sua arte biográfica à do pintor, ${ }^{29}$ pois também eles definem caracteres, seleccionando o que mais corresponde aos seus propósitos. Em Plutarco, como sabemos, a biografia política ${ }^{30}$ tem uma manifesta intenção moral e pedagógica, sacrificando-se muitas vezes a rigorosa metodologia historiográfica. De forma idêntica, a biografia de Oliveira Martins, que nem sempre prima pela clareza e precisão, ${ }^{31}$ tem um indiscutível alcance moral, até porque ele considera que "o que domina sobretudo a história são os motivos morais, e esses motivos parecem verdadeiros ou falsos conforme as eras e os lugares". ${ }^{32}$ A concepção que Oliveira Martins tem de Plutarco e do alcance moral da sua obra é evidenciado quando fala do saber de D. Duarte, o eloquente filho de D. João I: ${ }^{33}$

"Emigrando para fora dos claustros e despindo a cogula monástica, o saber, ao emancipar-se da tutela teológica

${ }^{29}$ Cf. J. Geiger 2000: 44-45.

${ }^{30}$ Expressão mais usada para designar a biografia plutarquiana, embora, como realça S. Fuscagni 2000: 22, e que nós reforçamos, não se pode entender com essa expressão que Plutarco seguisse uma objectiva estratégia política, mas apenas que a politeia e o seu exercício servem de base para a caracterização do ethos.

${ }^{31}$ Cf. C. Maurício 2005: 26.

32 "Advertência" de J. P. O. Martins 1993: 8-9.

${ }^{33}$ J. P. O. Martins 1993: 132-3. 
colocava-se na dependência da moral. Substituía ao transcendentalismo quase oriental um humanismo quase também inteiramente restaurado dos pensadores clássicos mais próximos dos modernos: Séneca, Marco António e Plutarco.”

Em relação ao objectivo pedagógico da sua escrita, Oliveira Martins revela-se um fiel seguidor do preceito historia magistra vitae: ${ }^{34}$

"Herdeiros das liçóes do passado, filhos de um mundo envelhecido, não podemos, é certo, repetir no seu objecto a devoção quase histérica dos santos medievais: mas havemos de aprender com os heróis, qual foi Nuno Álvares, de quanto o homem é capaz, desde que obedece aos impulsos generosos do seu coraçáo e aos movimentos decididos da sua vontade enobrecida."

Há ainda um elemento, muito versado pela crítica plutarquiana e pelos estudiosos da obra martiniana, que não devemos descurar: a dimensão psicológica. Em primeiro lugar, o efeito psicológico exercido sobre os ouvintes ou leitores e sobre a sociedade em geral, e num outro plano, a caracterização psicológica das personagens. Plutarco, como um atento observador do comportamento humano, analisa as suas causas e consequências, acreditando que uma formação baseada em valores e princípios, tais como a $\alpha \dot{\alpha} \delta \rho \varepsilon i ́ \alpha$,

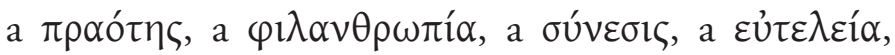

${ }^{34}$ J. P. O. Martins 1984: 314. 


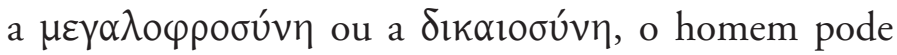
viver melhor e evitar os vícios que o levem a tomar atitudes que terão como fim a sua infelicidade. Note-se que os homens retratados por Plutarco, embora revelem diferenças entre si, têm um denominador comum: a energia que dedicam à sua missão de âmbito cívico. ${ }^{35}$ Aliás, só aqueles que têm princípios virtuosos e sentido de serviço pelo bem comum se deveriam dedicar à politeia. Em linhas gerais, aquele que dirige e assume o comando da politeia tem de fomentar a justiça e a concórdia, evitar os excessos e, acima de tudo, ser modelo de princípios, que só se podem ter pela paideia, na qual a filosofia assume especial relevo. ${ }^{36}$

Esta tendência para aplicar uma análise psicológica aos heróis, à qual os Antigos chamam ética, é reveladora do uso que faz do material histórico. A biografia de Plutarco junta feitos históricos e apreciaçóes morais, resultando desta fusão um modelo ético, assente numa conduta moral bem consolidada, ainda que por vezes um pouco complexa. ${ }^{37}$

Oliveira Martins, por seu lado, partilha desta concepção e não tem dúvidas em afirmar que a história é uma "arena amplíssima onde o artista e o erudito, o pensador e o crítico se encontram e se confundem, o jurista para indagar com escrúpulos, o psicólogo para analisar com subtileza.” Esta definição aplica-se quase

35 É curioso que o amor, elemento essencial no romance, surge nas Vitae como um obstáculo ao cumprimento dos deveres militares e políticos, como nos casos de Demétrio e António.

${ }^{36}$ Cf. An seni resp. ou Praec. ger. reip..

${ }^{37}$ Cf. J. Boulogne 1994: 60. 
por completo ao erudito de Queroneia, pois as Vitae têm não só a marca do tempo, como constituem um itinerário pelos valores, pela história, pela literatura e pelo pensamento da Antiguidade. À semelhança de Plutarco, também Oliveira Martins resgata heróis do passado (Nun’Álvares, Mestre de Avis e outros), que não são simples figuras ilustrativas ou estátuas ${ }^{38}$ do passado, mas têm alma e valores trans-temporais.

Ao escrever as biografias Os Filhos de D. João I e $A$ Vida de Nun' Álvares, torna objecto da sua obra um momento histórico, a Dinastia de Avis, ${ }^{39}$ decisivo na afirmação da consciência nacionalidade, recuando a uma época, nas suas palavras, "indecisa e confusa entre a tradição da Antiguidade culta e as lembranças actuais do viver desvairado nas guerras e depredaçóes". ${ }^{40}$

${ }^{38}$ Em Mor. 820B e E, Plutarco reprova a necessidade de se honrar alguém por meio de uma estátua, uma vez que suscitam a inveja, um dos grandes males da sociedade que se deve evitar, além de que as estátuas náo resistem ao tempo e podem sempre ser destruídas, como as de Demétrio de Falero; Cf. Cat. Ma. 19.6; Alexandre recusa que se faça uma imagem dele no Monte Atos (Trácia), pois serão as conquistas que imortalizarão o seu nome (cf. Mor. 335C-E).

39 F. Catroga 2004: 271-2: "Em Portugal, este climax foi atingido com a dinastia de Avis. Foi então que, inaugurando uma nova sociedade alentada pelas conquistas a Sul, e pela incorporação de novas populaçóes, os portugueses se voltaram para o mar. Só nesse momento a ideia de independência coincidiu com os interesses de toda uma regiáo, e se criou a força colectiva necessária para vencer a atracção centrípeta de Castela, lançando-se o país na aventura das Navegaçóes."; o mesmo autor lembra que O. Martins recorre à história de Roma como paradigma do apogeu e declínio da história de Portugal.

${ }^{40}$ J. P. O. Martins 1984: 237. 
Numa escrita densa, por vezes emocionada e repleta de referências a fontes históricas, Oliveira Martins evoca a acção dos seus heróis na defesa da pátria. Se olharmos, primeiramente, para a estrutura da Vida de Nun'Álvares, aquela que mais interessa ao nosso estudo, verificámos que apresenta uma sequência muito semelhante à das biografias de Plutarco: o genos, a paideia, a iniciação na politeia aos treze anos, desenvolvimento da politeia, os últimos anos de vida e a morte.

Da caracterização de Nun'Álvares, o Condestável, merecem realce diversos elementos. Comecemos por citar um texto elucidativo do seu ethos: ${ }^{41}$

"Com a sua alma temperada pela educação ideal da Cavalaria, não o seduziam, nem o consolavam, as carícias do lar, o brando sossego dos campos, o esquecimento das coisas, deixando-se vegetar a compasso com o correr das águas e o crescer das árvores, numa inércia abandonada. Ferviam-lhe no peito ardores insaciados e no cérebro dançavam-lhe visóes de desespero. Via-se aniquilado para sempre, inteiramente. E não era um homem que sucumbia: era um povo inteiro, a honra de uma naçáo: o sentimento heróico da Pátria portuguesa que o abrasava, fazia-o parecer doido ao comum da gente, afogada em cálculos da intriga, nos impulsos da cobiça, ou nos acessos, da ambiçâoo mesquinha. (...) surgia nele e com ele o sentimento novo da Pátria portuguesa. (...) Nem mulher, nem vaidade, as duas raízes mais profundas da acção humana, podiam dominá-lo...”

${ }^{41}$ Ibid, pp. 69-70. 
Desde logo, a ênfase colocada no seu patriotismo e no seu serviço e sacrifício pelo colectivo, permanecendo um espírito independente. De igual modo, na biografia de Aristides, filho de Lisímaco, o amor pela pátria assume-se como a temática central. ${ }^{42}$ Tal como do estratego Filopémen, "o último dos gregos", se constrói um retrato que frisa o seu amor pela Grécia e pela liberdade. Contudo, na biografia de Fócio, com uma perspectiva diferente, se faça notar que o patriotismo exacerbado é muitas vezes nocivo e inoportuno.

Pouco dado a discursos, Nun'Álvares assumia-se, sobretudo, como um homem de combate e comando (philonikia), ${ }^{43}$ imprimindo nos seus seguidores disciplina e coragem. Por causa disso, na célebre batalha de Aljubarrota consegue persuadir um exército em inferioridade numérica a combater o inimigo todopoderoso.

Nos momentos de conflito, servem-lhe de modelo as tácticas de Viriato e Sertório. ${ }^{44}$ Esta não é a única vez que se estabelece paralelo com personagens da

42 Há quem veja na decisão de Plutarco em continuar na Queroneia (cf. Dem. 2.1-2) uma atitude patriótica e uma ligação íntima à terra dos seus ancestrais; cf. Mor. 792 E-F (o dever de regressar à pátria).

43 Cf. "Queria ir, queria bater-se, queria morrer!" J. P. O. Martins 1984: 64.

44 "Renasciam-lhe na ideia as invençôes remotas de Viriato, ou de Sertório." (ibid., p. 131) e “(...) e porque, nesse foco de resistência à conquista, estava de pé armado Nuno Álvares, o invencível, que não vergava ao peso de nenhum desânimo, e em cuja ideia a defesa do reino consistia numa ofensiva temerária, e a táctica salvadora na repetição das ignoradas façanhas de Viriato e de Sertório" (ibid., p. 151). 
Antiguidade, pois também quando Nun'Álvares entra em território castelhano, Oliveira Martins escreve: ${ }^{45}$ "Como Aníbal na Itália, seguia Nuno Álvares talando os campos: nas serras, o Barbuda [Martim Anes] repetia Fábio Máximo, o cunctator, esperando a desforra que não veio." Para se atingir a vitória, Oliveira Martins considera que "a virtude e a candidez de alma eram condiçôes indispensáveis ao êxito”, no fundo, dois conceitos, a arete e a praotes, que ilustram bem o pensamento de Plutarco.

Descrevendo Nun' Álvares como um homem que respeita o inimigo e divide os despojos de guerra com os companheiros, hábil, sagaz, destemido, íntegro, fiel aos princípios e enérgico nos objectivos, Oliveira Martins aproxima-se, talvez de forma inconsciente, da caracterização do herói das Vitae, ainda que na parte final da biografia, após as lutas pela defesa da pátria, a figura do Condestável atinja uma dimensão religiosa e mística, que não se encontra nos heróis de Plutarco. No entanto, em relação às outras qualidades, fazem recordar, a título de exemplo, a habilidade de Sertório, as virtudes guerreira e a simplicidade de Filopémen, a humanidade de Flaminino, a sensibilidade de Marcelo ou a moderação de Numa.

Conclui-se que Oliveira Martins usa a obra de Plutarco para clarificar a sua concepção de história e, além disso, ao mencioná-la variadíssimas vezes indicanos que lhe atribui um papel relevante no contexto

${ }^{45}$ J.P. O. Martins 1984: 212. 
helénico e, em consequência disso, torna-se um dos pilares da presença clássica no Ocidente. À semelhança de Plutarco, faz do passado, ou seja, do conflituoso tempo de Avis, o centro da sua narrativa, de forma a iluminar o tempo presente. Ambos partilham a visão de que a história se repete ${ }^{46} \mathrm{com}$ sinais e protagonistas distintos. Nesse sentido, estudar, aprofundar e conhecer os "sinais da alma" e o ethos de figuras do passado significa ter consciência histórica e cultural.

${ }^{46}$ Vide, por exemplo, em Sert. 1.1. a reflexão sobre o tempo que passa com acontecimentos que se repetem. Ora, este não é mais do que um topos da historiografia grega (Cf. e.g. Tuc. 1.22.4), que prova a sua utilidade a partir da análise dessas repetiçôes históricas, apontando causas e consequências. 


\section{Bibliografia}

\section{EDIÇÓES, TRADUÇÓES E COMENTÁRIOS}

V. Alfieri (1965), Vita. Opere. Introduzione e scelta a cura di V. Branca. Milano.

M. Condorcet (1968 reimp.), Oeuvres I/II/III/VII. Stuttgat.

G. D’Annunzio (1960), La vita di Cola di Rienzo. Milano.

U. Foscolo (1995), Ultime lettere di Jacopo Ortis. Testo stabilito e annotato da M. A. Terzoli in F. Gavazzeni et al. (eds) Opere. 2. Prose e saggi. Torino.

A. Garrett (1963), Obras de Almeida Garrett. Porto.

N. Machiavelli (1971), Discorsi sopra la prima Deca di Tito Livio, Tutte le opere. A cura di M. Martelli. Firenze.

J. P. O. Martins (1984), A Vida de Nun'Álvares, Lisboa.

—_ (1985), O Helenismo e a Civilização Cristã. Lisboa.

_ (1993), Os Filhos de D. João I. Lisboa

M. Robespierre (1973), La revolución jacobina (trad. esp.). Barcelona.

Mme Rolland (1827), Mémoires. Paris.

J. Sirinelli (1937), Plutarque, Oeuvres Morales I. 1. Paris. SaInT-Just (1968), Fragments in Oeuvres choisies. Paris. 
A. Soboul, ed. (1977), Oeuvres de l'Abbé Grégoire. Liechenstein.

A. Soвoul, ed. (1980), Desmoulins. Oeuvres X. München.

G. Vico (1971), Opere filosofiche. Introduzione di $\mathrm{N}$. Badaloni, testi, versioni e note a cura di P. Cristofolini. Firenze.

B. de Warville (1911), Mémoires (1754-1793) publiès avec étude critique et notes par $\mathrm{Cl}$. Perroud. Paris.

\section{Estudos:}

A. Adler (1975), "J. Amyot preceptor of two king's", Renaissance News 10, 3: 131-138.

L. B. Alberti (1843-1849), De iciarchia, in Opere volgari, Bonucci (ed.), vol. III. Firenze.

F. Albini (1977), "Family and the formation of character in Plutarch", in Plutarch and his intellectual world, Judith Mossman (ed.). London.

M. de Albuquerque (1988), "Oliveira Martins historiador", in J. P. O. Martins, História de Portugal. Lisboa, 9-80.

G. Anderson (1993), The Second Sophistic. A Cultural Phenomenon in the Roman Empire, London and New York.

A. A. de Andrade (1965), Antologia do pensamento político português (séc. XVI), $1^{\circ}$ vol.: Periodo Joanino, 
in Separata de Estudos politicos e sociais, III n. 2 e 3. Lisboa.

D. P. de Andrade (1630), Casamento perfeito em que se contem advertências...para viverem os casados em quietação...\& muitas hystorias, \& acontecimentos...dos tempos antigos, \& modernos... com varias sentenças, \& documentos de autores gregos, \& latinos. Lisboa, Jorge Rodriogues.

A. Asor Rosa (1998), "Il tempo dei classici", Critica del testo 1 53-84.

R. Aulotte (1965), Amyot et Plutarque. La tradition des Moralia au XVI siècle. Genève.

- (1971), Plutarque en France au XVIe Siècle (Trois Opuscules Moraulx traduits par Antoine du Saix, Pierre de Saint-Julien et Jacques Amyot). Paris.

F. C. Babbitt, ed. (1949), Plutarch's Moralia. Cambridge, Mass.

N. I. Barbu (1976), Les Procédés de la peinture dès caractères et la vérité historique dans les biographies de Plutarque. Rome.

J. de BARros, Espelho de casados pelo Doctor João de Barros, $2^{a}$ edição conforme a de 1540, publicada por Tito de Noronha e António Cabral (1874). Porto, Imprensa Portuguesa

R. H. Barrow (1967), Plutarch and his Times. Oxford.

M. Bataillon (1961), «La Célestine» selon Fernando de Rojas. Paris. 
- (1966), Erasmo y España. Estudios sobre la historia espiritual del siglo XVI. México-Buenos Aires.

A. Battistini, E. Raimondi (1984), "Retoriche e poetiche dominanti", in A. Asor Rosa (dir.) Letteratura italiana. 3. Le forme del testo. I. Teoria e poesia. Torino, 5-339.

F. Becchi (2000), "La Nozione di TYXH in Plutarco. Una Variabile Secondo il Genere?”, in I. Gallo e C. Moreschini (eds.), I Generi Letterari in Plutarco (Atti de VIII Convegno plutarcheo, Pisa, 2-4 giugno 1999). Napoli, 299-317.

F. A. DE BEJA, Breve doutrina e ensinança de principes. Repr. fac-similada da ed. de 1525. Introduçáo de Mário Tavares Dias (1965). Lisboa.

J. Benthley (1987), Politics and culture in Renaissance Napoles. Princeton.

D. Bigalli (1989) "La città e gli oceani. Linee di raporti tra toscana e Portogallo nella prima età medicea”, in Studi e ricerche (nuova serie), I, Davide Bigalli (ed.). Bari: 65-117.

G. Billanovich (1947), Il Petrarca letterato. Lo scrittoio del Petrarca. Roma.

S. Bongi (1890), Annali di Gabriel Giolitto de' Ferrari da Trino di Monferrato, stampatore in Venezia. Roma, 2 vol.

C. Bontems et alii (1965), Le prince dans la France des XVIe et XVII siècles. Paris 
F. C. Bordoy, ed. (2001), Misticismo y religiones histéricas en la obra de Plutarco. Actas do VII Simposio Español sobre Plutarco. Palma de Mallorca.

J. Boulogne (1994), Plutarque, Un Aristocrate Grec sous l'occupation romaine. Lille.

V.Branca ( ${ }^{2}$ 1994), "Barbaro, Ermolao [....] el'Umanesimo veneziano", in Dizionario critico della letteratura italiana. Roma, 1: 194-199.

A. Buck (1980), L'eredità classica nelle letterature neolatine del Rinascimento, trad. ital., Brescia.

M. L. C. Buescu (1971), João de Barros, Gramática da lingua portuguesa, Diálogo em louvor da Nossa linguagem e Diálogo da Viciosa Vergonha. Lisboa.

F. Buisson (1887), Dictionnaire de pédagogie et d'instruction primaire. Paris, s.u. Princes (Éducation des): 2435-2436.

P. Burke (1987 3a ed.), The Italian Renaissance culture and society in Italy. Cambridge.

P. Calafate (1990), "Aspectos da projecção da obra de Oliveira Martins”, in Oliveira Martins. Lisboa, 9-45.

M. R. Cammarota (1992), "Il De Alexandri magni fortuna aut virtute come espressione retorica: il panegirico", in Italo Gallo (ed.), Richerche Plutarchee. Napoli, 105-124.

(2000), "La tradizione retorica in tre declamazioni di Plutarco: De Alexandri Magni Fortuna aut virtute, De fortuna Romanorum, De gloria Atheniensium”, 
in L. Van der Stockt (ed.), Rhetorical theory and praxis in Plutarch (Acta of the IVth International Congress of the International Plutarch Society, Leuven, July 3-6, 1996). Louvain/ Namur 2000, 69-86.

_ (2002), "Nota al De Fortuna Romanorum Di Plutarco", in L. Torraca (ed.), Scritti in onore di Italo Gallo. Napoli, 147-166.

F. Catroga (1996), "História e ciências sociais em Oliveira Martins", in Luís Reis Torgal et al. (eds.), História da história em Portugal. Sécs. XIX-XX. Lisboa, 117-136. - (2004), “O Magistério da História e a Exemplaridade do 'Grande Homem'. A Biografia em Oliveira Martins”, in A. Pérez Jiménez, J. Ribeiro Ferreira \& Maria do Céu Fialho (eds.), O Retrato e a Biografia como Estratégia de Teorização Política. Coimbra, 243-288.

J. Сhomarat (1981), Grammaire et rhétorique chez Erasme, 2 vols. Paris.

M. A. Cortelazzo (1984), Profilo dei dialetti italiani. Pisa.

P. Cerchi (1984), “Giovan Bernardo Gualandi: per la fortuna di Erasmo in Italia”, in G. P. Basin et al. (ed.), Studies in the Italian Renaissance. Essays in Memory of Arnolfo B. Ferruolo. Napoli, 208-225.

G. Chappuys (1583), Dialogues Philosophiques et très utiles italiens-françois, touchant la vie civile...Traduits de M. Jan Baptiste Giraldi Cynthien, par Gabriel Chappuys. Paris. 
A. D’Angelo (1996), “Analisi formale e critica del testo nel De Alexandri Magni fortuna aut virtute, or. I Plutarcheo", in. J. A. Fernández Delgado and F. Pordomingo Pardo (eds), Estudios sobre Plutarco: Aspectos Formale (Actas Del IV Simposio Español Sobre Plutarco. Salamanca, 26 a 28 de Mayo de 1994), Salamanca, 115-124.

T. De Mauro (1999), Storia linguistica dell'Italia unita. Roma.

G. Defaux (1973), Pantagruel et les sophistes. Contribution à l'histoire de l'Humanisme Chrétien au XVième Siècle. La Haye

P. Demerson (1983), "L'amour dans le «Leal Conselheiro» de Dom Duarte", in Arquivos do Centro Cultural Português, 19: 483-500.

P. Desideri (1992), "I Documenti di Plutarco", $A N R W$ 2.33.6 4536-4567.

G. Devoto (2002), G. Giacomelli, I dialetti delle regioni d'Italia. Milano.

F. Díaz-Plaja (1960), Griegos y Romanos en la Revolución francesa. Madrid.

J. Dillon (1977), "Plutarch and the end of history", in Judith Mossman (ed.), Plutarch and his intellectual world world. London.

C. Dionisotti (1999), Geografia e storia della letteratura italiana. Torino.

M. L. Doglio (1993), "Il Capra, i classici e le donne”, in Il 
secretario e il Principe. Studi sulla letteratura italiana del Rinascimento. Alessandria, 71-100.

U. Dotтi (2004), Vita di Petrarca. Roma.

T. Duff (2002), Plutarch's Lives: Exploring Virtue and Vice, Oxford.

V. Ehrenberg (1964), Society and Civilization in Greece and Rome, Cambridge, Mass.

Erasmo 1961-1962 (ed.): Erasmi Desiderii Opera omnia (in decem tomos distincta). Recognovit Joannes Clericus, Leiden 1703. Univeränderter reprographischer Nachdruck. Hildesheim [cit. L.B].

A. R. de Évora (1983), Sentenças de diversos autores pelas quaes amoestão aos príncipes como na paz e na guerra se devem reger, dirigidas ao muito esclarecido Principe Dom Sebastião, neto do mui Poderoso rei Dom João, Terceiro deste nome, nosso Senhor. Fac-simile do Manuscrito inédito da Casa Cadaval. Ed. de Luís de Matos. Lisboa.

D. Faure (1960), L'éducation selon Plutarque d'après les «Oeuvres morales», 2 vol. Aix-en-Provence

L. Febvre (1944), Amour sacré, amour profane. Autour de l'Heptaméron, Paris.

M. L. C. Fernandes (1984), "Da doutrina à vivência: amor, amizade e casamento no "Leal conselheiro» do rei D. Duarte", in Revista da Faculdade de Letras do Porto-Linguas e Literaturas, II série, vol. I: 133-194.

A. E. V. Fernández (1999), "Límites del influjo platónico 
en el Peri Paidôn agôgês", in Plutarco, Platón y Aristóteles - Actas del V Congreso Internacional de la I. P. S. (Madrid-Cuenca, 4-7 de Mayo de 1999). Madrid: 501- 514.

J. R. Ferreira (1988), "Grécia e Roma na Revolução Francesa", Revista de História das Ideias 10 203-234.

E. Franceschini (1962), "Aristippo, Enrico", in Dizionario biografico degli italiani. 4. Roma, 201206.

F. Frazier (1992), “Contribuition à l'étude de la composition des 'Vies' de Plutarque: l'élaboration des grandes scènes”, ANRW 33.6 4487-4535.

R. Fubini (1979), "Castiglionchio, Lapo», in Dizionario biografico degli italiani. 22. Roma, 44-51.

S. Fuscagni (2000), "Le Vite Parallele come genere letterario ovvero Plutarco: uno storico e il suo genere", in I. Gallo e C. Moreschini (eds.), I Generi Letterari in Plutarco (Atti de VIII Convegno plutarcheo, Pisa, 2-4 giugno 1999). Napoli, 19-28.

I. Gallo, C. e Moreschini, eds. (2000) I Generi Letterari in Plutarco (Atti de VIII Convegno plutarcheo, Pisa, 2-4 giugno 1999). Napoli.

E. GARIN (1958), Il pensiero pedagogico dello Umanesimo, Firenze.

- (1970) "La letteratura degli umanisti", in E. Cecchi e N. Sapegno (dirs.), Storia della letteratura italiana. 3. Il Quattrocento e l'Ariosto. Milano, 51 e sqq. 
J. Geiger (2000), "Political Biography and the Art of Portraiture: some parallels", in I. Gallo e C. Moreschini (eds.) I Generi Letterari in Plutarco (Atti de VIII Convegno plutarcheo, Pisa, 2-4 giugno 1999). Napoli, 39-45.

B. Gentile \& G. Cerri (1978), "L'idea di biografia nel pensiero greco", QUCC 27 7-27.

G. B. Gerini (1896), Gli scrittori pedagogici Italiani del secolo decimoquinto, Torino.

V. R. Giustiniani (1961), "Sulle traduzioni latine delle Vite di Plutarco nel quattrocento", Rinascimento 1: 3-62.

R. Gonçalves (1557), Dos priuilegios \& praerogatiuas qo genero feminino te por dereito comu \& ordenaçóes do Reyno mais que ho genero masculino. Apud Iohanne Barrerium Regium Typographum, Anno Domini 1557.

Frei Luís de Granada, Ecclesiasticae rhetoricae siue de ratione concionandi libri sex (Olyssipone, 1576), trad. espanhola: L. De Granada (1945), Los seis libros de la Rhetórica Eclesiástica, III, Madrid.

J. Griffin (1977), "The Epic Cycle and the Uniqueness of Homer”, Journal of Hellenic Studies 97 39-53.

M. Guglielminetti (1986), "Biografia e autobiografia”, in A. Asor Rosa (dir.), Letteratura italiana. 5. Le questioni. Torino, 829-886.

M. J. Guillaume (1894), Procès-verbaux du Comité d'Instruction Publique de la Convention Nationale. Paris. 
L. Guillerm, J. P. Guillerm et alii (1983), Le miroir des femmes I. Moralistes et polémistes au XVIe siècle. Lille.

F. R. Hausmann (1974), "Campano, Giovanni Antonio", in Dizionario biografico degli italiani. 17. Roma, 424-429.

J. IJSEwijn (1973), "Le latin des humanistes français. Évolution et étude comparative", in Humanisme français au début de la Renaissance (Colloque international de Tours, XIV e stage). Paris: 329-342.

W. Jaeger ( $\left.{ }^{3} 1954\right)$, Paideia I. Berlin.

L. Jardine (1988), "Distinctive disciplina: Rudolph Agrícola's influence on methodical thinking in the humanities", in Rudolphus Agricola Phrisius (1444-1485). Proccedings of the International Conference at the University of Groningen (28-30 October 1985). F. Akkerman and A. J. Vvanderjagt (ed.). Leiden: 38-57.

C. P. Jones (1971), Plutarch and Rome. Oxford.

P. Kessel (1969), Les gauchistes de 89. Paris.

P. O. Kristeller (1955), The Classics and Renaissance thought. Cambridge-Massachusetts.

- (1962), "Umanesino filosofico e umanesino letterario", Lettere Italiane 14: 392 sqq.

A. Luís: Antonii Lodouicimediciolyssipponensis Problematum libri quinque opus absolutum, et facundum, et uarium, multiingaque eruditione refertissimum, Olyssipone, M. D. XXXIX (Manuel Chaves de Andrade, As três 
primeiras Seç̧ôes do Primeiro Livro dos Problemas de António Luis, Coimbra, Faculdade de Letras, 1995: texto dactilografado).

J. A. Maravall (1964), El mundo social de «La Celestina». Madrid.

J.-C. Margolin (1966), Declamatio de pueris statim ac liberaliter instituendis. Étude critique, traduction et commentaire. Genève.

R. Marnoto (1996), A "Arcadia» de Sannazaro e o bucolismo. Coimbra.

H.-I. Marrou ( $\left.{ }^{6} 1965\right)$, Histoire de l'éducation dans l'Antiquité. Paris.

M. Martelli (1988), "Firenze", in A. Asor Rosa (dir.), Letteratura italiana. Storia e geografia. 2. L'età moderna. 1. Torino, 25-201.

G. Martellotti (1983), "Osservazioni sul carattere orale del primo insegnamento del greco nell'Italia umanistica", in Dante e Boccaccio e altri scrittori dall'Umanesimo al Romanticismo. Con una premessa di Umberto Bosco. Firenze, 241-248.

G. Martellotti, M. Feo (1983), "Di un frammento omerico inesistente e del testo di una lettera petrarchesca", Scritti petrarcheschi, A cura di Michele Feo e Silvia Rizzo, Padova, 579-592.

M. Martins (1983), "A amizade e o amor conjugal no "Leal conselheiro", in Estudos de cultura medieval, Lisboa: 187-206. 
C. Maurício (2005), A Invenção de Oliveira Martins. Politica, Historiografia e Identidade Nacional no Portugal Contemporâneo (1867-1960). Lisboa.

A. Michel (1984), "Le Credo de Guillaume Budé: rhétorique et philosophie dans le De transitu", in Mélanges sur la littérature de la Renaissance à la mémoire de V.- L. Saulnier. Genève: 19-29.

P. Mesnard (1977), L'essor de la philosophie politique au XVIe siècle. Paris.

A. Momigliano (1991), La naissance de la Biographie en Grèce Ancienne. Strasbourg.

O. P. Monteiro (1971), A Formação de Almeida Garrett. Experiência e Criação. Coimbra.

H. Moreira (1552), Oração de sapiência de Hilário Moreira por Albino de Almeida Matos (1990). Coimbra.

T. Moro: L'Utopie de Thomas More (1978), Présentation, texte original, apparat critique, exégèse, traduction et notes par André Prévost. Préface de Maurice Schumann. Paris.

R. Naudeau (1952), "The Progymnasmata of Aphthonius in translation”, in Speech monographs, 19: 264-285.

E. A. De Nebrija (1509), De liberis educandis libellus in Léon Esteban y Laureano Robles ed. (1981), La educación de los hijos. Estudio, edición, traducción y notas. Valencia.

H.T. Parker (1937), The Cult of Antiquity and the French Revolutionaries. Chicago. 
I. D. Pedro e F. J. Verba, Livro da Vertuosa benfeytoria. Ed. Crítica, introdução e notas de Adelino de Almeida Calado (1999). Coimbra [cit. VB].

L. Pernot (1983), "Chance et destin dans la rhétorique épidictique grecque à l'époque impériale", in F. Jouan (ed.), Visages du destin dans ls mythologies: Mélanges Jacqueline Duchemin (Actes du Colloque de Chantilly 1'r-2 mai, 1980). Paris, 121-9.

C. Pelling (2002), "Plutarch's method of work in the Roman Lives" in Plutarch and History. Wales.

J. C. Pimpão (1989): Prefácio à edição de Os Lusiadas, Lisboa.

Frei H. Pinto (1952) Imagem da vida cristã, com prefácio e notas de P.e M. Alves Correia.

D. Placido (1995), "La Demokratía de Plutarco", in I. Gallo \& B. Scardigli (eds.), Teoria e Prassi Politica nelle Opere di Plutarco. Napoli, 131-138.

G. Pontiggia (1998), I contemporanei del futuro. Milano.

A. Quondam (1993), "Introduzione”, S. Guazzo, La civil conversazione. Modena, Ferrara, VII-LXXVIII.

F. Rabelais (1959), Pantagruel. Texte établi et présenté par Jean Plattard. Paris, cap. VIII: 42.

G. Ragone (1983), "La letteratura e il consumo: un profilo dei generi e dei modelli nell'editoria italiana”, in A. Asor Rosa (dir.), Letteratura italiana. 2. Produzione e consumo. Torino, 741-742. 
A. C. Ramalho (1986): "João de Barros e Erasmo: a propósito da Viciosa Vergonha" (Notas de investigação' - XXVI), Humanitas 37-38: 275-280.

- (1998 e 2000), Para a história do Humanismo em Portugal III e IV. Lisboa.

A. Redondo (1976), Antonio de Guevara (1480?-1545) et l' Espagne de son temps. (De la carrière officielle aux oeuvres politico-morales). Genève.

G. Rohlfs (1969), Grammatica storica della lingua italiana e dei suoi dialetti, Torino, 3 vol.

J. De Romilly (1979), La douceur dans la pensée grecque. Paris.

J. Sadoleto, Traité d'éducation du Cardinal Sadolet et vie de l'auteur par Antoine Florebelli. Traduit pour la première fois avec texte latin, notes explicatives et justificatives par P. Charpenne (1855). Paris.

O. Sauvage (1970), Luisa Sigeia. Dialogue de deux jeunes filles sur la vie de retraite (1552). Présenté, traduit et annoté. Paris.

B. Scardigli, ed. (1995), Essays on Plutarch's Lives. Oxford.

C. Scarpati (1987), Dire la verità al principe. Ricerche sulla letteratura del Rinascimento. Milano, 11-44.

O. Schottenloher (1972), "Érasme et la «Respublica Christiana»", in Colloquia Erasmiana Turonensia, vol. II. Paris: 667-690. 
L. A. SÉnecA, Cartas a Lucílio. Tradução, prefácio e notas de J. A. Segurado e Campos (1991). Lisboa.

M. Simondon (1982), La mémoire et l'oubli dans la pensée grècque jusq'à la fin du Ve siècle avant J.- C. Paris.

N. N. C. Soares (1993), "A literatura de sentenças no Humanismo Português: res et uerba”, in Actas do Congresso internacional Humanismo Português na época dos Descobrimentos (Coimbra 9-12 de Outubro de 1991). Coimbra; e in Humanitas 43-44 (19911992): 377-410.

- (1993a), "A Virtuosa Benfeitoria, o primeiro tratado de educação de príncipes em português”, Biblos 69 - Actas do Congresso Comemorativo do $6^{\circ}$ Centenário do Infante D. Pedro (Coimbra, de 25 a 27 de Novembro de 1992). Coimbra: 289-314.

— (1994), O príncipe ideal no século XVI e a obra de D. Jerónimo Osório. Coimbra.

_ (2002), “A Historiografia do Renascimento em Portugal: referentes estéticos e ideológicos humanistas", in Luís F. R. Thomaz (ed.), Aquém e Além da Taprobana. Estudos Luso-Orientais à memória de Jean Aubin e Denys Lombard. Lisboa.

__ (2002a) "Cataldo e Resende: da pedagogia humanista de Quatrocentos à influência de Erasmo", in Cataldo $e$ Resende. Actas do Congresso Internacional do Humanismo Português (Coimbra-Lisboa-Évora, 25 a 28 de Outubro de 2000). Lisboa.

S. Swain (1989), "Plutarch's De fortuna Romanorum”, 


\section{CQ39.2 504-516.}

- (1998r), Hellenism and Empire: language, classicism, and power in the Greek world, AD 50-250. Oxford.

H. A. TAIne (1892), Les origines de la France contemporaine. La Révolution. III-Le gouvernement révolutionnaire. Paris.

J. P. Tavares (1963), Obras Portuguesas de André de Resende. Lisboa.

D. de Teive (1786), Epodos que contém Sentenças úteis a todos os homens, às quais se acrescentam Regras para a boa educação de um Principe. Composto tudo na Lingua Latina pelo insigne português Diogo de Teive. Traduzido no vulgar em verso solto por Francisco de Andrade. Copiado fielmente da ediçâo de Lisboa de 1565. Lisboa.

É. V. Telle (1954), Érasme de Rotterdam et le septième sacrement. Étude d'évangélisme matrimonial au XVIe. siècle et contribution à la biographie intellectuelle d'Érasme. Genève.

E. Valgiglio (1987), "Iotopía e Bíos in Plutarco», Orpheus ns. 8 50-70.

J. F. de Vasconcelos, Comédia Eufrosina. Texto de la edicion principe de 1555 con las variantes de 1561 y 1566. Ed. Eugenio Asensio (1951). Madrid.

P. P. Vergerio (1918), De ingenuis moribus et liberalibus studiis adulescentiae. Ed. A. Gnesotto. Padova.

P. Villey (1912), Les sources d'idées. Paris. 
F. A. Yates (1975), L'art de la mémoire, trad. de l'anglais par Daniel Arasse. Paris.

R. WeIss (1977), Medieval and Humanist Greek. Padova

D. Wittenbach (1820), Animadversiones in Plutarchi. Opera Moralia. Leipzig.

M. Zancan (1988), "Venezia e il Veneto", in A. Asor Rosa (dir.), Letteratura Italiana. Storia e geografia. 2. L'età moderna. 1, Torino, 619-741. 


\section{COLECÇÃo AUtores \\ GREgos E LATINos - SÉrIe ENSAIOS}

1. Carmen Soares, José Ribeiro Ferreira e Maria do Céu Fialho: Ética e Paideia em Plutarco (Coimbra, $\mathrm{CECH}, 2008)$.

2. Joaquim Pinheiro, José Ribeiro Ferreira, Nair Castro Soares, Rita Marnoto: Caminhos de Plutarco na Europa (Coimbra, CECH, 2011). 2a edição, revista e com um novo estudo.

3. Cláudia Teixeira, Delfim F. Leão and Paulo Sérgio Ferreira: The Satyricon of Petronius: Genre, Wandering and Style (Coimbra, CECH, 2008).

4. Teresa Carvalho, Carlos A. Martins de Jesus: Fragmentos de um Fascinio. Sete ensaios sobre a poesia de José Jorge Letria (Coimbra, CECH, 2009).

5. Delfim Ferreira Leão, José Ribeiro Ferreira e Maria do Céu Fialho: Cidadania e Paideia na Grécia Antiga (Coimbra, CECH, 2010).

6. Maria de Fátima Silva and Susana Hora Marques: Tragic Heroines on Ancient and Modern Stage (Coimbra, $\mathrm{CECH}, 2010)$.

7. Ália Rosa Rodrigues, Carlos A. Martins de Jesus, Rodolfo Lopes: Intervenientes, Discussão e Entretenimento, No Banquete de Plutarco (Coimbra, CECH, 2010). 
8. Luísa de Nazaré Ferreira, Paulo Simóes Rodrigues e Nuno Simóes Rodrigues: Plutarco e as Artes. Pintura, Cinema e Artes Decorativas (Coimbra, CECH, 2010). 
IMPRESSÃO:

Simốes \& Linhares, Lda.

Av. Fernando Namora, n. ${ }^{\circ} 83$ - Loja 4

3000 CoImbra 


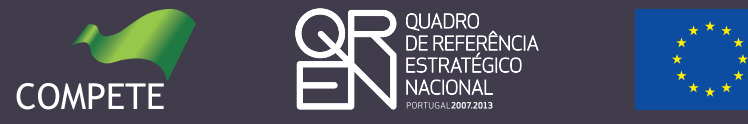